د/ بثينة عبد الله الملا

\title{
دور مواقع التواصل الاجتماعي في تحقيق أهداف التربية القنية والاتجاهات نحوها لاى طلاب المرحلة الثانوية
}

إعداد

\author{
د/ بثينة عبد الله الملا

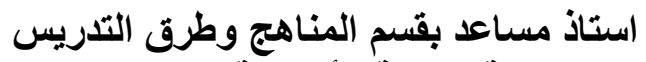 \\ كلية التربية الأساسية بالكويت وطنيت
}

\section{المستخلص}

سـعى البحث الحسالي للتعرف على دور مواقع التو اصـل الاجتمـاعي في تحقيتق

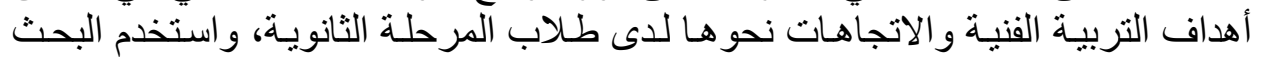

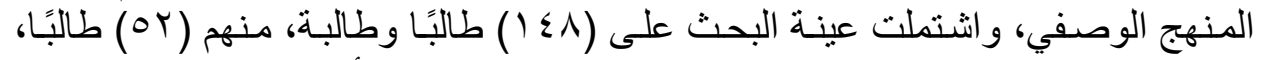

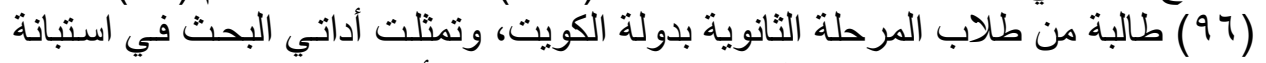

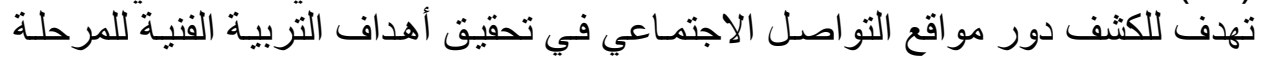

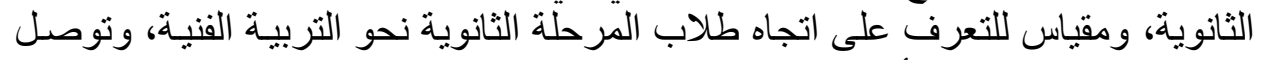

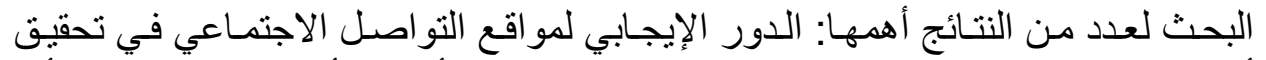

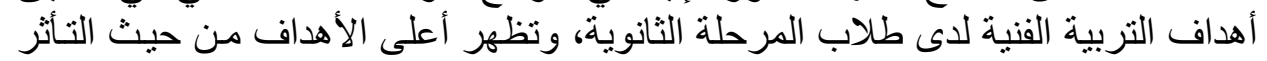

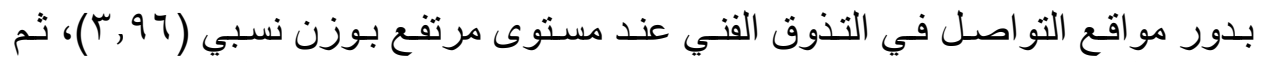

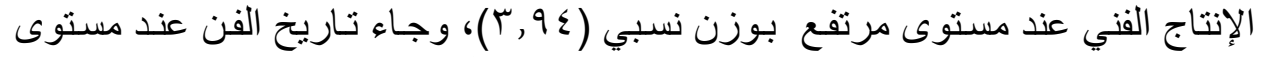

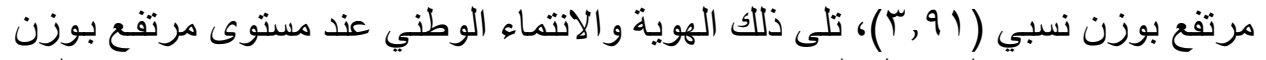

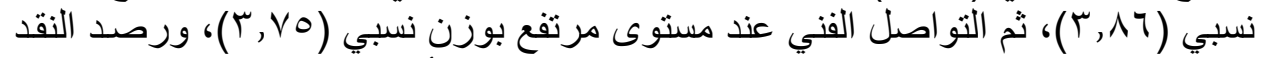

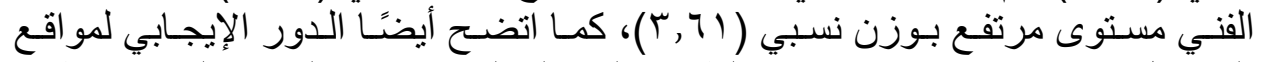

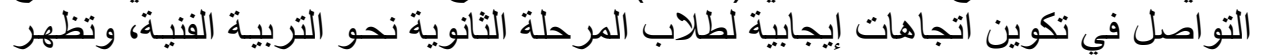
أعلى المحاور من حيث التأثر بدور ها في تذوق محتوى مـادة التربيـة الفنيـة عند مستوى

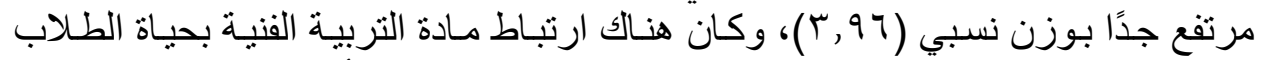

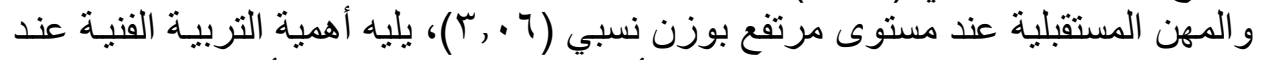

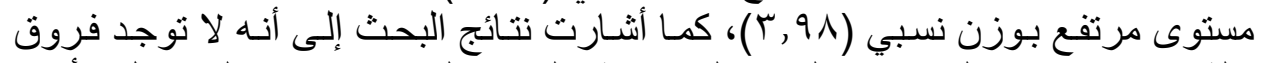

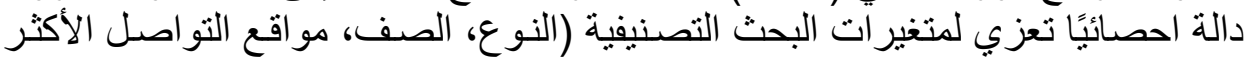

(ستخدامًا).

الكلمات المفتاحية: (مواقع التواصل الاجتماعي ـ أهداف التربية الفنية ـ الاتجاهات ـ

المرحلة الثانوبية)

العدد الخامس والاربعون (الجزء الثانى) ا ب r r

(473)

مجلة كلية التربية- جامعة عين شمس 


\title{
The Role of Social Media Websites in Achieving the Goals of Art Education among Secondary School Students and Their Attitudes towards It
}

\author{
By \\ Dr. Bothainah A. T. M. Almulla \\ Associate professor of curriculum \& instruction, \\ Basic Education College, Kuwait
}

\begin{abstract}
:
This study aimed to explore the role of social media websites in achieving the goals of art education among secondary school students and their attitudes towards it. The study adopted the descriptive research method. The participants comprised (148) students (52 male and 96 female students) among the secondary school students in Kuwait. The study utilized a questionnaire of the role of social media websites in achieving art education goals in the secondary stage and an attitude scale towards art education among the study participants. The results revealed the positive role of social media in achieving the goals of art education. The highest goals in terms of being affected by the role of social media were in art appreciation that appears at a high level with a relative weight of (3.96), followed by artistic production at a high level with a relative weight of (3.94), art history at a high level with a relative weight of (3.91), identity and national affiliation at a high level with a relative weight of (3.86), artistic communication at a high level with a relative weight of (3.75), and artistic criticism at a high level with a relative weight of (3.61), respectively. It was also clear that the positive role of social media in secondary school students' attitudes towards art education. The results revealed that social media has highly affected students' attitudes towards content of art education appreciation at a very high level with a relative weight of (3.96), followed by the connection of art education to the students' life and future professions at a high level with a relative weight of (3.06), the importance of art education at a high level with a relative weight of (3.98), respectively. The results also indicated that there were no statistically significant differences attributed to the categorical research variables (gender, grade, and most commonly used social media websites).
\end{abstract}

Keywords: (Social Media Websites - Goals of Art Education - Attitudes Secondary Stage).

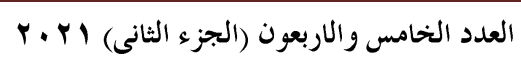

(474)

مجلة كلية التربية- جامعة عين شمس 
د/ بثينة عبد الله الملا

\title{
دور مواقع التواصل الاجتماعي في تحقيق أهداف التربية القنية والاتجاهات نحوها لاى طلاب المرحلة الثانوية
}

إعداد

\author{
دا بثينة عبد الله الملا

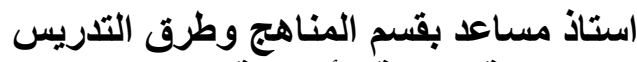

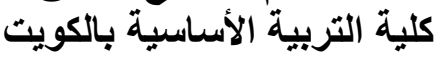

المقدمة:

يتميز العصر الذي نعيش فيه بالتسار ع التقني الذي يعبر عن مدى التطور الهائل

و المتلاحق في مجال الاتصالات؛ وقد أدى هذا التطور إلى إحداث ثورة حقيقبـة وتغيرات جو هرية في شتى مجـالات الحياة السياسية، و الاجتماعية، و التعليمية، و الصناعية، ليس على المسـتوى المحلـي فقط، و إنمـا علـى المسـتوى العـالمي؛ نتيجــة تضــاعف أعـداد المستخدمين لثبكة الانترنت في جميع أنحاء العالم.

وتعد مواقع التواصـل الاجتمـاعي من أحد أهم مظـاهر التفاعل في إطسار ثورة

التكنولوجيا الحديثة للاتصالات، وقد بدأ استخدام مو اقع التواصل الاجتماعي في الو لايـات المتحــدة الأمريكيـة وبعـد ذلــك بـدأت بالانتشــار و التوسـع فـي أنحــاء العـالم، وذكـرت الإحصاءات أن 7\%\% من سكان العالم العربي والإسلامي من الفئة العمريـة ب ـ ـ (سنة يستعمل • ^^\% منهم الانترنت ومواقع التواصـل الاجتمـاعي؛ حيث تعكس النسب تزايدًا ملحوظًا في عدد المسـتخدمين بجانـب عدد السـاعات التـي يقضـونها أمسام هذه المواقع

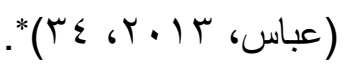

ويمارس من خلالها المستخدمون كل الأنشطة التفاعليـة والتشـاركية بكل حريـة، فلم تعد تقتصر على كونها أدوات اتصال وتبادل وتسلية بين الافر اد والمجتمعات عبر مـا

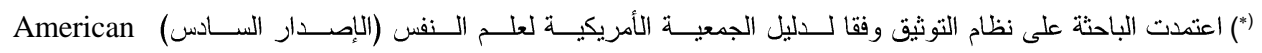
.Psychological Association (APA-6)

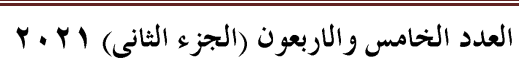

(475)

مجلة كلية التربية- جامعة عين شمس 
دور مو اقع التو اصل الاجتماعي في تحقيق أهداف التربية الفنية والاتجاهات نحوها لاى طلاب المرحلة الثانوية

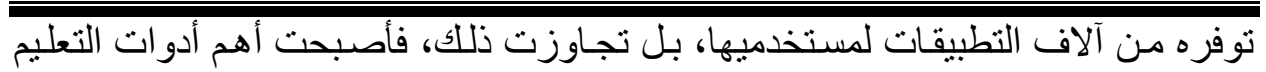
و التعلم بما توفره من خصائص تتيح التعليق ومشـاركة الملفات ومقاطع الفيديو والصـور

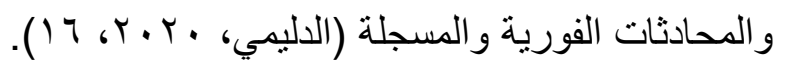
ويتصدر مواقع التواصل الاجتماعي ثلاثة مواقع مهمة في عمليات التعليم و التعلم من خلال تبادل النصوص و الصسور و الرسوم والفيديو هات، و غيرهـا تتمثل في تويتر و هو منصة للتندوين المصغر، وواتس أب تطبيق للتراسل الفوري عبر الهواتف الذكيـة ويقدم وسـيلة للحفـاظ على العلاقـات الاجتماعيـة وتوطيـدها ويـوفر العديـد مـن التسـهيلات للمستخدمين للتو اصـل مـع بعضـهم البعض بتبـادل الرسـائل و الملفـات النصـة و الصور و الفيديوهات، وانستجر ام، وهو من أفضل مواقع التو اصل الاجتماعي التي تمنح المستخدمين فرصـة التفاعل مـع الأصـدقاء، عبر نشـر التعليقات على الصـور ومقاطع مهرع الفيديو، وتتميز هذه المو اقع بإيصال الرسائل النصية والصـور وملفـات الصـوت والفيديو

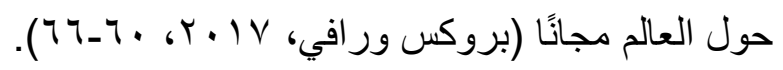
ونتيجة للواقع الذي نعيشه في ظل الجائحة الناتجة عن فيروس كورونـا المستجد (COVID-19)، وانتقال التعليم من صورته التقليدية وجهًا لوجـه في الفصول الدراسية إلى التعليم عن بعد في الفصول الافتراضية سواء بالصورة التزامنيـة أو غير التزامنية متخذًا من مو اقع التواصل المختلفة والمتنوعة وسيلة دراسية للتو اصل الفعال بين المعلم وطلابه من خـلال قنوات الاتصـال ومنتديات الدردشـة ومجمو عات العمل التعاونية بمـا توفره هذه المو اقع من إمكانيات لمشـاركة ملفات النصوص و الفيديو و الصور والرسوم و التعليقات لتحقيت الأهداف التربويـة بشكل عـام و التدريسية لكل مـادة در اسية بشكل خاص. وتعد التربية الفنية إحدى المواد الدر اسية التي تدرس في جميع مر احل التعليم قبل الجامعي، والتي ترتبط بوجـه عـام بمواقع التواصل الاجتماعيـة، وتهدف إلى تحقيق النمو الفني للمتعلمين في إطـار ديننا الإسـلامي الحنيف، وتوحيد روح الانتماء الوطني لروتي 
و الاجتماعي، و اكتسابهم الخبرات و المعلومات و الحقائق الفنية التي تنمي لديهم الجوانب المبل الابتكاريـة التعبيريـة، وتثري و عيهم الفني لتذوق القيم الجماليـة، وتعـرفهم بتـاريخ فـن الحضـار ات و الثــوب المختلفـة، مـع تتميـة قدر اتهم على النقد الفنـي باسـتخدام التفكير النقدي، وابـاء الر أي في تحليـل الأعمـال الفنيـة، وتحقيق التواصـل الفنـي عن طريـق المساهمة والمشاركة في المعارض و المسابقات الفنيـة الداخليـة والخارجيـة (التوجيـه العام

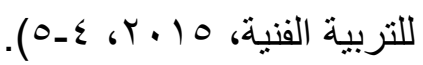
وفي هذا الاتجـاه أثنـار إنريكيز (Enriquez, 2014, 12) أنه لوحظ بـأن مواقع التو اصل الاجتمـاعي ومنهـا تويتر Twitter، فيس بوك Facebook، جوجل

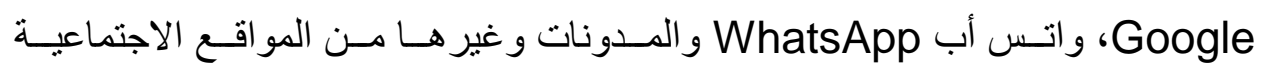
الأخرى قد تزايد استخدامها في الغرف الصفية؛ حيث أن العديد من المعلمين وأعضـاء هيئة التدريس في المؤسسات التعليمية يستخدمونها للاستفادة منها في المساعدة في تحقيق أهداف دروسهم التعليمية. ويؤكد ذلك ما أشتارت إليها الدراسات التربوية في مجال التربيـة الفنية من تعدد

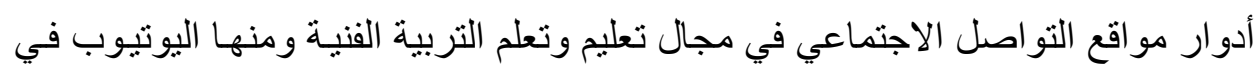

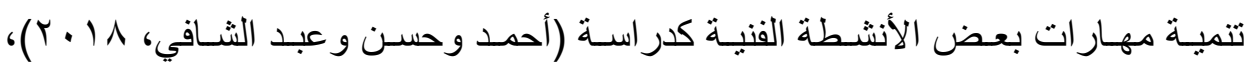
واستخدام أدوات جوجل التعليميـة في دعم مهار ات التواصل في التربيـة الفنيـة كدر اسـة

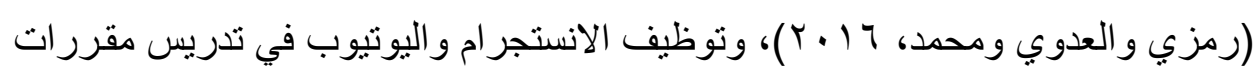

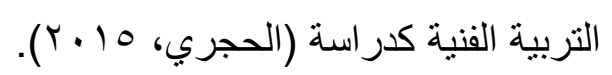

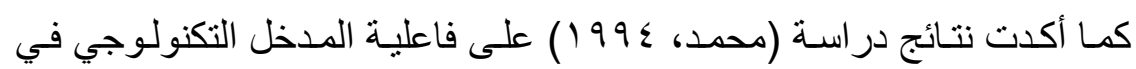
تحقيق بعض أهداف التربية الفنية، ومنها التعبير الفني عن المشـاعر والاحاسبس الفنية، و التعبير الإبداعي الذي يعكس قدرة الطالب على استدعاء أكبر قدرًا من الأفكار المناسبة وهن في فترة زمنية محددة، وإنتاجه لعملِ فني له قيمة، ووظيفة نفعية في الحياة اليومية. 
دور مواقع التواصل الاجتماعي في تحقيق أهداف التربية الفنية والاتجاهات نحوها لاى طلاب المرحلة الثانوية

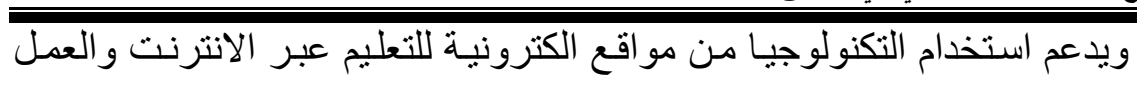
في مجموعـات تتميـة مهـار ات الثقافـة الرقميـة و الإنتـاج الفتـي والاتجـاه نحـو اسـتخدام التكنولوجيا في الإنتاج الفني بالإضـافة إلى تكون حالـة من الاستعداد و التهيئة النفسية

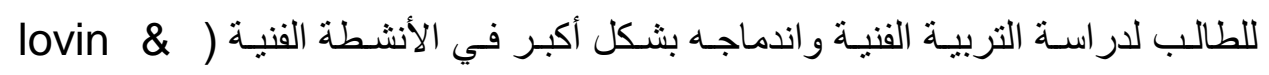
.(lambeith, 2015, 15

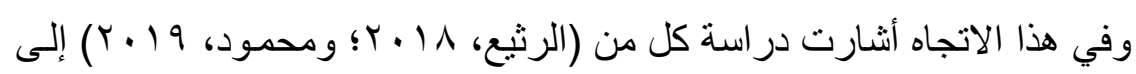
فاعلية استخدام المواقع التكنولوجية عبر شبكة الانترنت في تدريس التربيـة الفنية لتنمية

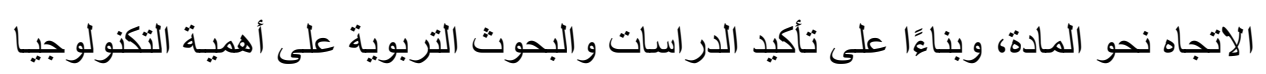
بصفة عامة ومو اقع التو اصل بصفة خاصة في تدريس التربية الفنية وتنميـة مهار اتها من تعبير فني وابداعي، وتصوير نتكيلي و إنتاج عملً فني له قيمة وظيفية في الحياة العامـة،

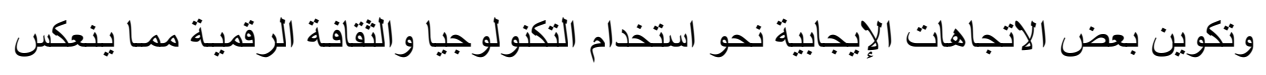

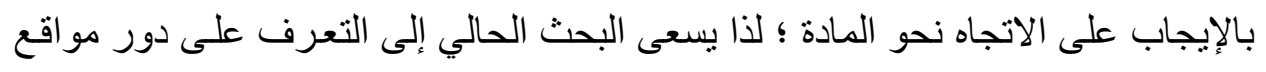

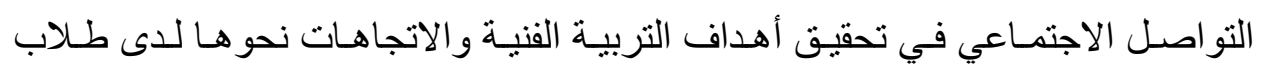
المرحلة الثانوية من وجهة نظر هم.

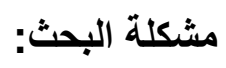

نظرًا للتفاعل العـالمي مـع مو اقع التواصل الاجتمـاعي، ومن ثم تأثثر هـا البـالغ

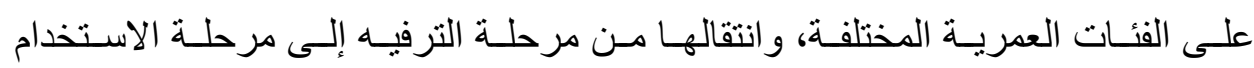

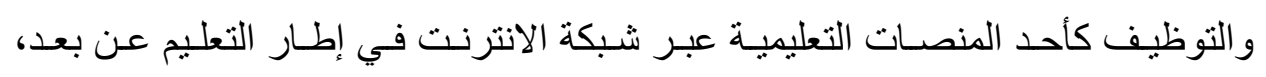
وللتغلب على الصعوبات التي تواجه الطلاب لاستكمال در استهم بصورتها التقليديـة وجهًا لوجـه، و الاعتمـاد على التعليم الالكترونسي بصورة كلية في زمن الأوبئسة ومنهـا انتشـار

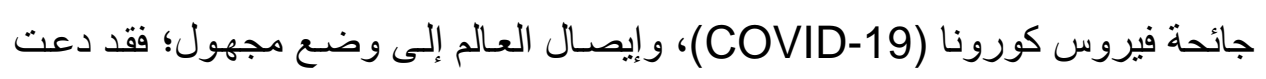
الحاجـة للتعرف على دور مو اقع التواصل الاجتمـاعي في تحقيق أهداف التربيـة الفنيـة و الاتجاهات نحو ها لدى طلاب المرحلة الثانوية. 
د/ بثينة عبد الله الملا

ومما يدعم ذلك نتائج بعض الدراسات التربوية التي أكدت بعض أدوار التعليم

الالكتروني ومو اقعه عبر شبكة الانترنت في تدريس التربية الفنية وتتمية مهار ات طلابها

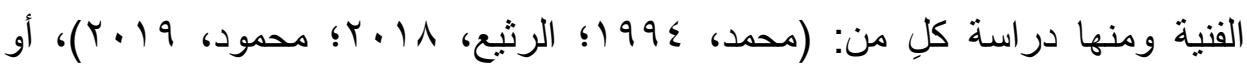
استخدام مواقع التواصل الاجتماعي تويتر وفيسبوك والواتس أب، والويكي واليوتيوب

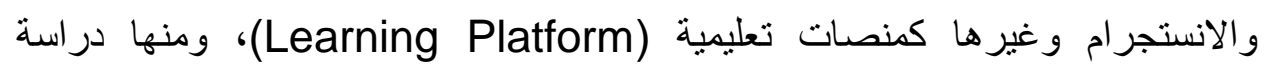

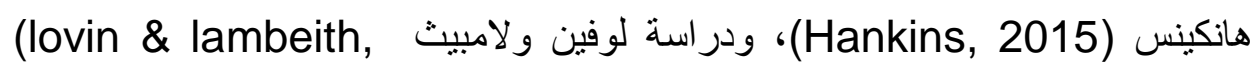

وفي ضـوء نتـائج الدراسـات والبحوث السـابقة التـي أكدت على تحقيق بعض

النجاحات عند استخدام مواقع التو اصل الاجتماعي في عملية التعليم، وفي تسـيل عملية التو اصـل بين المعلم وطلابـه وتسـهيل نقل الدروس و التعليمـات ومنهـا در اسـة كلِ مـن:

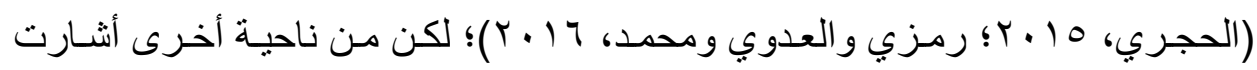
بعض الدر اسات إلى وجود بعض القصور ومنها صعوبة تبادل الملفات الكبيرة، وكذلك التبادل غير الآمن للمعلومات (Laughton, 2011). كما أثنارت بعض المؤتمر ات الدوليـة إلى أهميـة الاستفادة من مواقع التواصل

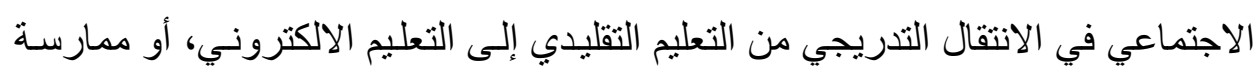

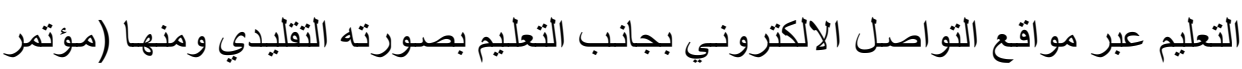

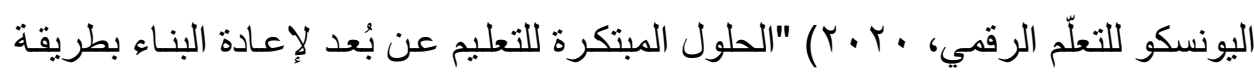

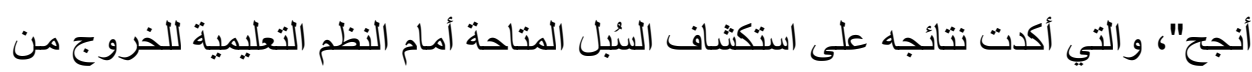
الأزمـة أكثر قوّة و عزيمـة، ولمواجهـة الاضـطر ابات المستقبلية مـن خـلال تكوين بيئة

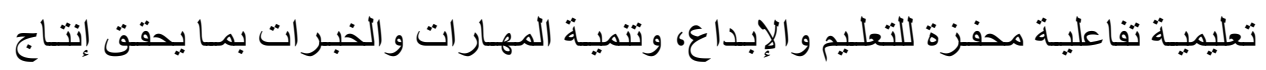

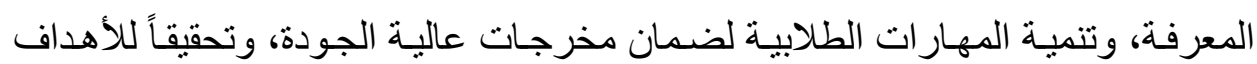
التربوية المتتوعة، وتكوين ميول و اتجاهات إيجابية نحوه، وبالتالي نحو المواد الدراسية. 
دور مواقع التو اصل الاجتماعي في تحقيق أهداف التربية الفنية والاتجاهات نحوها لاى طلاب المرحلة الثانوية

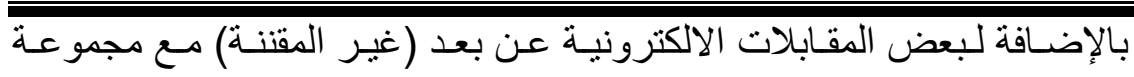
عشوائية من طلاب التربية الفنية بالمرحلة الثانويـة بدولة الكويت، و التي أكدت نتائجها

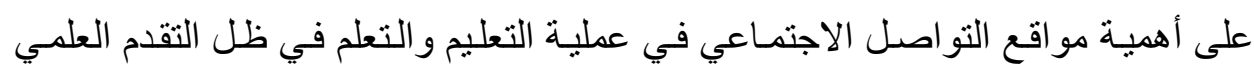
و التكنولوجي لمو اقع التو اصل وللتغلب على بعض المشكلات التي تواجه التعليم بصورته

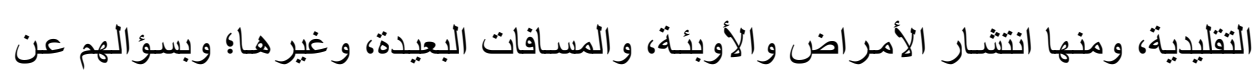

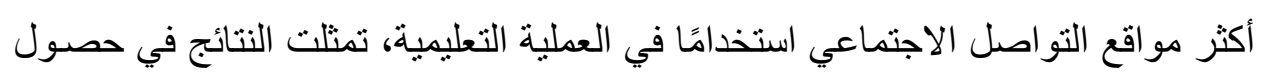

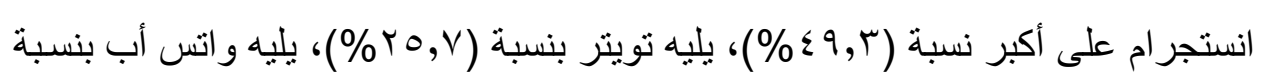

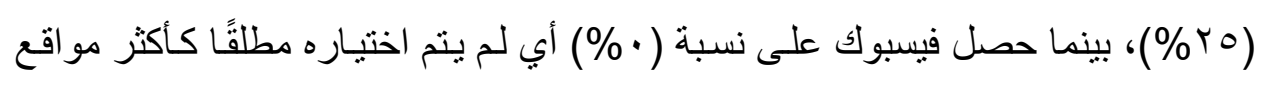
التو اصل استخدامًا.

و انطلاقًا مـن هذه الحقـائق التـي تفرضـهـا علينـا شـبكات التو اصـل الاجتمـاعي

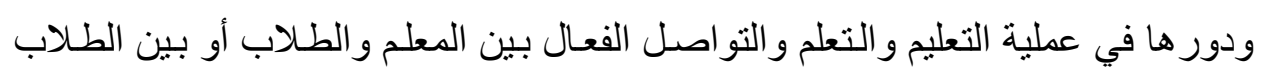

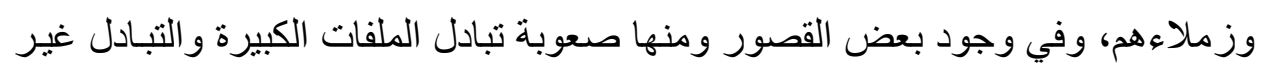

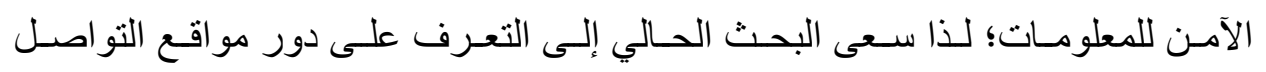

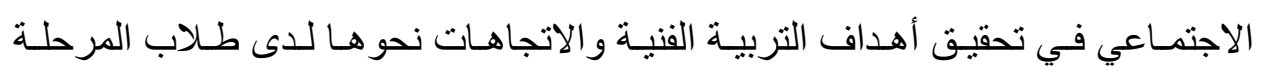
الثانوية من وجهة نظر هم، من خلال السؤال الرئيس التالي:

ما دور مواقع التواصل الاجتماعي في تحقيق أهداف التربية الفنية والاتجاهـات

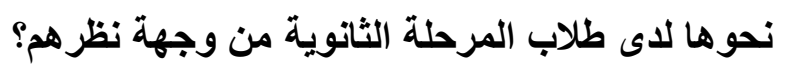
ويتفرع عن هذا السؤال الرئيس الأسئلة الفرعية التالية:

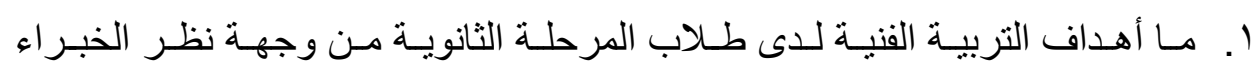

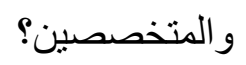
Y. ما دور مواقع التواصل الاجتماعي في تحقيق أهداف التربية الفنية من وجهة نظر

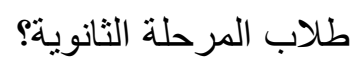


د/ بثينة عبد الله الملا

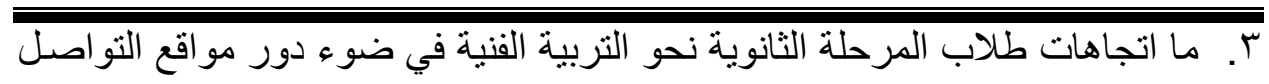

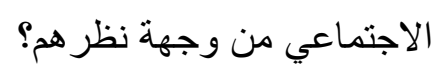

ع. . مـا مدى اختلاف استجابات عينـة البحث نحو دور مو اقع التو اصـل الاجتمـاعي في

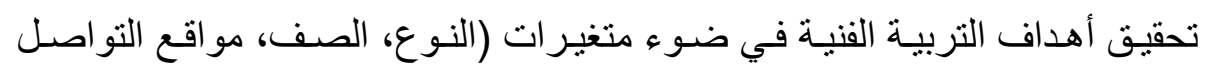
الأكثر استخدامًا)؟

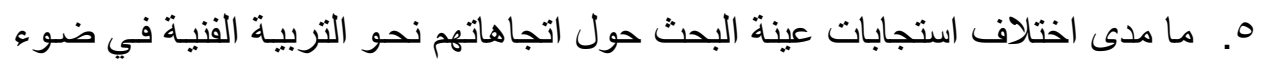
دور مو اقع التواصل الاجتمـاعي تعزي لمتغيرات (النوع، الصف، مواقع التواصل

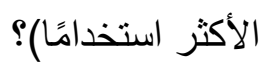

\section{أهداف البحث:}

سعى البحث الحالي إلى تحقيق ما يلي:

ا . . وضع إطار فكري يشمل متغيرات البحث وطبيعة عينته. r. الكثف عن أهداف التربية الفنية لدى طلاب المرحلة الثانوية من وجهة نظر الخبراء و المتخصصين. r. التعرف على دور مو اقع التواصل الاجتمـاعي في تحقيق أهداف التربيـة الفنيـة من وجهة نظر طلاب المرحلة الثانوية.

ع. التعرف على اتجاهـات طلاب المرحلـة الثانويـة نحـو التربيـة الفنيـة في ضـوء دور مواقع التو اصل الاجتماعي. ๑. تحديد ما إذا كانت هناك فروقًا بين استجابات عينة البحث من طلاب المرحلة الثانويـة

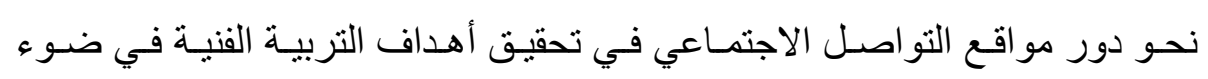
متغيرات (النوع، الصف، مواقع التواصل الأكثر استخدامًا).

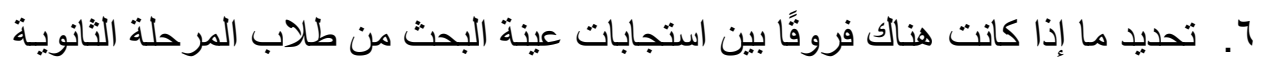

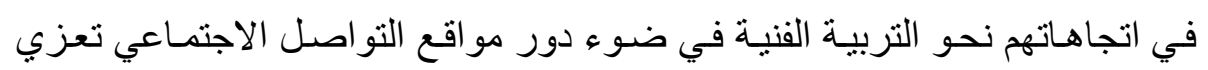
لمتغيرات (النوع، الصف، مواقع التواصل الأكثر استخداماً). 
قد تفيد نتائج البحث الحالي الفئات التالية:

- الطلاب: وتتمثل في تحسين دور مواقع التواصل الاجتمـاعي (تويتر - و واتس أب انستجر ام) في تحقيق أهداف التربية الفنية والاتجاهات نحوها لدولى لـولابها. - - القائمين على العملية التعليمية: توجيه نظر المسؤولين بالتعليم العام على دور مواقع التو اصل الاجتماعي في تحقيق أهداف التربية الفنية والاتجاهات نحو ها. - مصـمي المنـاهج: إعـادة النظـر في تنظيم محتوى مـادة التربيـة الفنيـة بالمر احل

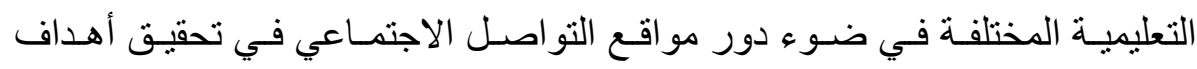
التربية الفنية والاتجاهات نحو ها لدى طلابها. - - طلاب المرحلة الثانوية: توفير مو اقع المتابعة والتوجيه و التقييم في ضوء التعليم عن بعد عبر المنصات الرقمية. - مطوري التعليم: تحسين وتطوير دور التقنيات ومنها مو اقع التواصل الاجتمـاعي في تحقيق أهداف التربية الفنية والاتجاه نحو ها. - - البـاحثُن: وذلك بتقديم أداتين أحدهما استبانة دور مواقع التواصل الاجتمـاعي في

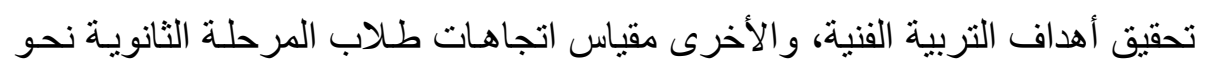
التربية الفنية في ضوء دور مواقع التواصل الاجتماعي. - الإذعان لتوصيات البحوث و الدراسات والأدبيات السابقة التي تنادي بصورة و اضحة بضـرورة الكثـف عن دور مو اقع التواصل الاجتمـاعي في تحقيق أهداف التربيـة الفنية والاتجاه نحو ها من وجهة نظر طلاب المرحلة الثانوية. 
اقتصر البحث على الحدود التالية: - الحدود الموضـوعية: تمثلت في دور مواقع التواصـل الاجتمــي في تحقيق

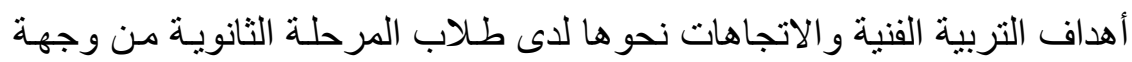

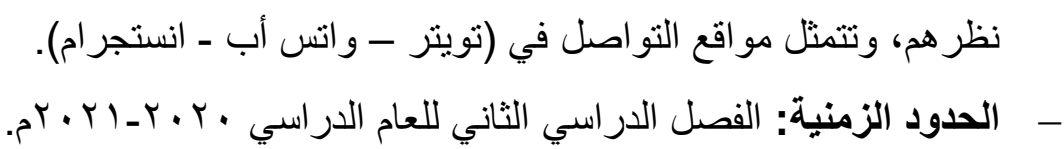

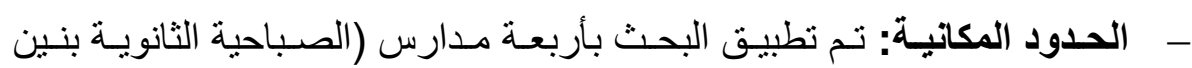

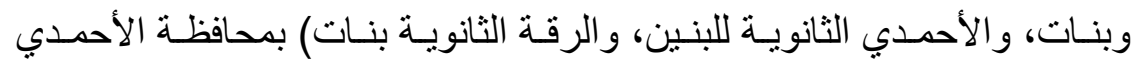
بدولة الكويت. - - الحدود البثرية: عينة عشو ائية من طلاب وطالبات الصفوف الثناثة بالمرحلة الثانوية بدولة الكويت.

\section{منهج البحث:}

لتحقيق أهداف البحث تم استخدام المنهج الوصفي التحليلي؛ للكثف عن دور

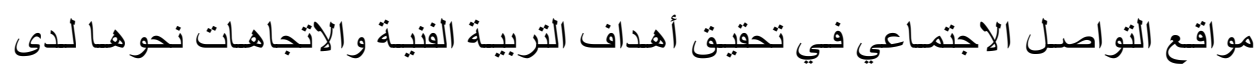

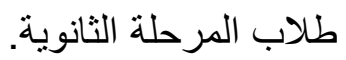

\section{أداتي البحث: - n (n)}

تمثلت أداتي البحث الحالي فيما يلي:

- - ماستبانة للكثف عن دور مواقع التو اصل الاجتمـاعي في تحقيق أهداف التربيـة الفنية للمرحلة الثانوية.

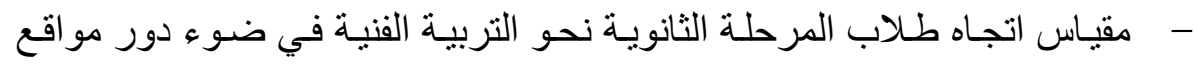

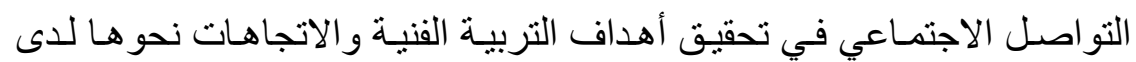
طلاب المرحلة الثانوية 
تضمنت مصطلحات البحث المفاهيم الأساسية التالية:

مواقع التواصل الاجتماعي:

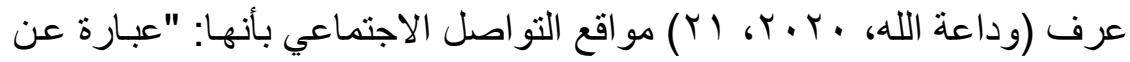
تطبيقات تكنولوجية مستندة إلى شبكة الانترنت تتيح التفاعل بين النـاس، وتسمح بنقل البيانـات الالكترونيـة وتبادلها بسـهولة، وتوفر للمستخدمين إمكانية العثور على آخرين يشتركون في نفس المصالح، وبناءاً عليه ينتج عن ذلك ما يسمى بالمجتمعات الافتر اضية Virtual Communities تشبه الكيانات الو اقعية".

ويعرفها البحث الحالي إجر ائيًا بأنها: "عبارة عن تطبيقات تكنولوجيـة معتمدة على شبكة شبكة الانترنت لتحقيق التواصل و التفاعل الالكتروني بين مختلف الفئات

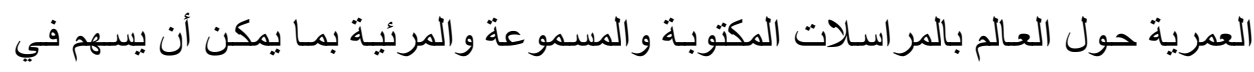
تحقيق أهداف التربية الفنية ويكون اتجاهات إيجابية نحوها لدى طلاب المرحلة الثانوية".

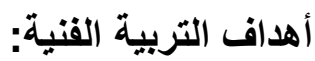

عرف (التوجيه الفني للتربيـة الفنيـة بالكويت، 10 ـ r، ) الأهداف التربويـة

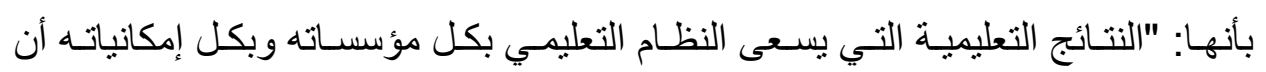

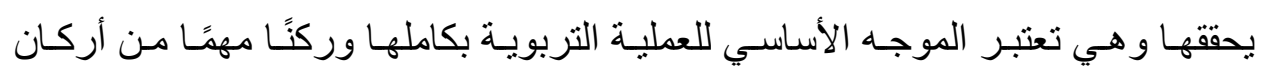

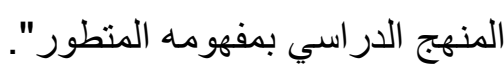

ويعرف البحث الحالي أهداف التربية الفنية إجر ائيًا بأنها: النتائج التعليميـة لمسادة

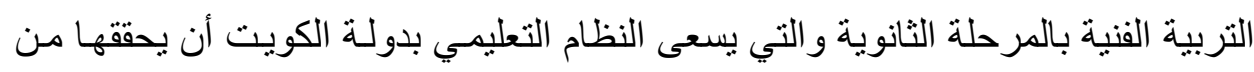

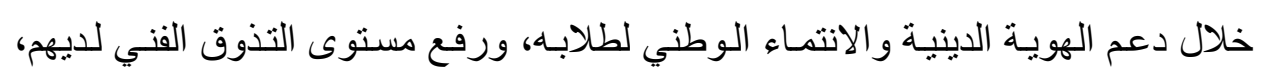

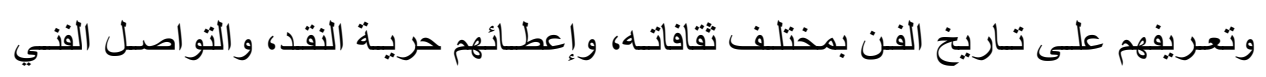


د/ بثينة عبد الله الملا

باستخدام شبكات التو اصل الالكترونيـة، وتقاس بالدرجـة التي يحصل عليها الطلبة على الملى الاستبانة المعدة لذلك.

\section{الاتجاه نحو التربية القنية:}

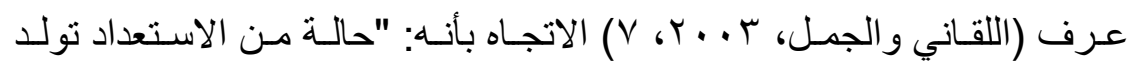
تأثثرًا ديناميكيًا على استجابة الفرد، وتساعده على اتخاذ القرار ات المناسبة، سواء أكانت بـاه بالرفض أم الإيجاب فيما يتعرض لله من مواقف ومشكلاته"

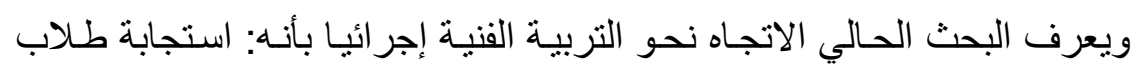

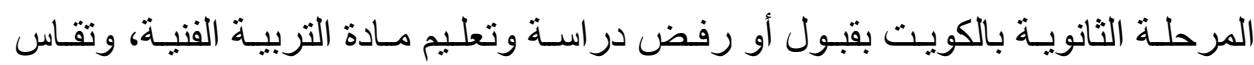
بالدرجة التي يحصل عليها الطلبة في مقياس الاتجاه نحو التربية الفنية.

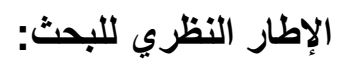

تنـاول الإطـار النظري متغيرات البحث في ثلاثـة محساور، الأول منهـا يتعلق بمو اقـع التو اصـل الاجتمـاعي، مـن حيـث: نشـأتها وماهيتهـا وخصـائصـها، و إيجابياتهـا، وسلبياتها، وبعض مو اقعها، بينما المحور الثاني يتعلق بأهداف التربيـة الفنبـة، من حيث: ماهيتها، وأهميتها، ومعايير ها، ومصادر ها، وأهداف التربية الفنية للمرحلة الثانويـة بدولـة الكويت، ويتعلق المحور الثالث بالاتجاه نحو التربية الفنبة، من حيث: ماهيته الاتجاه،

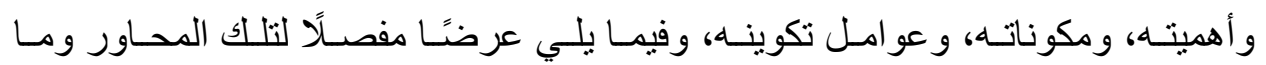
تتضمنه من موضو عات فر عية. 
دور مواقع التو اصل الاجتماعي في تحقيق أهداف التربية الفنية والاتجاهات نحوها لاى طلاب المرحلة الثانوية

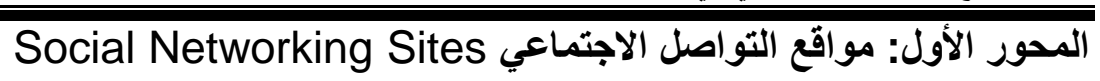
ظهرت مواقع التواصل الاجتمـاعي على شـبكة الانترنت منذ سنوات وتمكن مستخدميها من التواصل المرئي والصسوتي وتبـادل الصور و غيرهـا من الإمكانات التي توطلا العلاقة الاجتماعية بينهم، ويُطلق المصطلح على مجموعة من المو اقع الموجودة

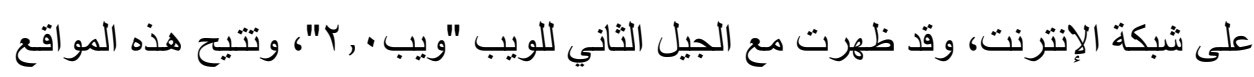

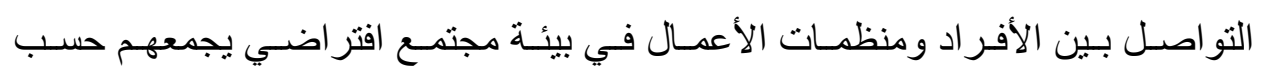

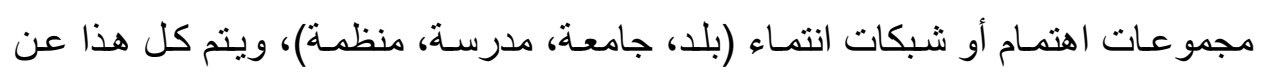
طريق خدمات التو اصل المباثر مثل إرسال الرسائل أو الاطلاع على الملفات الثخصية

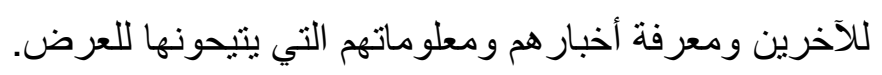

وفي هذا الاتجاه عرف شـارما وجوشي وشـارما \& Sharma, Joshi \&

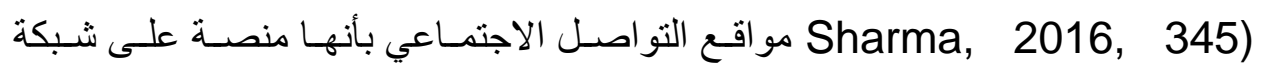

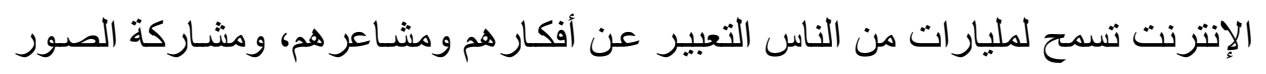
ومقاطع الفيديو و الانضمام إلى المجتمع الافتراضي.

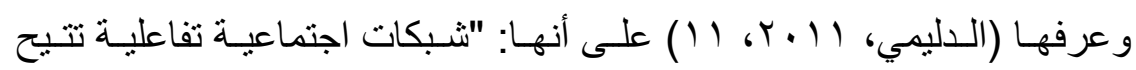
التو اصل لمستخدميها في أي وقت يشاؤون، وفي أي مكان من العالم".

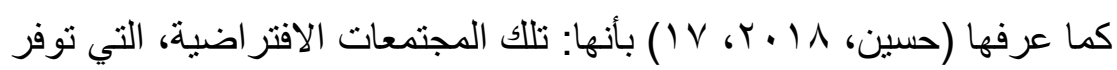
لمستخدميها بنـاء ملف شخصسي تُكنهم من مشـاركة الصور و الملفات وتبادل مقاطع الفيديو، و إنشـاء المدونات الالكترونية، وإجر اء المحادثات الفوريـة، و إرسـال الرسـائل، بطريقة تُلبي احتياجات مستخدميها من ذوي الاهتمامات المتمانلة ليجتمعوا في مجمو عات للتو اصل وتبادل الأفكار ومناقتشتها. مما سبق يتضح أن مو اقع التو اصل الاجتمـاعي عبارة عن تطبيقات تكنولوجية

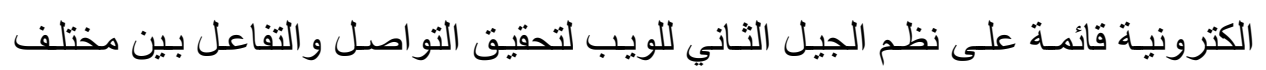


د/ بثينة عبد الله الملا

الأفر اد المنتشـرين حـول العـالم بالمرسـلات المكتوبـة والمسمو عة و المرئيسة مـع تحقيق الاتصال الفوري بما يحقق أكبر فائدة لتجميع الثعوب في مواقع للتو اصل من بعد.

\section{خصائص مواقع التواصل الاجتماعي:}

لمواقع التواصل الاجتماعي العديد من الخصائص التي تميز ها عن باقي المو اقع التع

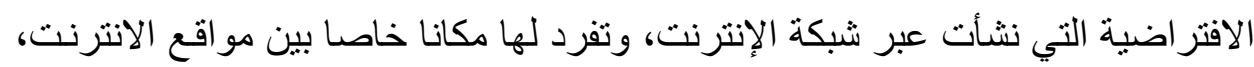

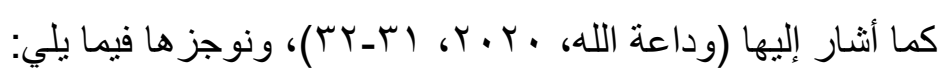

- - التفاعلية: وتعني انتهاء فكرة الاتصال في اتجاه واحد من المرسل إلى المتلقي

$$
\text { و إنما أصبح الاتصال في الاتجاهين. ونفي النهاء }
$$

- التنوع: ويعني تنوع اشكال الاتصـال، وتتوع المحتوى الذي يختاره من خـلال

$$
\text { وسيلة واحدة "الحاسوب". }
$$

- - التكامل: وتتمثل في شبكة الانترنت كمظلـة اتصـالية تجمع بين نظم الاتصـال

$$
\text { و أثنكلها المختلفة. }
$$

- - الفردية والتجزئة: وتتمثل في التمييز بين الحاجـات الفرديـة والقدرات الخاصـة بعملية الاتصال.

- - تجاوز الحدود الثقافية: نتيجة نوفر إمكانيـة الاتصـال ورخص تكلفتها، وسقوط الحواجز الثقافية. - تجـاوز وحدة المكان والزمـان: لا يفترض تواجد أطراف عملية الاتصسال في مكان واحد لتوافر عنصر المرونة والتفاعلية في الاتصال. - - الاستغراق في عمليـة الاتصـال: نتيجـة انخفـاض تكلفـة الاتصـال أو الاستخدام لتو افر البنية الأساسية. 
تتعدد إيجابيات مواقع التواصل الاجتمـاعي في الكثير من المجالات، كمـا أنثـار

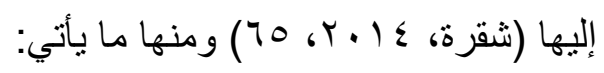

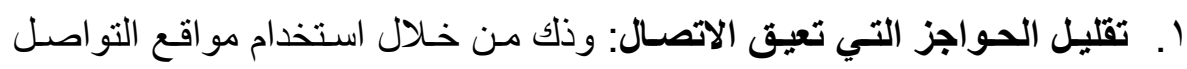

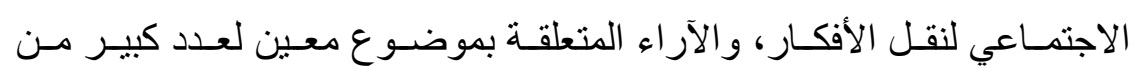

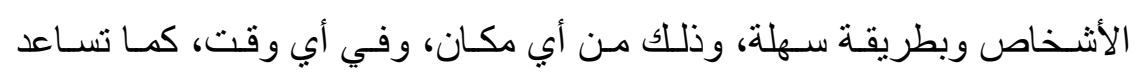

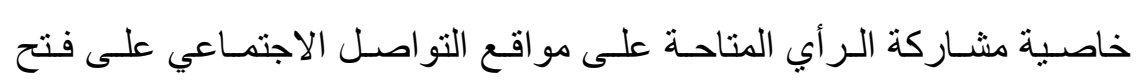
الأبو اب لتبادل الآراء، وتوسيع فرص المشاركة في التعبير عن الر أي.

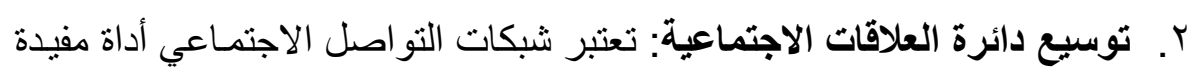

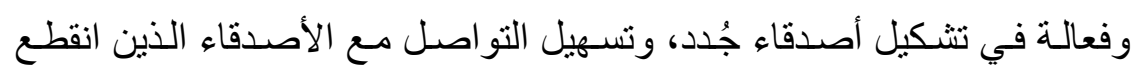

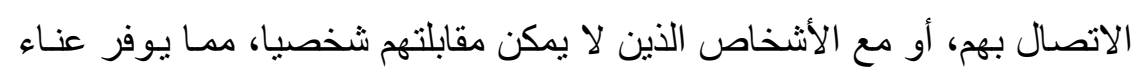
الوصول إليهم.

r. وسيلة فعالـة للترويج: نستخدم الثـركات التجاريـة الثبكات الاجتماعيـة كـأداة

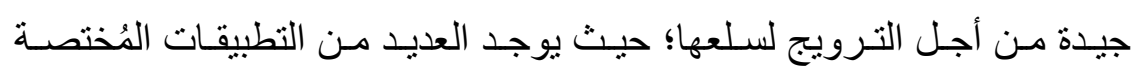
بالترويج لخدمة أو سلعة معينة وبتكلفة أقل، مما يؤدي إلى زيـادة الأربـاح وبأقل التكاليف. سلبيات مواقع التواصل الاجتماعي: يوجد العديد من السلبيات التي تتعلق بمواقع التو اصل الاجتمـاعي، كمـا أثــار

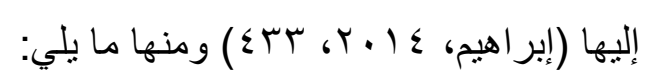
1. مخاطر الاحتيال أو سرقة الهوية: يمكن الوصول إلى المعلومـات الخاصـة التي

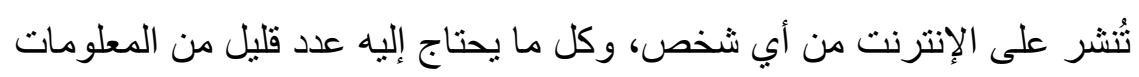

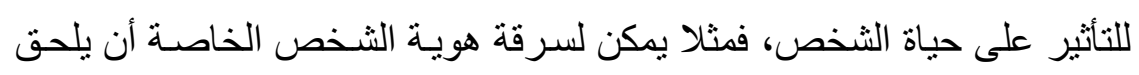


د/ بثينة عبد الله الملا

ضرراً كبيراً به، كما يتضمن هذا الخطر اختراق المعلومات النخصية والتطفل

عليها.

r. إضاعة الوقت: تُعد مواقع التواصل الاجتماعي، وخاصة الفيس بوك و غيره من المواقع التي انتشرت بشكل واسع، وهي أكثر ما ينت استخدامه على الإنترنت،

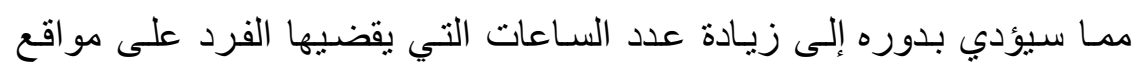
التو اصل الاجتماعي، وقد يتعارض ذللك مع مسؤولياته في العمل، و غير ها. r. غزو شبكات التواصل الافتراضية للخصوصية: ثُكن شبكات التواصل الاجتماعية الثركات الكبرى التي تستهدف الأشخاص بالإعلانـات من البحث

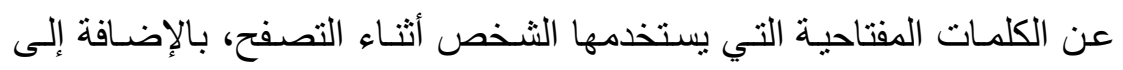
بيانات أخرى، من أجل تزويده بالإعلانات التي تستهدف حاجاته.

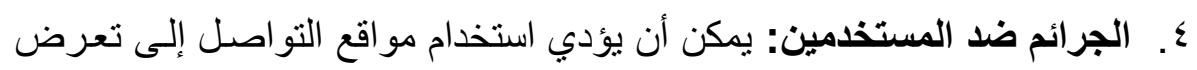

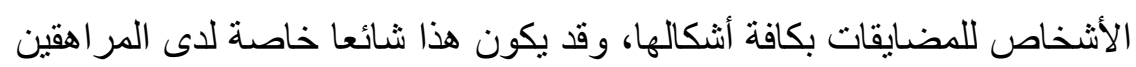
و الأطفال الأصغر سنا بشكل خاص. وبمكن التغلب على هذه السلبيات من خلال غلق المنتديات التعليمية على طلاب

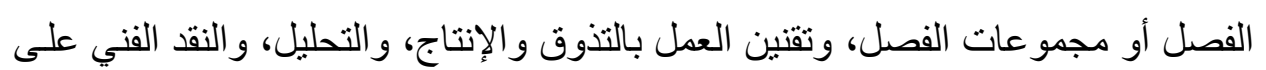

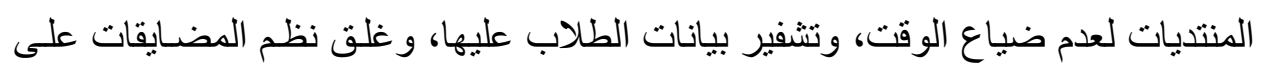
منتدياتها ومنها غلق الإعلانات، و الرسائل المزعجة.

\section{مواقع التواصل الاجتماعي:}

أصبحت مواقع التواصل الاجتمـاعي من الوسـائل الأساسية لتبادل المعلومـات ومتابعة تطور ات الأحداث، وتصدرت مواقع التواصل الاجتماعي ثلاثة مو اقع مهمة هي: وتويتر، ووواتس أب، انستجر ام.

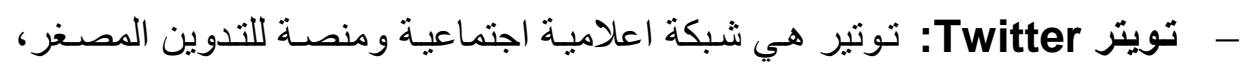

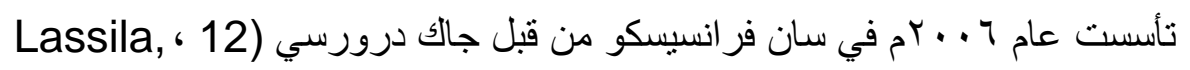


دور مواقع التواصل الاجتماعي في تحقيق أهداف التربية الفنية والاتجاهات نحوها لاى طلاب المرحلة الثانوية

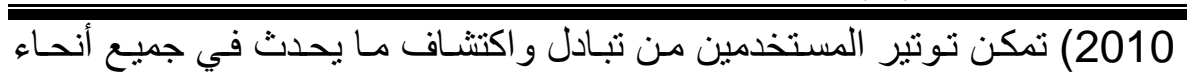

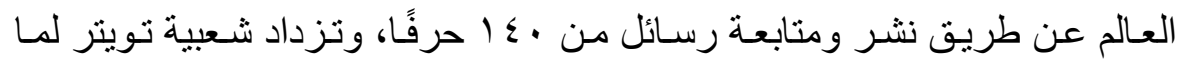
تمتـاز بـه من البسـاطة وخاصـة بسبب فائدتها في الثبكات المتنقلة، وتعتبر فكرة اعطاء المستخدم لعدد محدود من الحروف لكي يثـارك بفكرتـه أو المعلومـة التي لئي

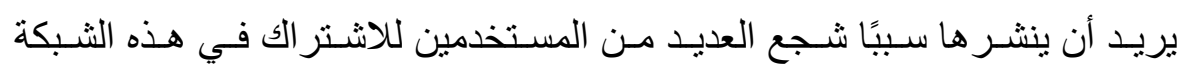

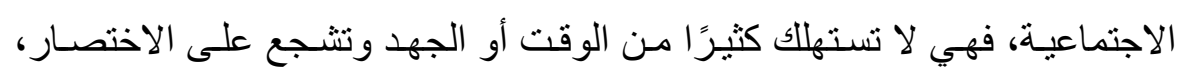
فُيُقبل المدونون والقارئون عليها بشكل كبير (Schneider, 2015, 345).

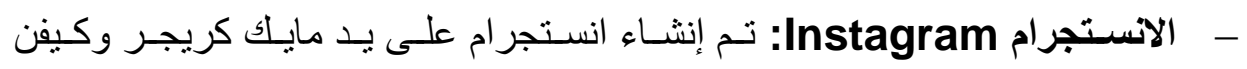

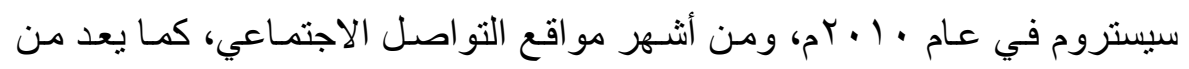

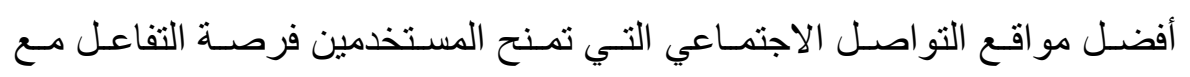

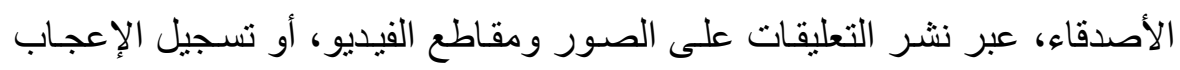
بها. كما ويسمح بالإشـارة إلى الأصدقاء في الصور التي تنتم مشـاركتها، مـا يزيد عملية التفاعل، كما يمكن من رفع عدد لا نهائي من الصور و الفيديو هات و التعديل عليها (Liou, Chih, Hsu \& Huang, 2016, 189). - - الواتس أب WhatsApp: هو تطبيق للتراسل الفوري عبر الهواتف الذكية

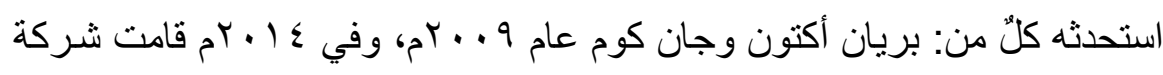

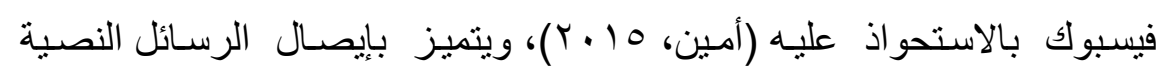

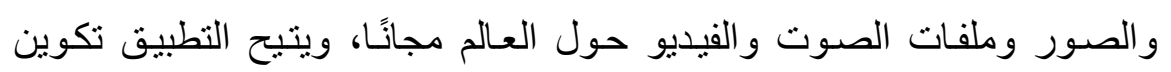

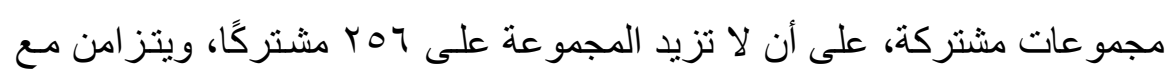
جهات الاتصال المخزنة في الهاتف، وينمو استخدامه سريعًا، وتم اتاحة فتحسه عن لن طريق الكمبيونر بخاصية واتس اب ويب، وادخـال خاصية المكالمـات المرئيسة عام

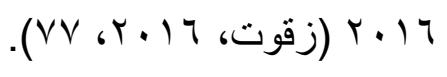

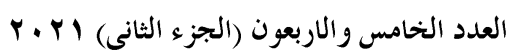

(490)

مجلة كلية التربية- جامعة عين شمس 
المحور الثاني: أهداف التربية القنية

لأهداف التربيـة الفنيـة دورًا كبيرًا؛ حيث أنها بمثابـة التغييرات التي نتوقـع أن يحدثها المنهج في شخصية المتعلم فهو وصف للتغير المنوقع حدوثه في سلوك المتعلم نتيجـة لتزويـده بـالخبرات التعليميـة، وتفاعلـه مـع المواقف التعليميـة الجديدة، وفي هذا

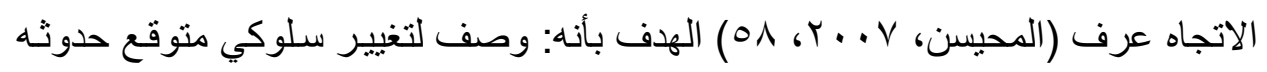
في شخصية المتعلم بعد مروره بخبرة تعليمية ما، وهنا يربط الهدف بعملية التعلم، ويحدد ملعد مقدار التعلم بمقدار التغير، ولتحقيق الهرف، لابد أن يمر المتعلم بخبرة تعلمية يقوم بها.

لذا فأهداف التربية الفنية تمثل النتائج التعليمية لطلابها وتبدأ بدعم الهويـة الدينية و الانتمـاء الـوطني لطلابـه، ورفع مسـتوى التـذوف الفنـي للديهم، وتعـريفهم تـاريخ الفن

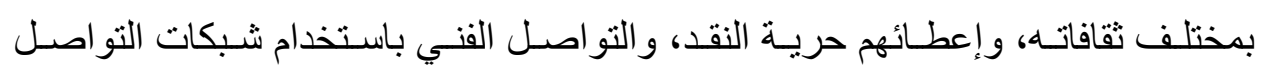
الالكترونية.

\section{أهمية الأهداف في العملية التعليمية:}

تعد الأهداف هي نقطة البدايـة في التخطيط للعمل التربوي، سواء على المدى القريب أو البعيد، وتؤدي إلى تحقيق تعلم أفضل، لأن جهود المعلم والمتعلم ستتركز حول

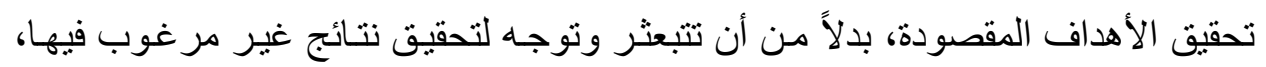
وفي هذا الاتجـاه يمكن استخلاص أهميـة الأهداف التربويـة التعليميـة، كمـا أثـار إليهـا

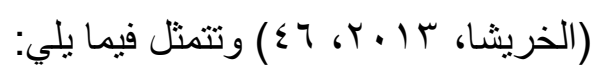

!. تساعد على وضوح الغاية، وتوجيه الجهود، وتتسيقها نحو الهدف المنشود. r. تسـاعد على اختيـار المحتوى، والطريقـة، و الوسـيلة، وأسـلوب تقويم العمليـة التعليمية بأسر ها كما أن السعي لتحقيق الأهداف يتطلب الإيمان؛ حيث يعد ذلك ولك بمثابة حافز للعاملين في الحقل التربوي على البذل و التضحية في سبيل تحقيق

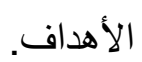


دور مواقع التواصل الاجتماعي في تحقيق أهداف التربية الفنية والاتجاهات نحوها لاى طلاب المرحلة الثانوية ب. تستخدم كدليل للمعلم في عملية التدريس. ع. تساعد على وضع أسئلة للاختبار ات المناسبة. ๑. تشير إلى نوع النشاطات المطلوبة لتحقيق التعلم الناجح.

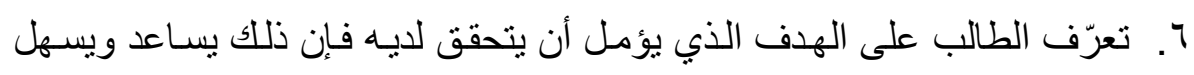
عملية التعلم.

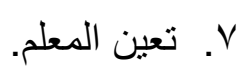

معاييز الأهداف التربوية:

يعد تصنيف الأهداف التربوية، أمراً هامـا حتى نضمن عملية الثمول، وتوجيه

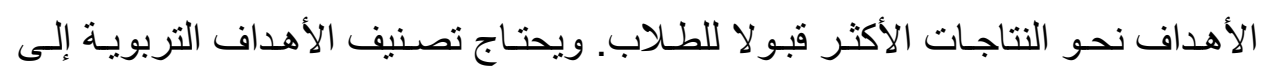
معسايير، وتتنـوع المعـايير بتنـوع التصـنيفات، ومسن معـايير التصـنيفات: احتياجـات المتعلمين، واحتياجات المجتمع، ومحتوى المادة الدراسية، و أنماط السلوك، ومن المعايير

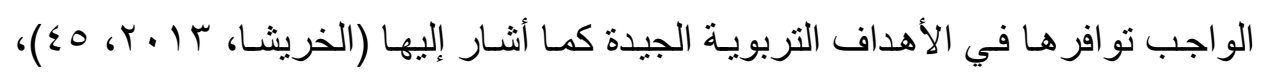

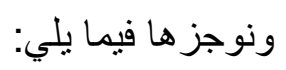

1. أن تستند إلى فلسفة تربويـة اجتماعية سليمة: بمعنى أن تكون فلسفة الأهداف،

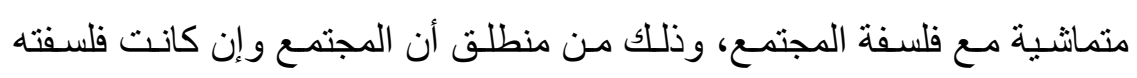
مصـاغة في صـورة عبـار ات عامـة فإنـه يمكن التغلب على العموميـة فيهـا،

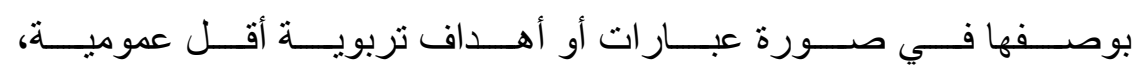
تعكس هذه الفلسفة، وتعمل على ترجمتها في سلوك التلاميذ، وذلك من خلال

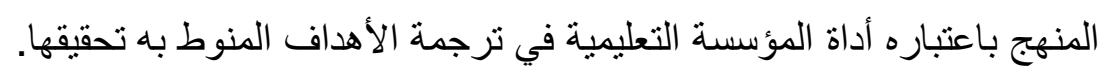

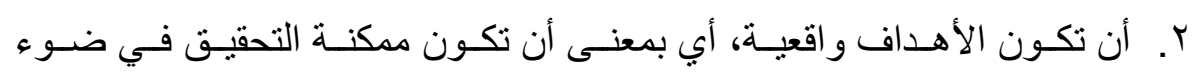
المؤسسات التعليمية العادية. r. أن يراعى في تحديد الأهداف التربوية طبيعة المتعلم، بمعنى أن تحترم الأهداف

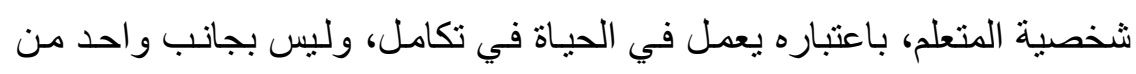


د/ بثينة عبد الله الملا

جو انب الثخصية سو اء أكانت عقلية أو وجدانية أو جسمية (شمولية الأهداف)، وكذلك ينبغي أن تكون الأهداف التربوية، ملائمة لخصائص نمو المتعلم، بحيث بسهل تحقيقها.

ع. . أن تساير الأهداف روح العصر الذي نعيش فيه عصر العلم والتكنولوجيا. ○. أن تكون الأهداف سلوكية بمعنى إمكانية ترجمتها إلى مظاهر سلوكية تتصنع فيها العلاقة بين النشاط التعليمي في المدرسة، والتعبير المرغوب فيه في سلوك التلامبذ.

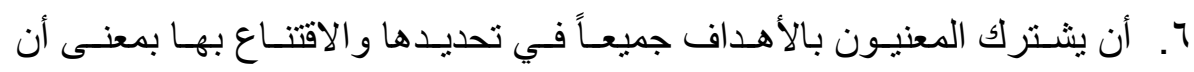
يثارك في وضعها وتحديدها كل المشتغلين بالتدريس وو اضعي المناهج ومؤلفي الكتب.

\section{مصادر اشتقاق الأهداف:}

لا شك أن الأهداف التربويـة لا توضـع بالصدفة، إنمـا تستند إلى مصسادر تشـتق منها و إن هذه المصسادر تختلف بـاختلاف الفلسفة التربويـة التي يتبناهـا المنهج، فـالمنهج الذي يتبنى القلسفة التقدمية يختلف في مصسادر اشتقاق الأهداف عن المنهج الذي يتبنى التواتريـة أو الجوهريـة؛ لأن التقدميين يعتقدون أن المـتعلم ومـا يتصـل بـهـ مسن حاجـات واهتمامات وميول هو المصدر الرئيس لاشتقاق الأهداف التربوية في حين أن الأساسبين يعتقدون أن المواد الدراسية والمعلومات و هضمها تعد المصدر الأساسي الذي نشتق منـه أهداف التربيـة و على الرغم من اختلاف وجهات النظر الفلسفية يمكننا إجمال مصـادر اثتقاق الأهداف التربوية كما أثنار إلبها (عطيه، 0 ( • ب، 9 19) ونوجز ها فيما يلي: ا. ـ الفلسفة التي يتبناهـا المجتمـع وحاجاتـه التي يعبـر عنهـا في عـالم فلسفة الدولـة وحاجاتها لأن الأهداف تحدد في ضوء ما تريده تلك الفلسفة من الفرد و على هذا الأسـاس ينبخـي أن تتجسـ فلسفة المجتمع وقيمتهـه و عاداتـه وتر اثـه في الأهداف 
دور مواقع التو اصل الاجتماعي في تحقيق أهداف التربية القنية والاتجاهات نحوها لاى طلاب المرحلة الثانوية

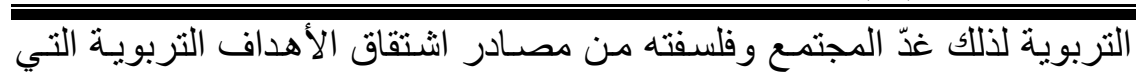

يتبناها المنهج.

r. المتعلم وخصائصه وحاجاته وما يتصل به من ميول واهتمامات لأن المتعلم هو

المستفيد في العملية التربوية فلا بد من أن تتأسس الأهداف على تلك الحاجـات

و الميول و الانطلاق منها في العملية التربوية لتنمية المتعلم تنمية شاملة.

r. التطور العلمي و التكنولوجي في العالم الذي يجب أن يؤخذ بعين الاعتبار في

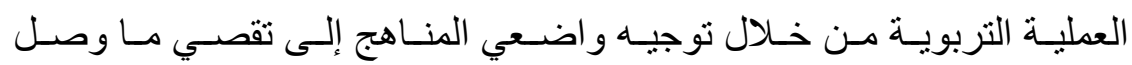

إليه العالم في هذا المجال و الاستناد إليه في اشتقاق الأهداف التربوية.

ع. طبيعة المادة ومعطياته، وذلك بمر اعاة طبيعة المادة وخصائصها؛ حيث لا يمكن

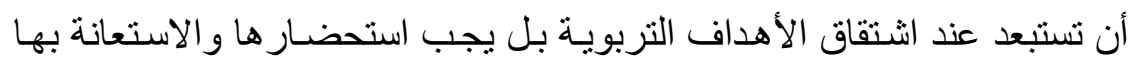

عند صياغتها، لأن لكل مادة معطياتها وخصائصها التي تميز ها من غير ها.

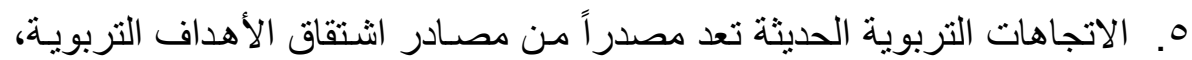
وذللك لأن من المهم ربط أهداف المنهج بالاتجاهات التربوية الحديثة لكي تواكب لهدب التطور ومن هذه الاتجاهات: (تبني مبدأ التعلم الذاتي، وربط ما يتعلمه الفرد في المدرسة بالحياة، و التعلم التعاوني، وتبني مفهوم الجودة في التعلم والتعليم).

\section{أهداف التربية الفنية للمرحلة الثانوية:}

تتعدد أهداف التربية الفنية للمرحلة الثانوية في الكويت في تحقيق الهويـة الدينية

و الانتماء الوطني، وتنمية التذوق الفني، والتعرف على تاريخ الفن، وتتميـة القدرة على

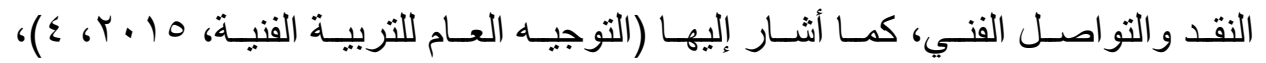

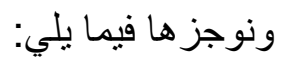

ا. الهويـة الدينيـة والانتمـاء الـوطني، وتتمثنل في إدراك المتعلم أهميـة القيم الأخلاقيـة و الجمالية في العمل الفني، و التعبير من خلال العمل عن قضايا الأمة و الوطن و الدين الإسلامي الحنيف. 
د/ بثينة عبد الله الملا

ب. الإنتاج الفني، وتتمثل في استثمار وقت الطالب و انشـاله بالأعمال الفنية بمـا يعود عليه بالنفع والاستمتاع، واختيار واكتثاف الخامات و المجالات الفنية المناسبة لميوله وحاجاته وقدر اته في التعبير في التعبير الفني. r. التذوق الفني، وتشمل تعرف المتعلم على فلسفة الفن والجمـال و أهميـة ذلك في حيـاة الفرد، و التدرب على مقومـات و عناصـر العمل الفني وربطها بإبداعات وجماليـات الطبيعة وكثف ما بها من أسرار. ع. ـ تاريخ الفن، ويتمثل في التعرف على تاريخ الفنون و الثقافات المختلفة و إثر اء الفكر الفني لدى المتعلم و التعرف على المدارس الفنية. ○. التقد الفني، ويشـمل إعطاء الطالب الحريـة الكاملـة في التحليل و النقد الموضـوعي وإبداء الرأي في الأعمال الفنية بصورة فردية وجماعية، و الفرصة للنقد الذاتي. 7. التواصل الفني، وتشمل الاهتمام بالأنشطة الفنبـة لزيـارة المعـارض و المنتديات الفنيـة بمـا يعـود على الطالب بالمنفعـة الثقافيـة و إثر اء الرؤيـة الفنيـة، واسـتخدام الحاسـوب للاخول في عالم الصفحات التشكيلية للتعرف على مختلف المدارس الفنية.

\section{المحور الثالث: الاتجاه نحو التربية الفنية}

يثــكل الاتجــاه مفهـوم يعكس مجمـوع اسـتجابات الفـرد نحــو الموضــوعات و المو اقف الاجتماعية، التي تختلف نحوهـا استجابات الأفراد بحكم أن هذه الموضـوعات و المواقف تكون جدلية بالضرورة أي تختلف فيها وجهات النظر ، وتتسم استجابات الفرد بالقبول بدرجات متباينة أو الرفض بدرجات متباينة (شحاته و النجار ، س . ؟ ، 7 ( ).

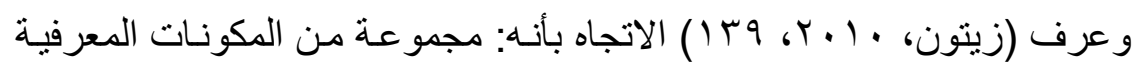
و الانفعاليـة والسـوكية، التي تتصل باستجابة الفرد نحو قضية أو موضـوع أو موقف، وكيفيتها من حيث القبول أو الرفض. 
دور مواقع التواصل الاجتماعي في تحقيق أهداف التربية الفنية والاتجاهات نحوها لاى طلاب المرحلة الثانوية

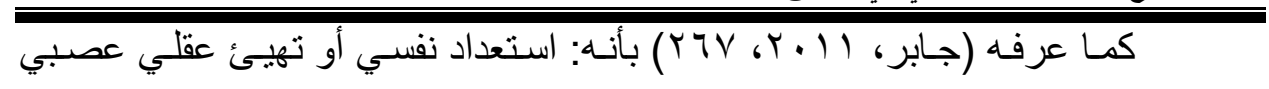

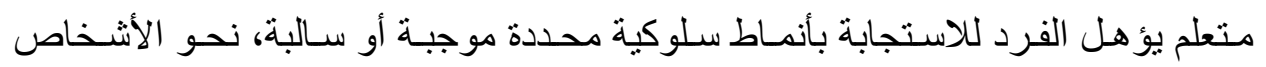
و الجماعات، والأفكار و الحوادث، والأوضاع، الأثياء، أو الرموز لهون.

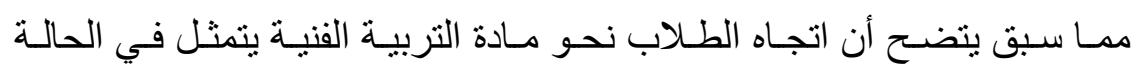

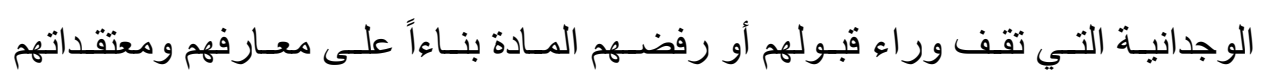
وخبر اتهم السابقة نحوها، لتؤثر في سلوكياتهم واستجاباتهم في المو اقف المختلفة.

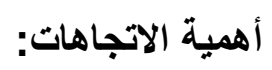

للاتجاهات وظائف عديدة على مستوى السلوك الثخصي و الاجتماعي و التربوي

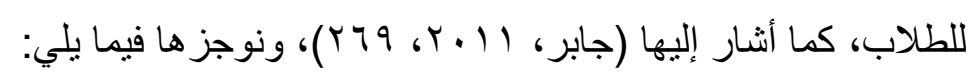
- - - تحدد سلوك الطالب نحو موضوع أو موقف معين.

- - تساعد على اتساق سلوك الطالب وثباته في المواقف المختلفة. - - تسـاعد الطالب على تكوين ميولاً ثابتـة نحو الموضـوعات و المفـاهيم، وبـذلك يتجنب التشتت و المتاهات.

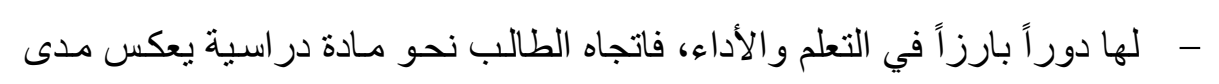
قدر اته على بذل الجهد و التحصيل في هذه ولت المادة.

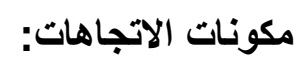

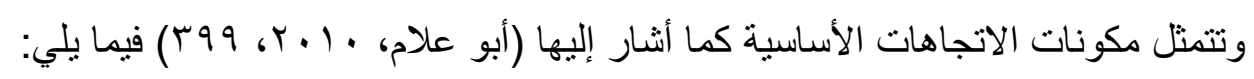

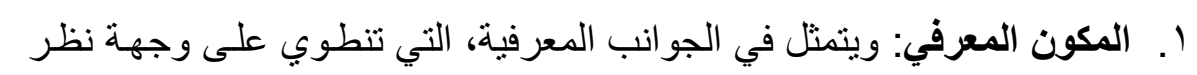
الطالب ذات العلافة بموافقته على موضوع، ويشمل المعلومـات والحقائق

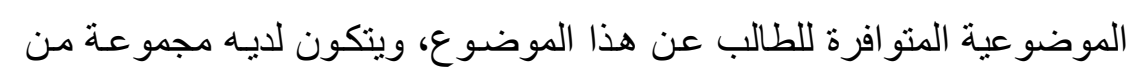
الخبرات التي نشكل الإطار المعرفي لهذه المثيرات. 
Y. المكون الوجداني: ويشير إلى أسلوب شعوري عام يؤثر في استجابة الطالب لقبول موضوع أو رفضه؛ فبعد أن يتكون لايه مجموعة من الخبرات و المعارف عن موضوع معين؛ يظهر بعض الأحاسيس والمشـاعر التي تعكس اتجاهـه الإيجابي أو السلبي نحو الموضوع.

ب. المكون السلوكي: ويتمنثل في مجموعة من التعبيرات والاستجابات الواضحة التي يقدمها الفرد في موقف مـا بعد إدر اكهه ومعرفته، وتكامل جو انب الإدر الك بالإضافة إلى الخبرة والمعرفة التي تساعد على تكوين الانفعال وتوجيهه، يقوم الفرد بتقديم الاستجابة التي تتناسب مع هذا الانفعال. ونجد أن هذه المكونات الثلاثة لا يمكن أن بعدل كل منها بشكل منفصل، فهذه المكونات متر ابطة ويصعب فصل كل مكون عن الآخر.

عوامل تكوين الاتجاه:

هناك عدة عو امل تؤدي دوراً مهاما في تكوين الاتجاه إما سلباً أو إيجاباً، وربمـا تتفاعل تللك العو امل مع بعضها البعض لتكوين الاتجاه، وفيما يلي أبرز هذه العوامل كما

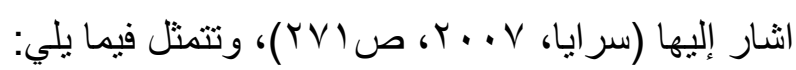
حدة الخبرة وتأثيرها: فالخبرة التي يصساحبها انفعالات حادة ومؤثرة، تكون أكثر فعاليـة في تكوين الاتجاهات؛ لأن الانفعال القوي والمؤثر يعمق الخبرة في نفس الفرد، ويجعله أكثر ارتباطاً بسلوكه في المواقف الاجتماعية المرتبطة بمحتوى الخبرة. تكرار الخبرة: يعتمـد تكـوين الاتجـاه على تكـرار الخبرة، فعندما يجد المتعلم صـوبة متكررة في مادة در اسية معينة، ويعجز عن معالجتها؛ فإنه يكون اتجاها سلبياً نحوها. تكامل الخبرة: عندما ترتبط خبرة الفرد بعنصر من عناصـر البيئة مـع خبراته بالعناصـر الأخرى، تتكامل لديه الخبرة في وحدة كلية تؤدي إلى تعميم هذه الخبرات، وتصبح إطـارا و اقعياً تصدر عنه أحكامه ومو اقفه و استجاباته لمو اقف مشابهة بمو اقف الخبرات السابقة. 
دور مواقع التو اصل الاجتماعي في تحقيق أهداف التربية الفنية والاتجاهات نحوها لاى طلاب المرحلة الثانوية

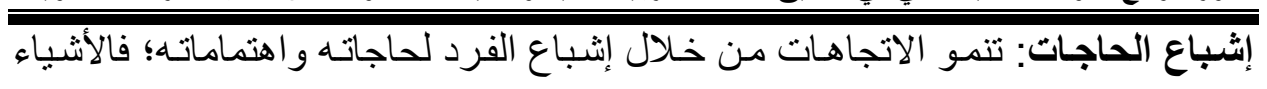

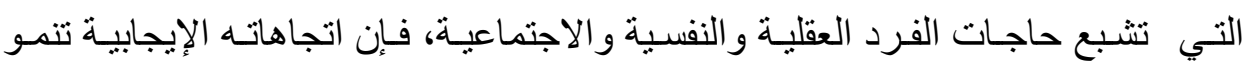
نحو ها، و الأشياء التي لتشبع حاجات الفرد قد يكون اتجاها سلبياً نحو ها.

ويهدف البحث الحالي إلى التعرف على دور مو اقع التواصل الاجتمـاعي (تويتر

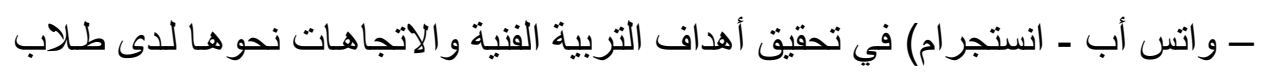
المرحلة الثانوية من وجهة نظر هم في ضوء متغيرات (النوع، الصف، مواقع التواصل الأكثر استخداماً).

الاراسات والبحوث السابقة المرتبطة بمتغيرات البحث: من خلال مر اجعة الدراسات والبحوث السابقة، تبين أنّ الدراسات التي تبحث في دور مواقع التواصل الاجتماعي قليلة جداً، وكانت غالبية الدراسات تتعلق بدور مواقع التواصل الاجتماعي مع الطلاب والتلاميذ في التخصصات المختلفة، أما بالنسبة لدور مواقع التواصل الاجتماعي في تحقيق أهداف التربية الفنية، والاتجاهات نحو ها فقد جاء كل متغير منها مع متغيرات أخرى ولعينات مختلفة عن العينة الحالية وخاصة طلاب الجامعات، وتلاميذ المرحلة الابتدائية، إذ لا يحظى تخصصي ولينات التربية الفنية بكثير من الاهتمام لدى الباحثين، وسنعرض بإيجاز ملخص للار اسات السابقة في مجال

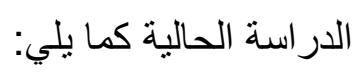

\section{أولاً: دور مواقع التواصل الاجتماعي في التربية القتية.}

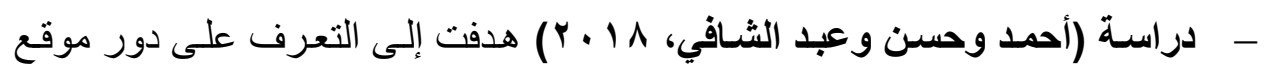

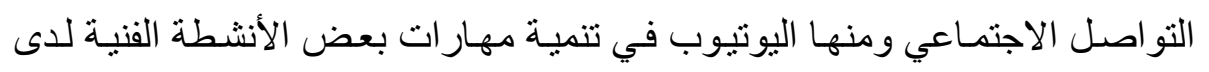

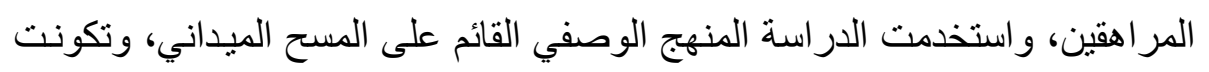
عينة الدر اسة من فئة المر اهقين سن (1) (1) عامًا بالجامعات المصرية بكليات التربية

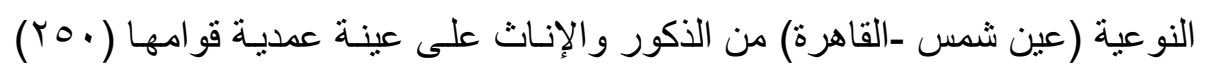


مبحوث، وتمثلت أداة الدراسة في الاستبيان، وتوصلت الدر اسة إلى عدة نتائج أهمها

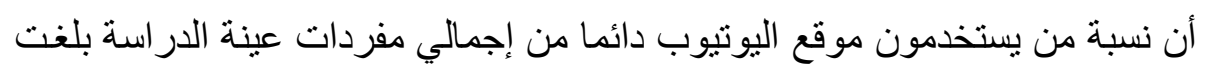

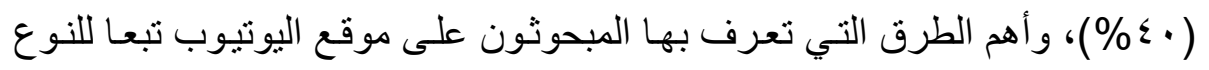

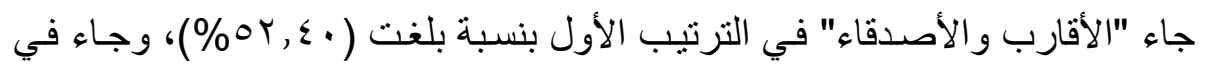
الترتيب الثاني "وسـائل الإعلام"، بنسبة بلغت ( •ـ , •0\%)، وجاء مفهوم الأنشطة

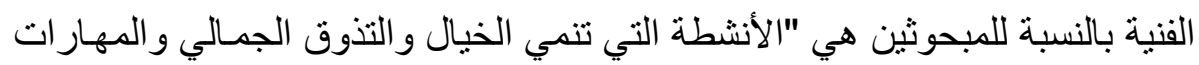

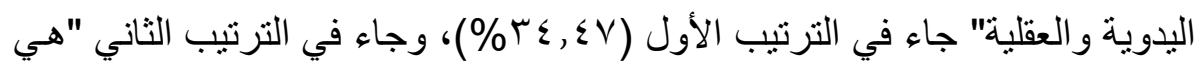

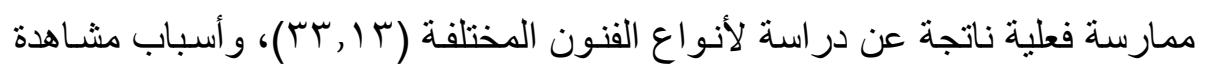

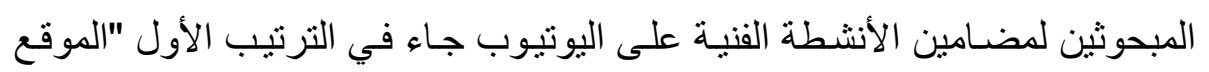
يوفر مقاطع فيديو حول الأنشطة الفنيـة بنسبة (r\%\%)، وجـاء في الترتيب الثناني

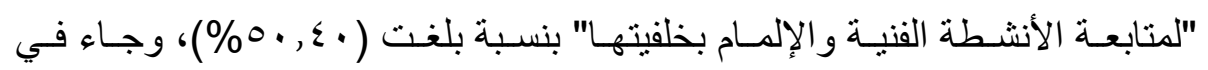
الترتيب الثالث "معرفة آراء ووجهات نظر الآخرين حول الأنشطة الفنية من خـلال

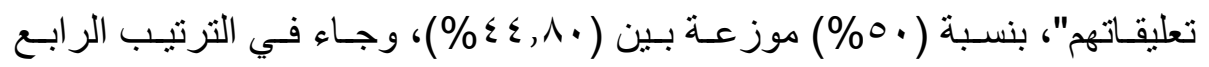

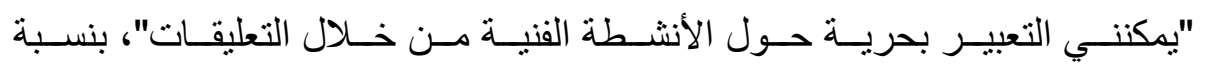
.(\%. $₹ 9,7 \cdot)$

- دراسة (رمزي والعدوي ومحمد، 17 ـ ب) هدفت إلى التعرف على الأدوار المتعددة

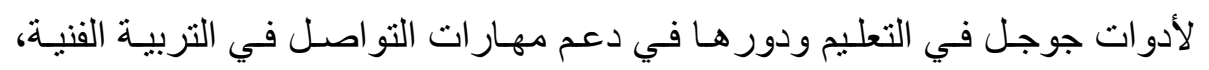
و استخدمت الدراسة المنهج الوصفي التحليلي وذلك بغرض وصف ودف وتحليل الأدوار المتعددة لأدوات جوجل في التعليم ودور هـا في دعم مهار ات التو اصل في التربية الفنية، وتكونت عينـة الدراسـة من أدوات جوجل، وتمثلت أداة الدراسـة في استمارة تحليل الادوات، وتوصلت الدراسـة إلى عدة نتـائج أهمها وجـود العديد مـن أدوات جوجل تستخدم في العملية التعليمية ومنها فصول جوجل الافتر اضية ( Google

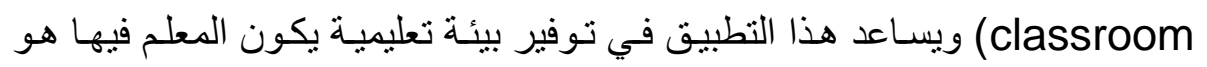


دور مواقع التو اصل الاجتماعي في تحقيق أهداف التربية الفنية والاتجاهات نحوها لاى طلاب المرحلة الثانوية

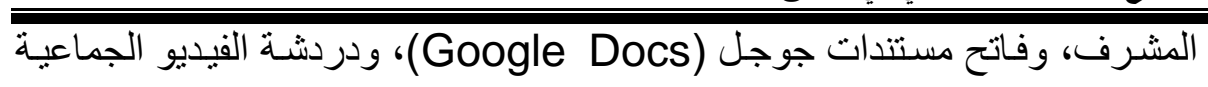

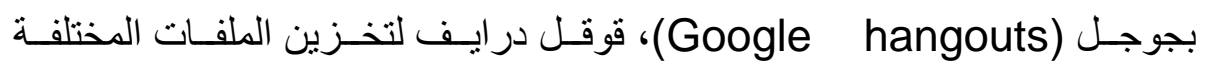
(Google Drive)

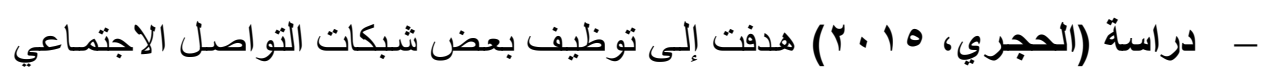
(الانستجر ام ويوتيوب) في عمليات التعليم و التعلم لتدريس مقررات التربيـة الفنيـة، و استخدمت الدراسة المنهج الوصفي التحليلي، لوصف وتحليل الممارسـات التجريبية

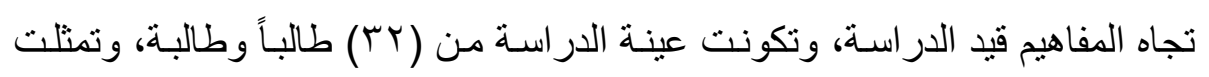

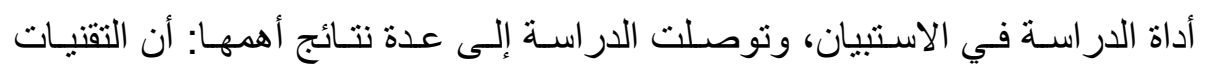
الحديثة في عمليات التعليم و التعلم وبشكل خاص في تدريس الفنون في القرن الحادي و العشرون تسهم في تحديد المعارف والمهار ات و القيم الواجب تضمينها في المنـاهج الدر اسية بشكل عـام وفي منـاهج الفنون و التصميم الجر افيكي بشكل خـاص لتنميـة قدرات الطلبة الذهنية والنفسية و المهارية تجاه التربية الفنية. - دراسة ديويلدي (DeWilde, 2016) هدفت إلى التعرف على اكتثاف كيف يمكن

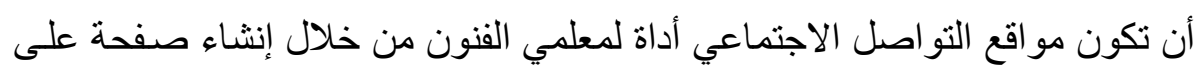

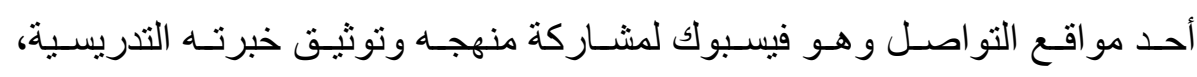

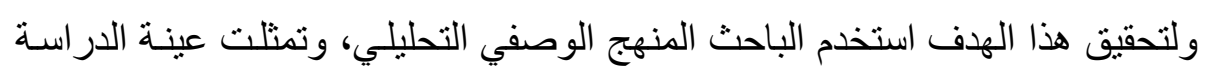

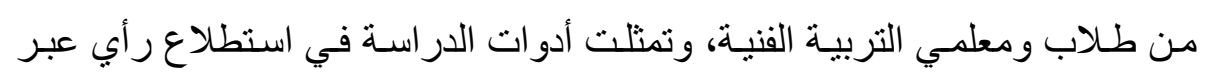

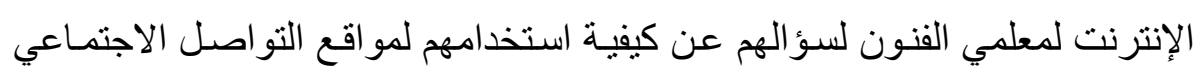

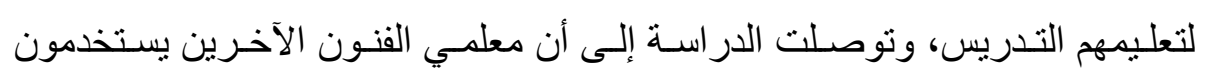

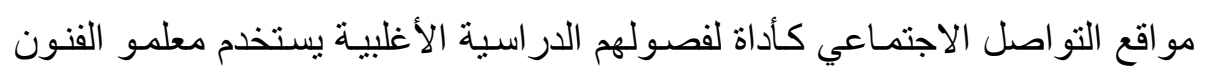
تطبيقات مواقع التواص الاجتماعي للعثور على الأفكار والإلهام، ومع ذلك فإن القليل منهم يستخدمونها كأداة لمشاركة مناهجهم الخاصة. 
د/ بثنية عبد الله الملا

- دراسـة إرسوز وسـاد (Ersöz \& Şad, 2018) هدفت إلى تقييم الأقران على فيس بوك مفيد في تعليم الفنون المرئية، ولتحقيق هذا الهدف استخدم الباحث المنهج الوصـي التحليلي، وتمثلت عينـة الدراسـة في ـالطـلاب- معلمـي الفنـون المرئيـة المحتملين، وتمثلت أدوات الدر اسة في مقابلات جماعية مركزة مـع المشـاركين لجمع البيانات بالإضافة إلى المستندات الرقمية عبر الإنترنت، بمـا في ذلك صور لوحات

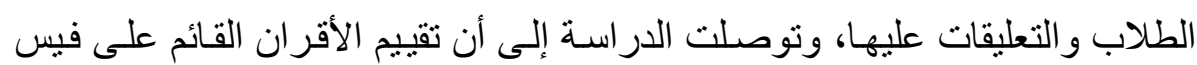
بوك مفيد، لأنه بسـاعدهم على ملاحظة أوجـه القصور لديهم ، و النظر إلى أعمالهم من منظور مختلف وتحسين مهار اتهم الفنيـة بفضل ردود الفعل المثـرة، يتم تعزيز الدافع و الثقة بـالنفس، وقد وجد أيضًا أن تقيم الأقران على فيس بوك يتمتع بميزة

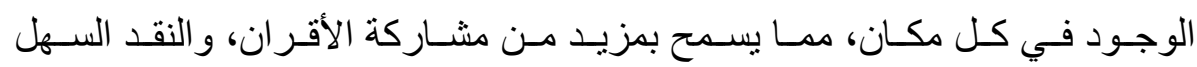
و الموضوعي، وفرص التعلم المستدامة على المدى الطويل، أكد المشـاركون أيضًا على بعض عيوب ممارسة تقييم الأقران على فيس بوك مثل التعليقات الثخصية وضعف جودة المرئيات الرقمية.

ثانيًا: أهداف التربية الفنية.

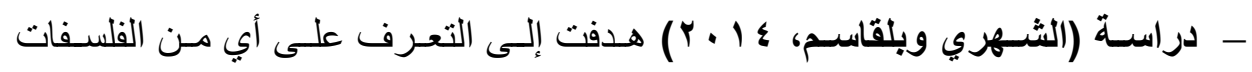
التربويـة تنتمـي الأهداف العامـة لمنهج التربيـة الفنيـة بالمملكـة العربيـة السـعودية، واستخدمت الدر اسة المنهج الوصفي التحليلي وذلك بغرض وصف وتحليل الأهداف العامـة لمـنهج التربيـة الفنيـة وصـلتها بالفلسـفات التربويـة المختلفـة، وتكونـت عينــة الدراسة من محتوى الأهداف العامة لمنهج التربيـة الفنية بالمملكة العربيـة السعودية، وتمثلت أداة الدراسة في استمارة تحليل المحتوى، وتوصلت الدراسـة إلى عدة نتائج

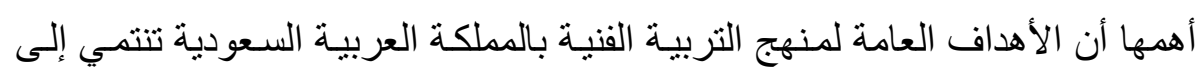

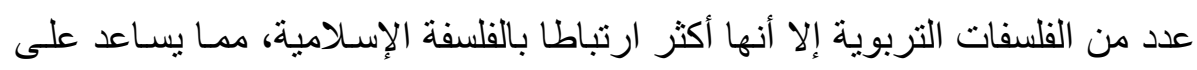
نجاح العملية التعليمية ويؤكد على خصوصية مناهجها. 
دور مواقع التو اصل الاجتماعي في تحقيق أهداف التربية الفنية والاتجاهات نحوها لاى طلاب المرحلة الثانوية

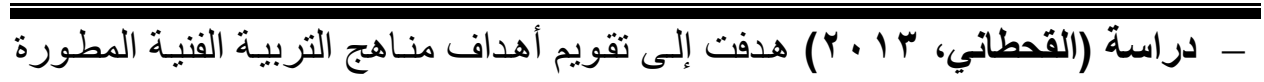

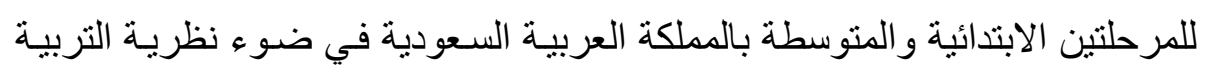

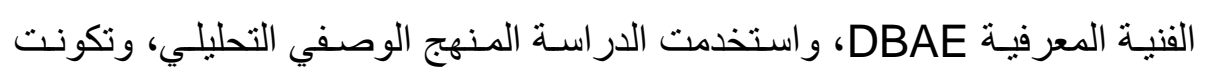
عينة الدراسة من محتوى الأهداف السلوكية لمنهج التربية الفنية للمرحلتين الابتدائية و المتوسطة، وتمثلت أداة الدراسـة في استمارة تحليل محتوى الأهداف، وتوصلت التهن

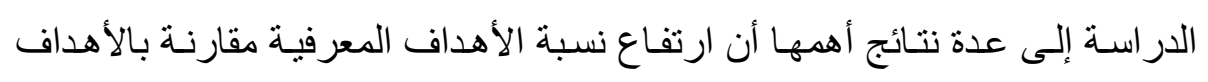

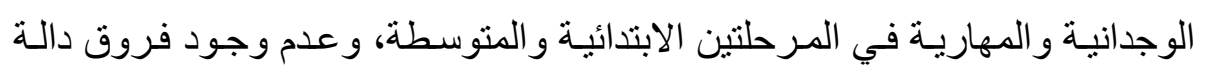
إحصـائياً في متوسـطات توزيـع الأهداف السـلوكية بـاختلاف مسـتوياتها (معرفيـة ومهارية ووجدانية) لكل صف بالمرحلة الابتدائية، و عدم وجود فروق دالة إحصـائياً

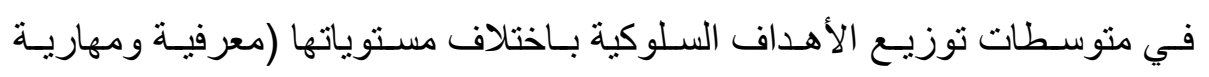
ووجدانية) لكل صف بالمرحلة المتوسطة. - دراسة (محمد، ؛ 99 1 ) هدفت إلى استخدام المدخل التكنولوجي في تحقيق بعض وله

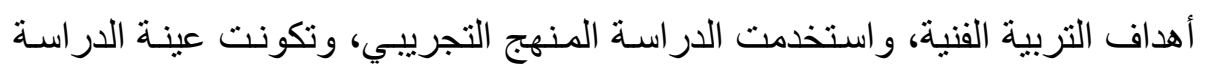
(r) من تلاميذ الصف السـادس الابتدائي، وتمثلت أداة الدراسـة في مقياس التعبير

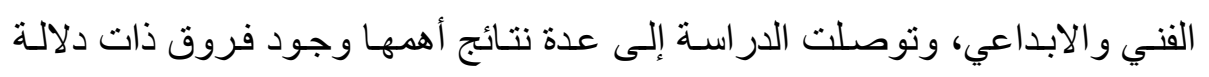

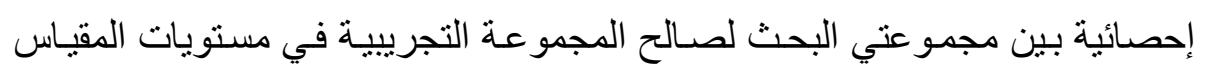
التعبير الفني، والتعبير الإبداعي، وإنتاج له وظيفة نفعية.

\section{ثالثًا: الاتجاه نحو التربية الفتية.}

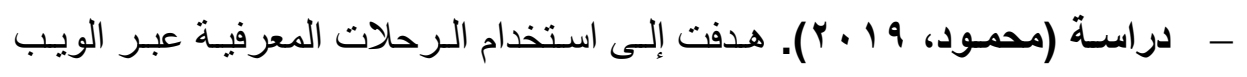
"Web Quests"

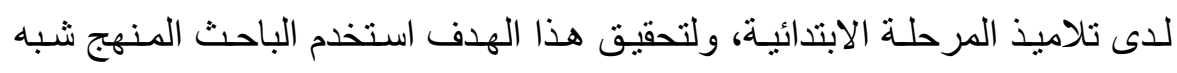

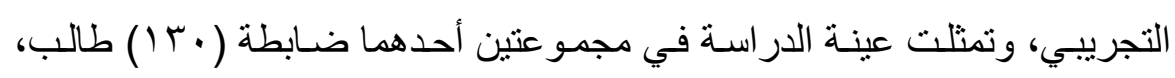

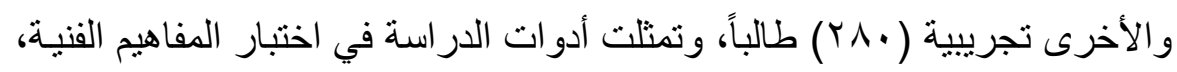


د/ بثينة عبد الله الملا

ومقياس الاتجاه، وتوصلت الدراسـة إلى عدة نتائج أهمها وجود فروق ذات دلالة إحصائية بين مجموعتي البحث في اختبار المفاهيم الفنبـة ومقياس الاتجـاه نحوهـا لصالح المجمو عة التجريبية.

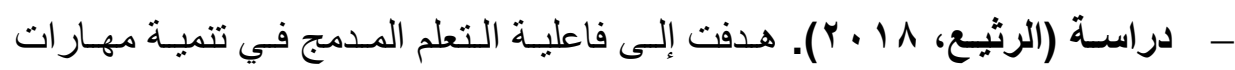

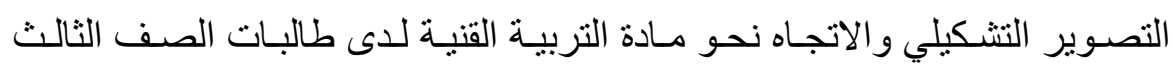
المتوسط، ولتحقيق هذا الهدف استخدم الباحث المنهج شبه التجريبي، وتمثلت عينـة الدراسة (VV) طالبة من طالبات الصف الثالث المتوسط، وتمثلت أدوات الدر اسـة في بطاقة تقويم أداء الطلبة في مهار ات التصوير التشكيلي، ومقياس الاتجـاه نحو مادة التربية الفنية، وتوصلت الدراسة إلى عدة نتائج أهمها وجود فروق ذاء ذات دلالـة إحصائية بين مجمو عتي البحث في بطاقة تقويم أداء الطلبة في مهار ات التصـوير التشكيلي ومقياس الاتجاه نحو التربية الفنية لصالح المجموعة التجريبية.

\section{التعليق العام على الدراسات السابقة:}

يمكن التعليق العام على الدراسات السابقة ببيان أوجه الإفادة والاختلاف، وذللك فيما يلي: - تتنـوع الدر اسـات و البحـوث السـابقة بين التعرف على دور موقع التو اصل الاجتمـاعي ومنها (الانستجر ام ويوتيوب) في تنميـة مهار ات بعض الأنشطة الفنيـة في مقررات

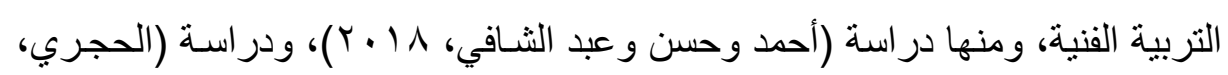

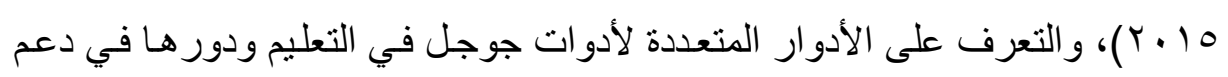
مهار ات التو اصل في التربية الفنية، ومنها در اسة (رمزي و العدوي ومحمد، 7 ( • ؟)،

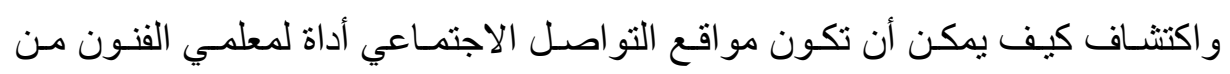
خلال إنثـاء صفحة على فيسبوك لمشـاركة منهجه ونوثيق خبرتـه التدريسية أو تقييم الاقران ومنها دراسة (DeWilde, 2016)، (Ersöz \& Şad, 2018). 
دور مواقع التواصل الاجتماعي في تحقيق أهداف التربية الفنية والاتجاهات نحوها لاى طلاب المرحلة الثانوية

- بعض الدراسات سعت إلى التعرف على أي من الفلسفات التربوية تنتمي الأهداف العامـة

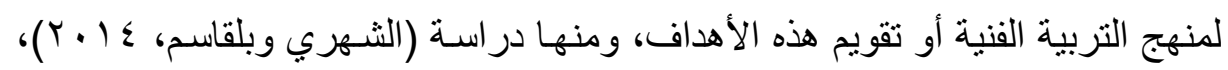

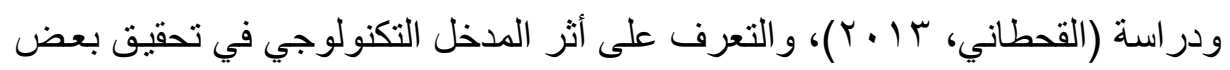
أهداف التربية الفنية على كما في دراسة (محمد، ـ 99 ( ).

- بعض الدراسـات سعت للتعرف على استخدام التقتيـات التكنولوجيـة في تتميـة مهارات

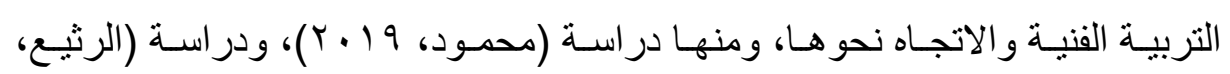

$$
\cdot(r \cdot 11
$$

- يستفيد البحث الحالي من الدراسات والبحوث السابقة فيما يتعلق بالجوانب النظريـة، وبنـاء

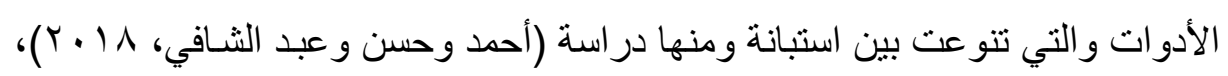

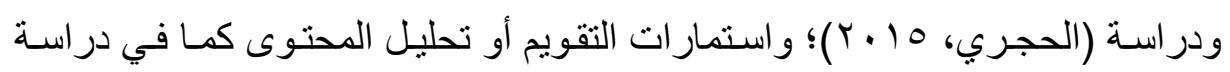

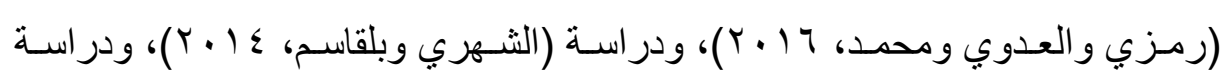

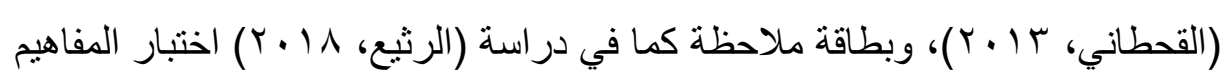

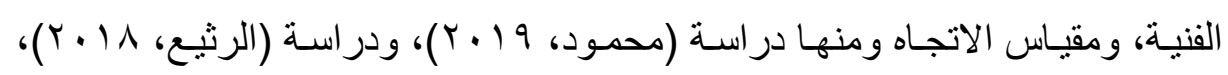

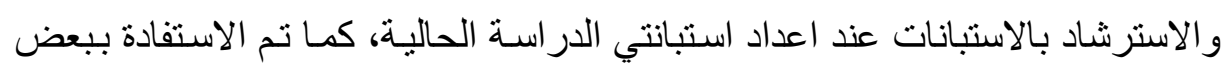
المر اجع التي وردت بها وإجر اءاتها المنهجية، وتفسير النتائج ومناقتنها. - أوصت تلك الدر اسـات والبحوث بالتوسع في استخدام مواقع التو اصل الاجتمـاعي في

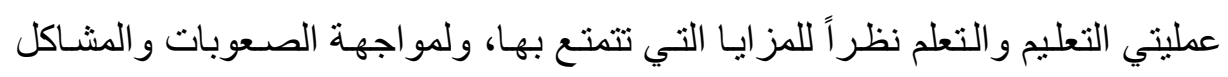
الناجمة عن بعد الأوبئة والفيروسات، وتوصلت إلى قدرة التعلم الإلكتروني على تتميـة

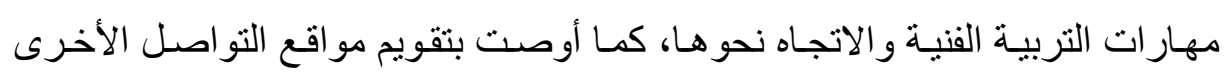

$$
\text { (اليوتيوب وويكي و غسر ها) في عمليتي التعليم والتعلم. }
$$

- ويختلف البحث الحسالي عن الدراسـات، والبحوث السـابقة في التعرف على دور مواقع

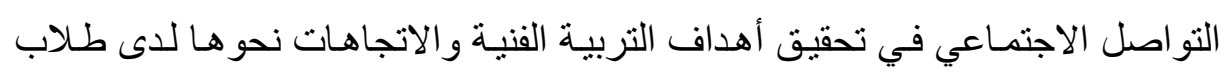


د/ بثينة عبد الله الملا

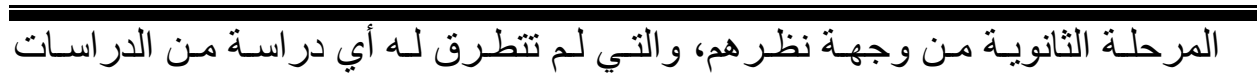
و البحوث السابقة.

$$
\text { إجراءات ونتائج البحث المياني }
$$

اعتمد البحث الحالي في تحقيق أهدافه على أداتين تم توجيههم لطلاب المرحلة الثانوية، و الهدف الرئيسي منهما التعرف على دور مو اقع التواصل الاجتماعي في تحقيق أهداف التربية الفنية، و الكثف عن الاتجاهات نحوها لاى طلاب المرحلة الثانوية، وفيما يلي عرضًا للتحقق من الخصائص السيكومترية للأداتين.

أولاً: استبانة الكثف عن دور مواقع التواصل الاجتمـاعي في تحقيق أهداف التربيـة القنية للمرحلة الثانوية الاهنف من الاستبانة:

حاول البحث الحالي الاستعانة بهذه الاستبانة للإجابة عن الأسئلة الميدانية و التي تتص على:

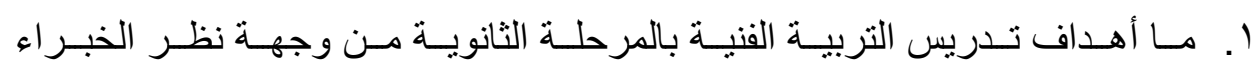

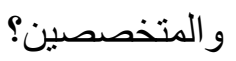

Y. ما دور مواقع التواصل الاجتماعي في تحقيق أهداف تدريس التربية الفنية من وجهة نظر طلاب المرحلة الثانوية. r. مـا مدى اختلاف استجابات عينـة البحث نحو دور مواقع التواصل الاجتمـاعي في

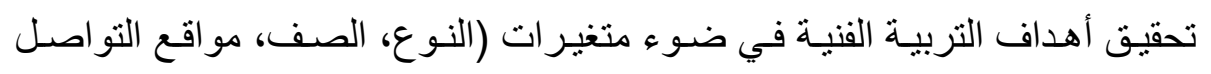

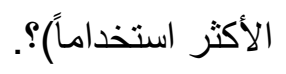
ولإجابة عن الأسئلة السابقة حول دور مواقع التواصل الاجتماعي في تحقيق أهداف التربية الفنية من وجهة نظر طلاب المرحلة الثانوية نم ما يلي: 
نص السؤال الأول على: ما أهداف تدريس التربيـة الفنيـة بالمرحلـة الثانويـة مـن

وجهة من وجهة نظر الخبراء والمتخصصين؟

تم بناء قائمة أهداف التربية الفنية لدى طلاب المرحلة الثانويـة بدولـة الكويت،

وذلك من خلال الرجوع إلى أهداف التربية الفنية للمرحلة الثانوية (التوجيه الفني للتربية

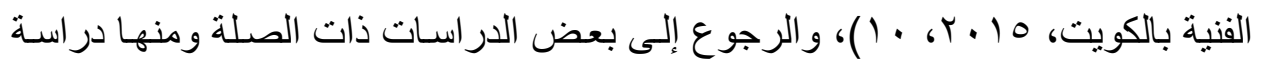

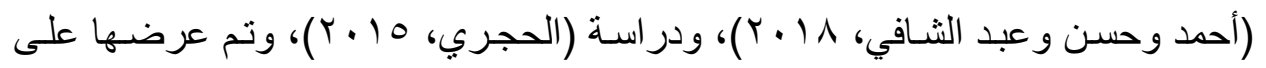

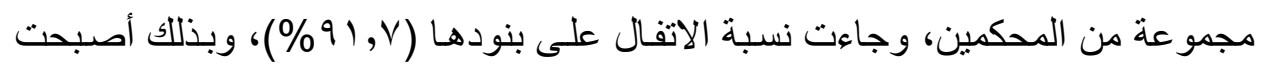
قائمة أهداف تدريس التربية الفنية بالمرحلة الثانوية في صورتها النهائية مكونـة من ست أهداف رئيسة، وتنبثق منها (1 (1) هدفًا فر عيًا؛ وبذلك يكون قد تمت الإجابة عن السؤال الأول الذي نـص على: مـا أهداف تـدريس التربيـة الفنيـة بالمرحلـة الثانويـة مـن وجهـة المرحلة الثانوية من وجهة نظر الخبراء و المتخصصين؟ وتم تحويل إلى استبانة دور مواقع التواصل الاجتماعي في تحقيق أهداف التربية الفنية للمرحلة الثانوية، وبالاستفادة من الاستبانات الموجودة في الدراسات السابقة ومنها الدراسات المذكورة في بناء قائمة الأهداف، وتم التوصل إلى استبانة دور مواقع التواصل الاجتماعي في تحقيق أهداف التربية الفنية للمرحلة الثانوية من وجهة نظرهم، و المكونة من ست أهداف تمثلها (YN) عبارة كما يلي: $\checkmark$ $\checkmark$ $\checkmark$ ل الهـف الرابع: تاريخ الفن. $\checkmark$ ل الهدف السادس: التو اصل الفني. 
مستوى الاستجابة على عبارات الاستبانة:

اشتملت استجابات عينة البحث في ضوء محك مستوى الموافقة على خمسة استجابات بكلًا منهما (موافق بشدة - موافق - محايد - أرفض - أرفض بشدة)؛ ليتضح من خلالها آراء عينة البحث حول دور مواقع التواصل الاجتماعي في تحقيق أهداف التربية الفنية للمرحلة الثانوية.

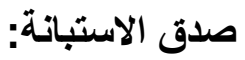
بعد الانتهاء من إعداد الصورة الأولية للاستبانة تم عمل الإجراءات الخاصة

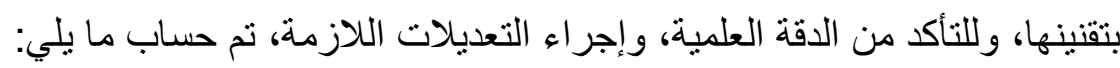
صدق المحتوى أو المضمون:

اعتمد في تحديد صدق الاستبانة على الصدق المنطقي، ويقصد به مدى تمثيل الاستبانة للهفف الذي تقيسه، وقد روعي أثناء إعداد عبار ات الاستبانة أن تكون ممثلة للهدف الذي تقيسه، والذي ينمثل في دور مواقع التواصل الاجتماعي في تحقيق أهداف التربية الفنية للمرحلة الثانوية من وجهة نظر طلاب المرحلة الثانوية، كما اعتمد على الصدق الظاهري في تحديد صدقه، وتم وضع تصور مبدئي له، وبعد إعداد الصورة الأولية تم التحقق من صدقه عن طريق المحكمين، من أساتذة التربية وعلم النفس، وذلك للحكم على مدى ملاءمة الأهداف المختلفة ومدى وضوح عباراتها وارتباطها بالهدف الذي تتنمي إليه، وفى ضوء ما أبداه المحكمون من آراء، أجريت التعديلات اللازمة، كما تم عرض الصورة النهائية للاستبانة على مجموعة من المحكمين المتخصصين، فتم إعادة صياغة بعض العبار ات وحذف البعض الآخر، و أضيفت عبار ات جديدة وذلك حتى مئى تتلاءم الاستبانة مع طبيعة البحث الحالي ويصبح صالحًا للتطبيق.

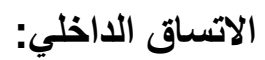

ويقصد به تحديد التجانس الداخلي للاستبانة، بمعنى أن تهدف كل عبارة إلى فياس نفس الوظيفة التي تقيسها العبارات الأخرى، ويستخدم لاستبعاد العبارات غير 
دور مواقع التواصل الاجتماعي في تحقيق أهداف التربية الفنية والاتجاهات نحوها لاى طلاب المرحلة الثانوية

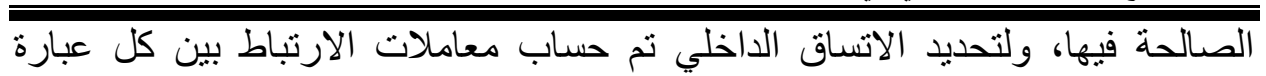

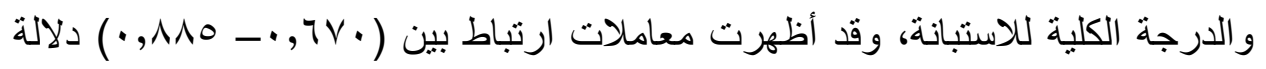
إحصائية عند مستوى ( ( . . •)، وبذلك أصبحت الاستبانة تتمتع بدرجة عالية من الاتساق الاخلي.

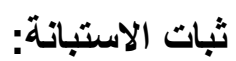

يقصد بثبات الاستبانة دقتها في القياس، والملاحظة و عدم تناقضها مع نفسها، أو أن الاستبانة تعطى نفس النتائج إذا استخدمت أكثر من مرة تحت نفس الظروف، وفئ أو أو ظروف متماثلة، وتم حساب الثبات للتحقق من الآتي: - مدى وضوح تعليمات الاستبانة.

- مدى سلامة الصياغة الخاصة بمفرداتها ووضوحها.

- مدى ملاعمة مفردات الاستبانة للبيئة و الثقافة الخاصة بالمجال وللغرض الذي

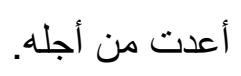

تم حساب ثبات الاستبانة باستخدام معامل ألفا كرومباخ وذللك باستخدام البرنامج الإحصائي (SPSS, v23) عن طريق تطبيق الاستبانة على عينة استطلاعية قوامها

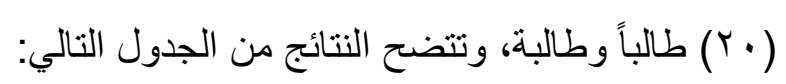

جدول (1)

يوضح معامل ثبات الفا كرونباخ للأهداف الفرعية للاستبانة

\begin{tabular}{|c|c|c|c|}
\hline معامل الفا كرونباخ & عدد العبارات & الأهداف الفرعية للاستبانة & الأهداف \\
\hline$\cdot, \wedge V Y$ & 0 & الهوية والانتماء الوطني & الأول \\
\hline.,$\vee \wedge \uparrow$ & 0 & الإنتاج الفنى. & الثانى \\
\hline $.11 T$ & 0 & التذوق القني. & الثالث \\
\hline$\cdot, \wedge \leqslant \Gamma$ & $r$ & تاريخ الفن. & الرابع \\
\hline$\cdot, \mathrm{V} 9 \mathrm{r}$ & $\varepsilon$ & النقد الفني. & الخامس \\
\hline.$\Lambda \odot V$ & 7 & التواصل الفنى & السنادس \\
\hline • & rA & \multicolumn{2}{|l|}{ اجمالى الاستبانة } \\
\hline
\end{tabular}


د/ بثينة عبد الله الملا

ثاتيـا: مقياس اتجـاه طلاب المرحلة الثانويـة نحو التربية الفنبة في ضوء دور مواقع التواصل الاجثماعي الكهف من المقياس:

حاول البحث من خلال الاستعانة بهذا المقياس أن يجيب عن الأسئلة الميدانية

$$
\text { و التي نصت على: }
$$

ع. . مـا اتجاهـات طـلاب المرحلـة الثانويـة نحـو التربيـة الفنيـة في ضـوء دور مواقع

$$
\text { التو اصل الاجتماعي من وجهة نظر هم؟ }
$$

๑. مـا مدى اختلاف استتجابات عينـة البحث حول اتجاهـاتهم نحو التربية الفنبـة في ضوء دور مو اقع التو اصل الاجتمـاعي تعزي لمتغيرات (النوع، الصف، مواقع

$$
\text { التو اصل الأكثر استخداماً)؟ }
$$

وللإجابة عن تللك الأسئلة حول اتجاهات طلاب المرحلة الثانوية نحو التربية الفنية في ضوء دور مو اقع التواصل الاجتماعي من وجهة نظر هم، تم بناء مقياس الاتجاه نحو التربية الفنية بالرجوع إلى بعض الدر اسات ومنها در اسة محمود (9 19 . ب)، والرثيع

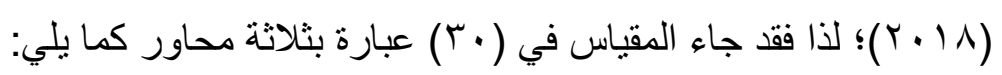
ل أولًا: أهمية التربية الفنية.

ل

$\checkmark$

مستوى الاستجابة على عبارات المقياس:

اشتملت استجابات عينة البحث في ضوء محك مستوى الموافقة على خمسة استجابات بكلًا منهما (موافق بشدة - موافق - محايد - أرفض-أرفض بشدة)؛ ليتضح من خلالها آراء عينة البحث حول اتجاهات طلاب المرحلة الثانوية نحو التربية الفنية في ضوء دور مواقع التواصل الاجتماعي من وجهة نظر هم. 
بعد الانتهاء من إعداد الصورة الأولية للمقياس تم عمل الإجراءات الخاصة بتقنينه، وللتأكد من الدقة العلمية، و إجر اء التعديلات اللازمة، تم حساب ما يلي:

صدق المحتوى أو المضمون:

اعتمد في تحديد صدق المقياس على الصدق المنطقي، ويشير إلى مدى تمثيل المقياس للهدف الذي يقيسه، وروعي في العبارات أن تكون ممثلة للهدف الذي تقيسه، كما اعتمد على الصدق الظاهري بوضع تصور مبلئي للمقياس، وعرضه على مجموعة من المحكمين، من أساتذة التربية وعلم النفس، وذللك للحكم على مدى ملاءمة محاوره ومدى وضوح عبار اته وارتباطها بالمحور الذي تنتمي إليه، وفى ضوء ذلاء ذلك، أجريت التعديلات اللازمة، كما تم عرض الصورة النهائية للاستبانة على مجموعة من المحكمين

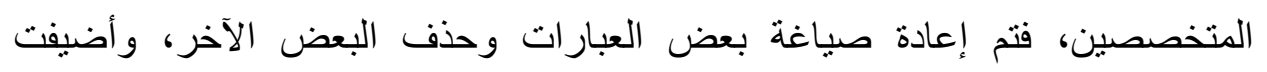
عبارات جديدة وذلك حتى يتلاءم المقياس مع طبيعة البحث الحالي ويصبح صالحًا للتطبيق.

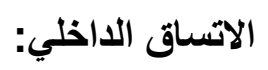
ويشير إلى تحديد التجانس الداخلي للمقياس، ولتحديد الاتساق الداخلي تم حساب معاملات الارتباط بين كل عبارة و الدرجة الكلية للمقياس، وقد أظهرت معاملات ارتباط ولتئل

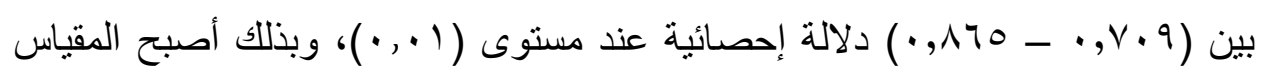
بتمتع بدرجة عالية من الاتساق الداخلي. ثبات المقياس: يقصد بثبات المقياس دقته في عملية القياس، والملاحظة وعدم تناقضها مع

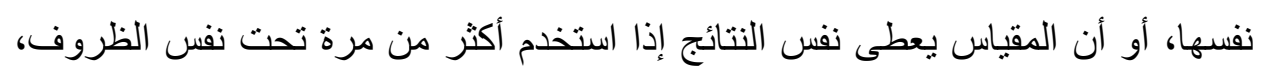

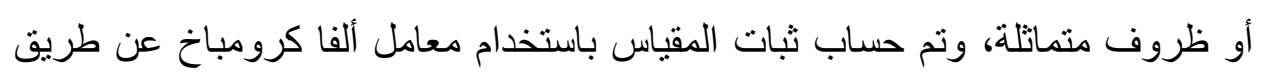


د/ بثينة عبد الله الملا

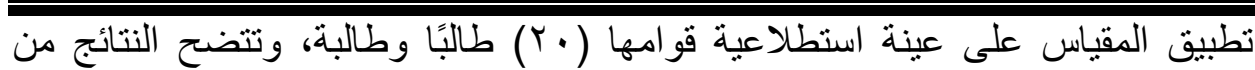

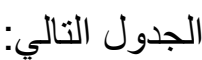

جدول (r)

يوضح معامل ثبات الفا كرونباخ للمحاور الفرعية للمقياس

\begin{tabular}{|c|c|c|c|}
\hline معامل القا كرونباخ & العبارات & المحار الفرعية للمقياس & المحاور \\
\hline$\cdot, \vee \wedge 0$ & 1. & أهمية التربية الفنية. & أولًا \\
\hline$\cdot, 1890$ & 1. & تذوق مادة التربية الفنية. & ثَانيًا \\
\hline - vor & 1 . & وارتباط مادة التربية الفنية بحياة الطلاب & ثُالثًا \\
\hline$\cdot, \mathrm{V} \vee \leqslant$ & $r$. & إجمالي المقياس & \\
\hline
\end{tabular}

تم تفريغ بيانات الاستبانة باستخدام الجداول التكرارية لكل مفردة والتي شملت الاستجابات (موافق بشدة - موافق - محايد - أرفض - أرفض بشدة) في ضوء محك مستوى الموافقة، ثم حساب التكرارات والنسبة المئوية، والوزن النسبي والانحر افات المعيارية، وقد تم استخدام البرنامج الإحصائي (SPSS) في إجر اء تللك العمليات.

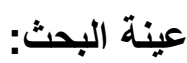

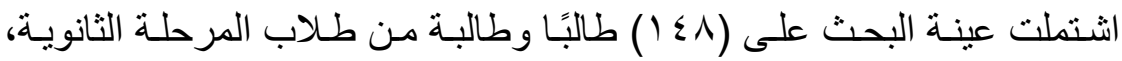
منهم (ro) طالبًا، (97) طالبة، ويوضح الجدول التالي الاعداد طبقا لمتغير اتهم المختلفة، ويوضح الجدول التالي توزيع أفراد العينة حسب متغير المعدل الدراسي:

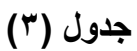

يوضح توزيع أفراد العينة تبعا لمتغيرات البحث

\begin{tabular}{|c|c|c|c|c|}
\hline النسبة & العدد & التصنيف & المتغير & العينة \\
\hline$\%$ ro, & Or & ذكور & \multirow{3}{*}{ النوع } & \multirow{4}{*}{$1 \leqslant 1$} \\
\hline$\% \curlyvee \leqslant, 9$ & 99 & إناث & & \\
\hline$\% 1 \ldots$ & $1 \leqslant \Lambda$ & الإجمالي & & \\
\hline$\% 4 \cdot, 1$ & 19 & العاشر & الصف الدراسي & \\
\hline
\end{tabular}

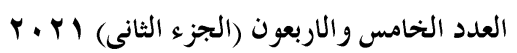

(511)

مجلة كلية التربية- جامعة عين شمس 
دور مواقع التواصل الاجتماعي في تحقيق أهداف التربية الفنية والاتجاهات نحوها لاى طلاب المرحلة الثاتوية

\begin{tabular}{|c|c|c|c|c|}
\hline النسبة & العدد & التصنيف & المتغير & العينة \\
\hline$\% \backslash 0,7$ & $r r$ & الحادي عشر & & \\
\hline$\% Y \leqslant, r$ & rq & الثاني عشر & & \\
\hline$\% 1 \ldots$ & $1 \leqslant 1$ & الإجمالي & & \\
\hline$\%$ Yo, V & $\mu \wedge$ & تويثر & \multirow{4}{*}{ مواقع التواصل الأكثر } & \\
\hline$\%$ Yo & $r v$ & واتس أب & & \\
\hline$\% \leqslant q, r$ & $V r$ & انستجرام & & \\
\hline$\% 1 \ldots$ & $1 \leqslant 1$ & الإجمالي & & \\
\hline
\end{tabular}

أولًا: نتائج الاستبانة

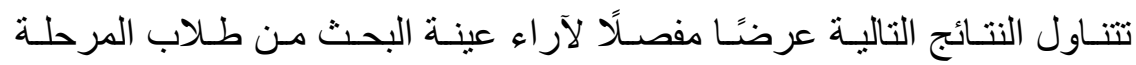

الثانويـة بدولـة الكويـت حول محساور الاستبانة الستة، وذلك للإجابـة على سؤال البحـث الثاني، ليتم الكثف عن مستوى الموافقة على دور مو اقع التواصل الاجتمـاعي في تحقيق أهداف التربية الفنية من وجهة نظر طلاب المرحلة الثانويـة، وفيمـا يلي النتائج بصـورة

مفصلة.

نتائج السؤال الثاني:

ينص السؤال الثاني على: ما دور مواقع التواصل الاجتماعي في تحقيق أهداف

التربية الفنية من وجهة نظر طلاب المرحلة الثانوية؟ الهوف الأول: الهوية والانتماء الوطني

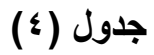

التكرارات والنسب والوزن النسبي والانحراف المعياري ومستوى الموافوافقة المرتبطة بدور

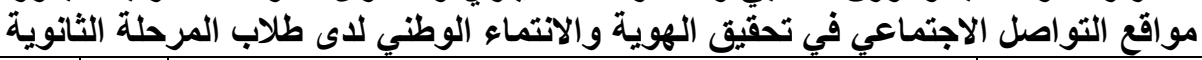

\begin{tabular}{|c|c|c|c|c|c|c|c|c|c|c|c|c|c|c|}
\hline \multirow{3}{*}{$\begin{array}{l}3 \\
y \\
\overline{3} \\
\text { 离 }\end{array}$} & \multirow{3}{*}{$\begin{array}{l}\frac{\overline{3}}{3} \\
\frac{9}{3} \\
\frac{3}{3}\end{array}$} & \multirow{3}{*}{$\begin{array}{l}\overline{3} \\
3 \\
\overline{3} \\
\text { 子. }\end{array}$} & \multicolumn{10}{|c|}{ مستوى الموافقة } & \multirow{3}{*}{ العبازة } & \multirow{3}{*}{ م م } \\
\hline & & & \multicolumn{2}{|c|}{ أرفض بشدة } & \multicolumn{2}{|c|}{ أرفض } & \multicolumn{2}{|c|}{ 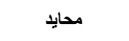 } & \multicolumn{2}{|c|}{ موافق } & \multicolumn{2}{|c|}{ موافق بثدة } & & \\
\hline & & & $\%$ & ك & $\%$ & ك & $\%$ & ك & $\%$ & ك & $\%$ & ك & & \\
\hline & & & & & & & & & & & & & ني مواقع التواصل الاجتماعي على: & \\
\hline موافق & $\cdot, 1$ & $\varepsilon, 11$ & - & - & - & - & $1 \wedge, r$ & rV & $O r, V$ & $\vee \wedge$ & $r q, 1$ & $\varepsilon r$ & إلفني. أهميةُ القيم الأخلاقِية فَي العمل & 1 \\
\hline موافق & $\cdot, \vee \vee$ & r,97 & - & - & $1, \varepsilon$ & r & $r q, 1$ & $\leqslant r$ & $\approx 1,9$ & ir & $r v, v$ & $\varepsilon 1$ & 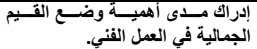 & $r$ \\
\hline موافق & $\cdot 90$ & $r, 91$ & $\cdot, r$ & $r$ & $\varepsilon, 1$ & 7 & $r \bullet, v$ & $r \Lambda$ & $r v, r$ & 00 & $r 1,1$ & $\leqslant 7$ & 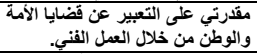 & $r$ \\
\hline موافق & $1, r r$ & $r, 71$ & $\mathrm{v}, \varepsilon$ & 11 & $\wedge, \wedge$ & it & $r q, v$ & $\varepsilon \varepsilon$ & $r r, T$ & ro & $r \cdot, \varepsilon$ & $\leqslant 0$ & 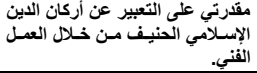 & $\varepsilon$ \\
\hline
\end{tabular}

العدد الخامس واللربعون (الجزء الثانى) ا Y ب r

(512)

مجلة كلية التربية- جامعة عين شمس 
د/ بثينة عبد الله الملا

\begin{tabular}{|c|c|c|c|c|c|c|c|c|c|c|c|c|c|c|}
\hline \multirow{3}{*}{$\begin{array}{l}\text { 至 } \\
\text { 产 } \\
\text { 晋 }\end{array}$} & \multirow{3}{*}{ 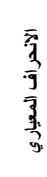 } & \multirow{3}{*}{$\begin{array}{l}\overline{3} \\
3 \\
7 \\
3\end{array}$} & \multicolumn{10}{|c|}{ مستوى الموافقة } & \multirow{3}{*}{ العبارة } & \\
\hline & & & \multicolumn{2}{|c|}{ أرفض بشدة } & \multicolumn{2}{|c|}{ أرفض } & \multicolumn{2}{|c|}{ محايد } & \multicolumn{2}{|c|}{ موافق } & \multicolumn{2}{|c|}{ موافق بثدة } & & \\
\hline & & & $\%$ & s & $\%$ & ت & $\%$ & s & $\%$ & s & $\%$ & s & & \\
\hline 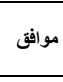 & $1, r r$ & $r, v$. & $\mathrm{v}, \mathrm{\varepsilon}$ & 11 & $\Lambda, \wedge$ & ir & $r, r$ & $r \pi$ & $r a, 1$ & $\varepsilon r$ & rr, \& & «^ & 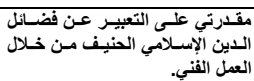 & 。 \\
\hline موافق ل مو لم & זיו, & $r, \Lambda 4$ & \multicolumn{2}{|c|}{ ro } & \multicolumn{2}{|c|}{$r \varepsilon$} & \multicolumn{2}{|c|}{ ino } & \multicolumn{2}{|c|}{ rVT } & \multicolumn{2}{|c|}{ Tre } & إجمالي الهاف الأول & \\
\hline
\end{tabular}

بالنظر إلى البيانات الإحصائية المفصلة لآراء عينـة البحث من طلاب المرحلـة الثانوية حول دور مو اقع التواصل الاجتمـاعي في تحقيق الهويـة والانتمـاء الوطني للى

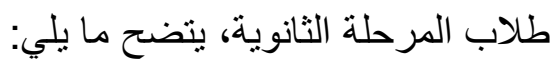
- - جـاء الهدف الأول الهويـة و الانتمـاء الـوطني للدى طـلاب المرحلـة الثانويـة في الكويت عند مسنوى (مو افق) بوزن نسبي (T,人؟) بما يعد مؤشرًا مرتفعًا لدور

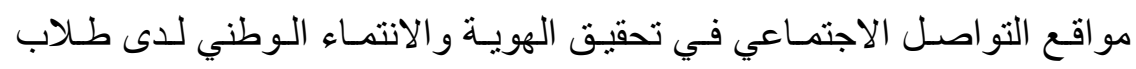
المرحلة الثانوية.

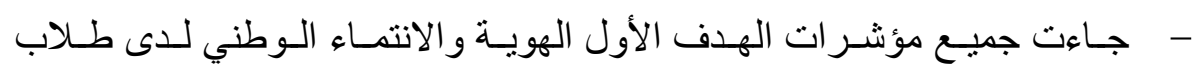

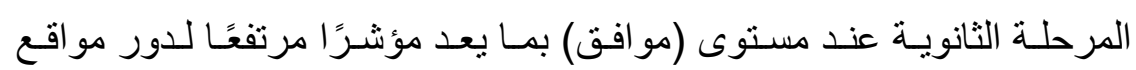

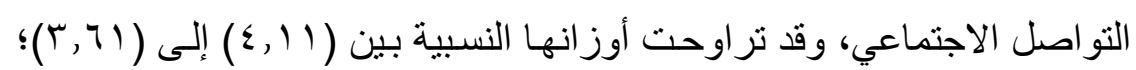
ويمكن أن يرجع ذلك إلى النزعة الإسـلامية التي يتصف بهـا أبنـاء دول العـالم

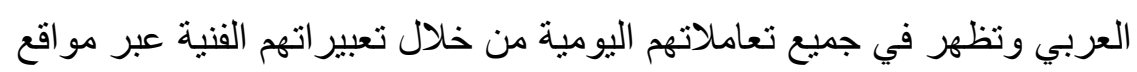

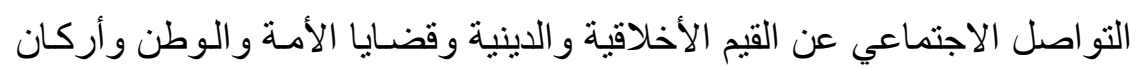

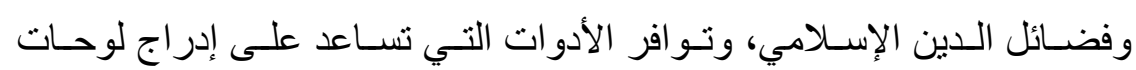
وعناصر خارجية مختلفة الامتداد على هذه المو اقع. 
دور مواقع التواصل الاجتماعي في تحقيق أهداف التربية الفنية والاتجاهات نحوها لاى طلاب المرحلة الثانوية

جدول (o)

اللهدف الثاني: الإتتاج القني

التكرارات والنسب والوزن النسبي والانحر جف المعياري ومستوى الموافقة المرتبطة

بدور مواقع التواصل الاجتماعي في تحقيق الإنتاج القني لدى طلاب المرحلة الثانوية

\begin{tabular}{|c|c|c|c|c|c|c|c|c|c|c|c|c|c|c|}
\hline \multirow{3}{*}{ 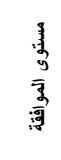 } & \multirow{3}{*}{ 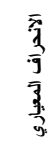 } & \multirow{3}{*}{ 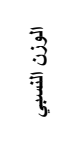 } & \multicolumn{10}{|c|}{ مستوى الموافقة } & \multirow{3}{*}{ العبارة } & \multirow{3}{*}{ c } \\
\hline & & & \multicolumn{2}{|c|}{ أرفض بشدة } & \multicolumn{2}{|c|}{ أرفض } & \multicolumn{2}{|c|}{ محايد } & \multicolumn{2}{|c|}{ هوافق } & \multicolumn{2}{|c|}{ موافق بشدة } & & \\
\hline & & & $\%$ & s & $\%$ & ك & $\%$ & s & $\%$ & ك & $\%$ & s & & \\
\hline & & & & & & & & & & & & & \multicolumn{2}{|c|}{ تساعدني مواقع التواصل الاجتماعي على أن: } \\
\hline موافقي & $\cdot$ - vo & $\varepsilon, r$ & - & - & - & - & ra, & ra & $r 9,9$ & 09 & $\lfloor\cdot$, & 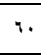 & المفتمتع بإنتاج بعض الأعمال الفنية & 1 \\
\hline موافق & $\cdot, 99$ & $r, q v$ & r & $r$ & $\curlyvee, \wedge$ & 1. & $i v, \uparrow$ & ry & ra,r & ox & $r \leqslant, 0$ & 01 & 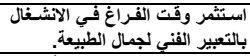 & $v$ \\
\hline موافق & 1,11 & $r, v$. & $r, \cdot$ & $r$ & $1 \&, r$ & r & $r^{4}, \varepsilon$ & ra & $r v,$. & ؛ & $r \cdot, \xi$ & $\leqslant 0$ & الفنتية علثيها الفيرصها. لعـرض الأعمـال & $\wedge$ \\
\hline موافق & $\cdot, 9$. & $r, v r$ & $r, \cdot$ & $r$ & $\varepsilon, \mathrm{v}$ & $\mathrm{v}$ & $\mathrm{r}, \Lambda$ & $\varepsilon v$ & $\leqslant 1,9$ & ir & 19,4 & ra & 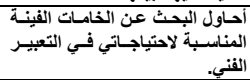 & a \\
\hline موافق & $\cdot, 99$ & $\leqslant, 1$. & $r,$. & $r$ & $\varepsilon, V$ & $v$ & $i v, r$ & is & $r r, \xi$ & $\varepsilon \wedge$ & $r r, r$ & $7 \leqslant$ & 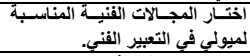 & 1. \\
\hline موافق & $\cdot, \mathrm{TV}$ & $r, 9 \leqslant$ & \multicolumn{2}{|c|}{$\frac{14}{14}$} & \multicolumn{2}{|c|}{ «o } & \multicolumn{2}{|c|}{$17 \mathrm{~V}$} & \multicolumn{2}{|c|}{ YIV } & \multicolumn{2}{|c|}{$r \leqslant 9$} & \multicolumn{2}{|l|}{ إجمالي الههف الثاني } \\
\hline
\end{tabular}

بالنظر إلى البيانات الإحصائية المفصلة لآر اء عينـة البحث من طلاب المرحلة

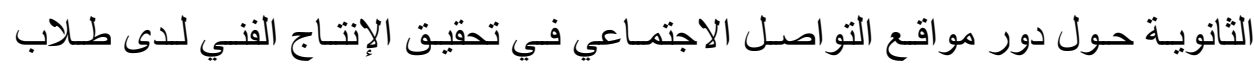
المرحلة الثانوية، بتضح ما بلي:

- - جاء الهدف الثاني الإنتاج الفني لاى طلاب المرحلة الثنانوية في الكويت عند مستوى

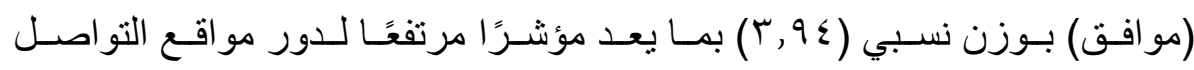
الاجتماعي في تحقيق الإنتاج الفني لدى طلاب المرحلة الثنانوية. - - جاءت جميع مؤشرات الهدف الثاني الإنتاج الفني لدى طلاب المرحلة الثانويـة عند

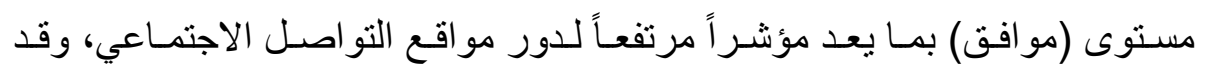

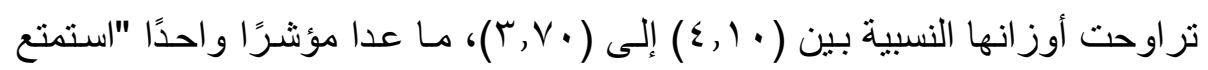

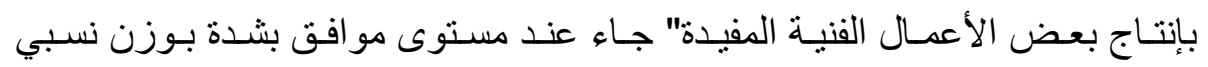

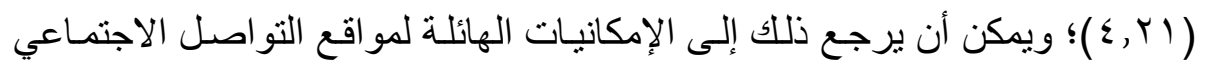
التي تتيح للطالب استثمار وقت الفراغ في البحث عن الخامـات المناسـبة لإنتاج 
د/ بثينة عبد الله الملا

الأعمال الفنية المناسبة لميولهه و المفيدة للمجتمع، وتسويقها عبر هذه المواقع لكثرة عدد المشتركين بها. الهدف الثالث: التذوق الفني

جدول (7) (7)

التكرارات والنسب والوزن النسبي والاتحراف المعياري ومستوى المولي الموافقة المرتبطة

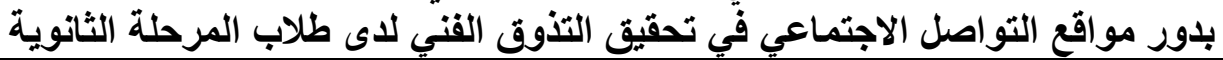

\begin{tabular}{|c|c|c|c|c|c|c|c|c|c|c|c|c|c|c|}
\hline \multirow{3}{*}{$\begin{array}{l}\text { 芧 } \\
\text { 产 } \\
\text { 票 }\end{array}$} & \multirow{3}{*}{$\begin{array}{l}\frac{\bar{a}}{3} \\
\frac{3}{\bar{g}} \\
\frac{3}{3}\end{array}$} & \multirow{3}{*}{$\begin{array}{l}\overline{3} \\
3 \\
\overline{3} \\
\text { 年 }\end{array}$} & \multicolumn{10}{|c|}{ مستوى الموافقة } & \multirow{3}{*}{ العبارة } & \multirow{3}{*}{ P } \\
\hline & & & \multicolumn{2}{|c|}{ أرفض بشدة } & \multicolumn{2}{|c|}{ 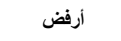 } & \multicolumn{2}{|c|}{ 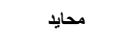 } & \multicolumn{2}{|c|}{ 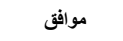 } & \multicolumn{2}{|c|}{ موافق بشدة } & & \\
\hline & & & $\%$ & s & $\%$ & ك & $\%$ & s & $\%$ & S & $\%$ & ك & & \\
\hline & & & & & & & & & & & & & \multicolumn{2}{|c|}{ تساعدني مواقع التّواصل الاجتماعي على أن: } \\
\hline 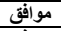 &., $9 \varepsilon$ & $r, 01$ & $r, \cdot$ & $r$ & $\Lambda, 1$ & Ir & $\varepsilon r, q$ & 70 & $r 9,1$ & $\varepsilon r$ & 19,9 & ro & أتعرف على فلسفة الفن. & 11 \\
\hline موافق & $\cdot, \mathrm{v}_{0}$ & $r, 9 \leqslant$ & $r, \cdot$ & $r$ & $r, \mathrm{r}$ & $\varepsilon$ & $1,, \Lambda$ & 14 & $\$ \Lambda, Y$ & 1.1 & 17,4 & $r \xi$ & أتعرف على أهمية الفن في حياة الفرد & IY \\
\hline موافق &., 99 & $r, \mathrm{VV}$ & $r, \cdot$ & $T$ & 11,0 & IV & $18, Y$ & $r \varepsilon$ & $\xi \wedge, \cdot$ & $\mathrm{vi}$ & KY, & $r T$ & أتثرب على مقومات الععل الفني. & 14 \\
\hline مبشدة & $\cdot, 1 \wedge$ & $\varepsilon, r v$ & - & - & - & - & 11,0 & iv & $r q, 9$ & .9 & $\{\Lambda, \uparrow$ & vi & 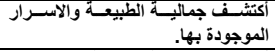 & $1 \leqslant$ \\
\hline مبشدة & -, 94 & $\varepsilon, Y \varepsilon$ & $r, \cdot$ & $r$ & $\cdot, \mathrm{v}$ & 1 & 11,9 & ra & $r \Lambda, \xi$ & $\varepsilon r$ & $\circ$ & $v \varepsilon$ & ألفنية. بين جمائية الطبيعة والابداعات & 10 \\
\hline 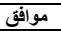 &., 04 & $r, 94$ & & \multicolumn{2}{|c|}{$r \varepsilon$} & \multicolumn{2}{|c|}{10.} & & & \multicolumn{2}{|c|}{ TYA } & \multicolumn{2}{|l|}{ إجمالي متوسط الهاف الثالث } \\
\hline
\end{tabular}

بالنظر إلى البيانات الإحصائية المفصلة لآر اء عينـة البحث من طلاب المرحلة الثانويـة حـول دور مو اقع التواصـل الاجتمـاعي في تحقيق التـذوق الفنـي لـدى طـلاب المرحلة الثانوية، يتضح ما يلي: - - جاء الهدف الثالث التذوق الفني لدى طلاب المرحلة الثانويـة في الكويت عند

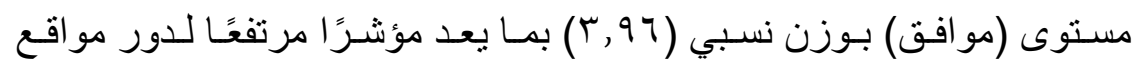
التواصل الاجتماعي في تحقيق الإنتاج الفني لدى طلاب المرحلة الثانوية. - جاءت معظم مؤشر ات الهدف الثالث التذوق الفني لدى طلاب المرحلة الثانويـة عند مستوى (مو افق) بما يعد مؤشراً مرتفعـاً لدور مواقع التو اصل الاجتمـاعي،

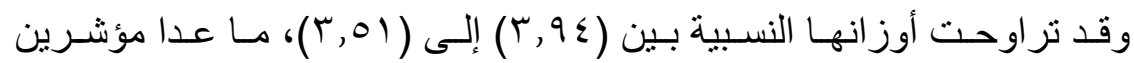

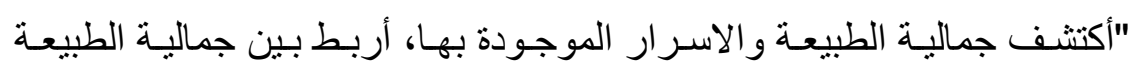

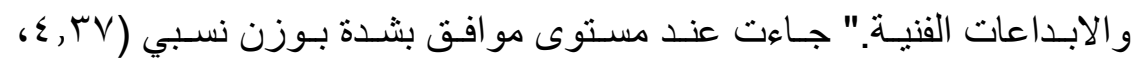

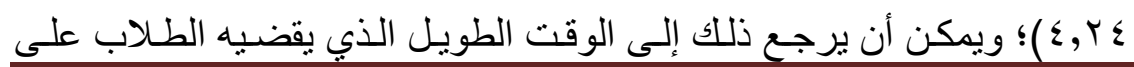


دور مواقع التواصل الاجتماعي في تحقيق أهداف التربية القنية والاتجاهات نحوها لاى طلاب المرحلة الثانوية

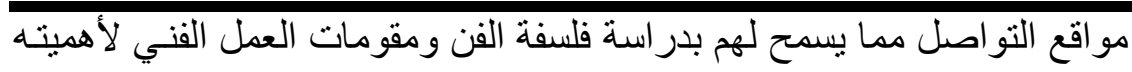
في حياة الفرد لاكتشـاف جمالية الطبيعة والأسر ار الموجودة بها و الربط بينها وبين الابداعات الفنية للطلاب.

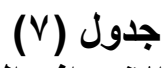

الهزف الرابع: تاريخ الفن

التكرارات والنسب والوزن النسبي والانحرافت المعياري ومستوى الموافي لقافقة المرتبطة بلدور مواقع التو اصل الاجتماعي في تحقيق تاريخ الفن لاى طلاب المرحلة الثانوية

\begin{tabular}{|c|c|c|c|c|c|c|c|c|c|c|c|c|c|c|}
\hline \multirow{3}{*}{ 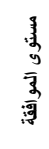 } & \multirow{3}{*}{ 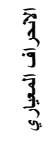 } & \multirow{3}{*}{$\begin{array}{l}\overline{3} \\
\overline{3} \\
\overline{3}\end{array}$} & \multicolumn{10}{|c|}{ مستوى الموافقة } & \multirow{3}{*}{ 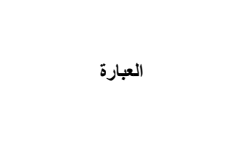 } & \multirow{3}{*}{ م } \\
\hline & & & \multicolumn{2}{|c|}{ أرفض بشدة } & \multicolumn{2}{|c|}{ أرفض } & \multicolumn{2}{|c|}{ 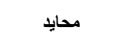 } & \multicolumn{2}{|c|}{ موافق } & \multicolumn{2}{|c|}{ موافق بثدة } & & \\
\hline & & & $\%$ & s & $\%$ & s & $\%$ & ك & $\%$ & S & $\%$ & s & & \\
\hline & & & & & & & & & & & & & \multicolumn{2}{|c|}{ تساعدني مواقع التواصل الاجتماعي على أن: } \\
\hline موافق & • & $\varepsilon,+1$ & - & - & $r, v$ & $\varepsilon$ & $r \bullet, v$ & rs & rq, १ & $\Delta q$ & $r_{1, \Lambda}$ & $\varepsilon v$ & 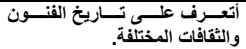 & 17 \\
\hline موافق & $\cdot, \Lambda Y$ & $\varepsilon, \cdot r$ & $r, \cdot$ & $r$ & - & - & 19,7 & rq & $\leqslant 9, r$ & VT & rq, & $\varepsilon r$ & أُقوم بإثراء الفكر الفني من خلالها. & IV \\
\hline موافق & 1,1 . & $r, v i$ & $\varepsilon, v$ & $\mathrm{v}$ & $\wedge, \wedge$ & it & Tr, & ro & rч, & $0 \leqslant$ & $r q, \varepsilon$ & ra & خلالهـاف على المــارس الفنيـة مـن & 11 \\
\hline موافق & $\cdot, \mathrm{TH}$ & $r, 91$ & \multicolumn{2}{|c|}{1.} & & & \multicolumn{2}{|c|}{$1 . r$} & & & \multicolumn{2}{|c|}{$1 \times 9$} & \multicolumn{2}{|l|}{ إجمالي الهذف الرابع } \\
\hline
\end{tabular}

بالنظر إلى البيانات الإحصائية المفصلة لآراء عينـة البحث من طلاب المرحلة

الثانوية حول دور مو اقع التواصل الاجتماعي في تحقيق تاريخ الفن لدى طلاب المرحلة

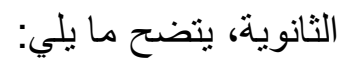

- - جاء الهدف الرابع تاريخ الفن لدى طلاب المرحلـة الثانويـة في الكويت عند مستوى

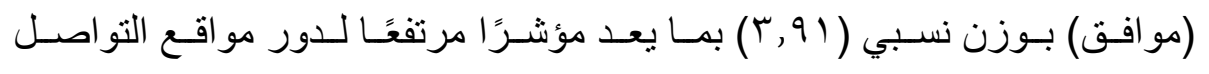
الاجتماعي في تحقيق تاريخ الفن لدى طلاب المرحلة الثانوية.

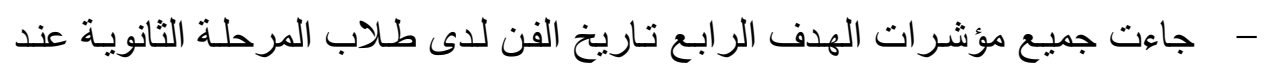

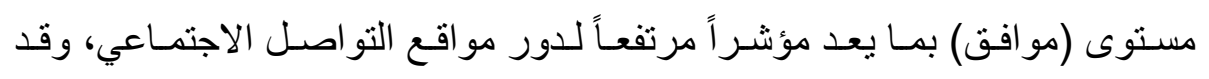

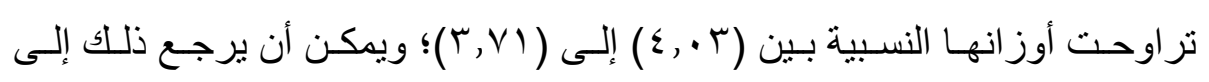
المنتديات الفنية التي تجمع بين أفراد من مختلف الثقافات، وتتوافر بها التهات التوحات الفنية التي تعبر عن تاريخ الفن وثقافاته ومدارسه المختلفة لإثراء الفكر الفني. 
جدول (^)

الهذف الخامس: النقل الفني

التكرارات والنسب والوزن النسبي والانحراف المعياري ومستوى الموافقة المرتبطة بدور مواقع التواصل الاجتماعي في تحقيق النقا الفني لاى طلاب المرحلة الثانوية

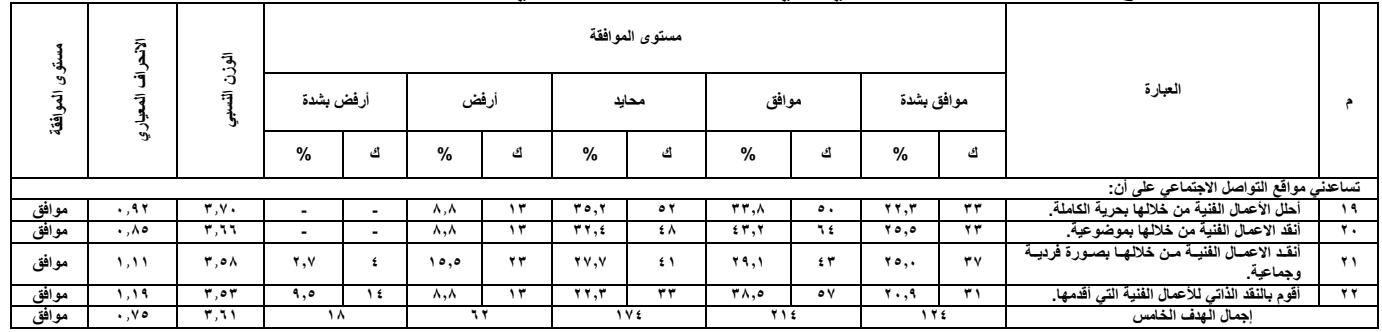

بالنظر إلى البيانات الإحصائية المفصلة لآر اء عينـة البحث من طلاب المرحلة

الثانوية حول دور مو اقع التواصل الاجتماعي في تحقيق النقد الفني لدى طلاب المرحلة

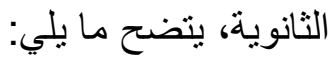

- - جـاء الهدف الخـامس النقد الفني لدى طلاب المرحلـة الثانويـة في الكويت عند

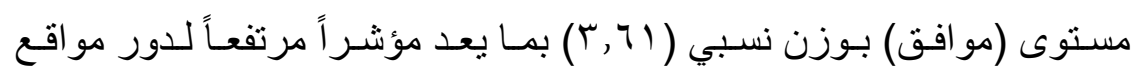
التواصل الاجتماعي في تحقيق النقد الفني لدى طلاب المرحلة الثانوية. - جاءت جميع مؤشرات الهـف الخـامس النقد الفني لدى طلاب المرحلة الثانويـة عند مستوى (مو افق) بما يعد مؤشرًا مرتفعَا لدور مواقع التو اصل الاجتمـاعي،

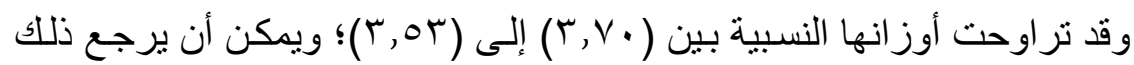
إلى المنتـيات الفنيـة على مواقع التواصل الاجتمـاعي لعـرض الأعمـال الفنيـة و التي تسمح بتحليل الاعمـال الفنية ونقدها بموضو عية سواء بصورة فرديـة أو

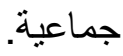


لدور مواقع التو اصل الاجتماعي في تحقيق أهداف التربية الفنية والاتجاهات نحوها لاى طلاب المرحلة الثانوية

الههف السادس: التواصل القني

جدول (9)

التكرارات والنسب والوزن النسبي والانحراف المعياري ومستوى المولي الموافي افقة المرتبطة

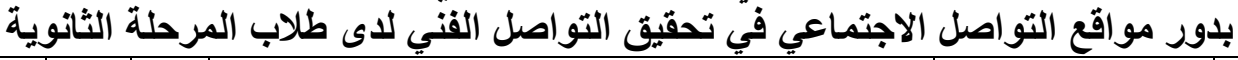

\begin{tabular}{|c|c|c|c|c|c|c|c|c|c|c|c|c|c|c|}
\hline \multirow{3}{*}{ 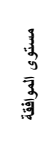 } & \multirow{3}{*}{$\begin{array}{l}\frac{5}{3} \\
\frac{3}{3} \\
\frac{3}{3}\end{array}$} & \multirow{3}{*}{ 高 } & \multicolumn{10}{|c|}{ مستوى الموافقة } & \multirow{3}{*}{ العبارة } & \multirow{3}{*}{ p } \\
\hline & & & \multicolumn{2}{|c|}{ أرفض بشدة } & \multicolumn{2}{|c|}{ 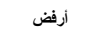 } & \multicolumn{2}{|c|}{ محايث } & \multicolumn{2}{|c|}{ موافق } & \multicolumn{2}{|c|}{ موافق بشدة } & & \\
\hline & & & $\%$ & s & $\%$ & ق & $\%$ & 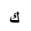 & $\%$ & ث & $\%$ & ث & & \\
\hline 26 & & 5 & 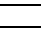 & 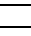 & 40 & 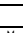 & 199 & 4 & $\Rightarrow$ & 7 & $4 y^{\prime}$ & 20 & 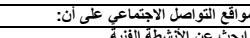 & تصاء \\
\hline موافظى & 1,10 & 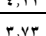 & $\gamma, \wedge$ & 1. & $r$ & $r$ & 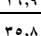 & or & $r, r, r$ & $r$ & $\frac{m-1}{m+1}$ & 39 & 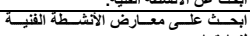 & it \\
\hline موافق &., $9 \mathrm{v}$ & $r, \mathrm{VA}$ & $r, \cdot$ & $r$ & $\gamma, \wedge$ & 1. & $r_{\wedge, q}$ & $\leqslant r$ & $r \mathrm{r}, \mathrm{r}$ & 0 & $r o, v$ & $r_{\Lambda}$ & اتواصل من خلال منتكياتهيا مع الزملاء بما & io \\
\hline موافق &., $9 \wedge$ & $r, v$, & r,. & $r$ & 11,0 & iv & 19,7 & ra & $\leqslant v, r$ & $v$. & 19,4 & ra & 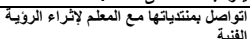 & r \\
\hline موافقت & $\cdot, \wedge_{0}$ & $r, \uparrow$ & $r, \cdot$ & 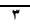 & $\mathrm{v}, \mathrm{\xi}$ & 11 & $r v, \cdot$ & ؛ & 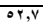 & $\mathrm{VA}$ & $1 \cdot, \lambda$ & 17 & 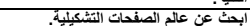 & TY \\
\hline مهوافقى & $1, .4$ & $r, \Delta v$ & $r, \cdot$ & $r$ & $\mathrm{v}, \mathrm{\varepsilon}$ & "1 & $r 0, \Lambda$ & or & $r a, v$ & 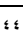 & $r, r$ & re & 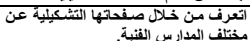 & iA \\
\hline 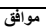 & $\cdot, \mathrm{Vr}$ & $r, v_{0}$ & & & & & & & & & & & إجمال الهيف السانس & \\
\hline
\end{tabular}

بالنظر إلى البيانات الإحصائية المفصلة لآراء عينة البحث من طلاب المرحلة

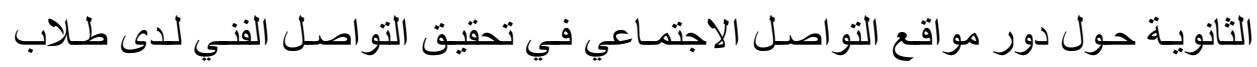

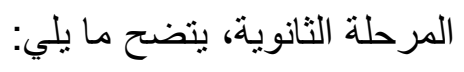

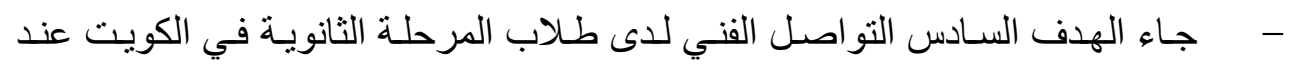
مستوى (موافق) بوزن نسبي ( (T, ب) بمـا يعد مؤشرًا مرتفعًا لدور مواقع التو اصل الاجتماعي في تحقيق التواصل الفني لدى طلاب المرحلة الثانوية.

- جاءت جميع مؤشرات الهدف السـادس التو اصل الفني لدى طلاب المرحلة الثانويـة عند مستوى (مو افق) بمـا يعد مؤشترًا مرتفعًا لدور مواقع التو اصل الاجتمـاعي، وقد

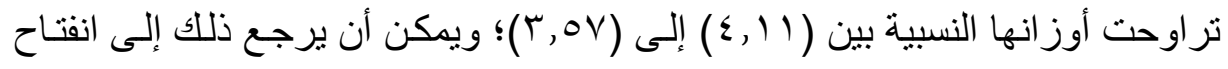

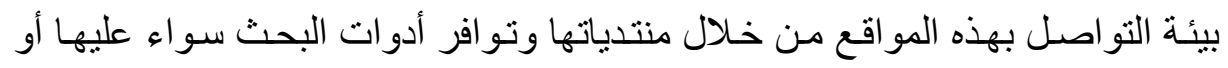
على الانترنت مما يتيح آلية البحث عن الأنثطة الفنيـة والتشكيلية و أثثر اء الرؤيـة الفيـة من خلال اختلاف أصحاب المدارس الفنية بها. 
د/ بثينة عبد الله الملا

استبانة دور مواقع التواصل الاجتماعي في تحقيق أهداف التربية الفنية جدول (· · 1)

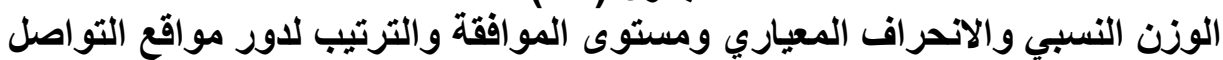

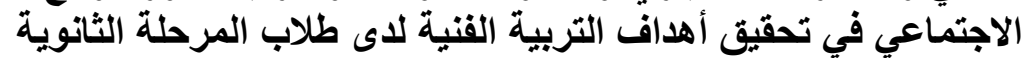

\begin{tabular}{|c|c|c|c|c|}
\hline التزتيب & الموافقة & الانحرافياري & النسبي & 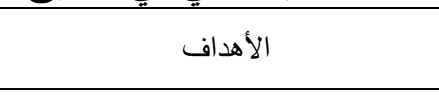 \\
\hline 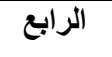 & 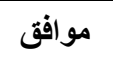 & $\cdot, 77$ & $r, \wedge \mathrm{r}$ & الهـف الأول: الهوية والانتماء الوطني \\
\hline الثاني & 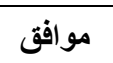 & $\cdot, 7 \mathrm{~V}$ & $r, q \leq$ & الهدف الثاني: الإتتاج الفني \\
\hline الأول & 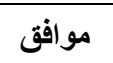 & $\cdot$, or & r, 94 & الهُف الثالث: التذوق الفني \\
\hline 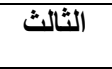 & 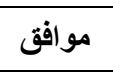 & • & $r, q 1$ & الهذف الرابع: تاريخ الفن \\
\hline السنادس & 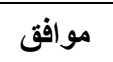 & $\cdot, v_{0}$ & $r, 71$ & الهُف الخامس: النقد الفني \\
\hline 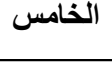 & 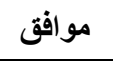 & $\cdot, \mathrm{Vr}$ & $r, v_{0}$ & الهدف السادس: التواصل الفني \\
\hline & موافق & $\cdot, 01$ & $r, \wedge ⿻$ & اجمالي الاستبانة \\
\hline
\end{tabular}

ومن خلال تحليل آراء عينـة البحث الحسالي من طلاب المرحلة الثانويـة يتضـح

الدور الإيجابي لمواقع التواصل الاجتمـاعي في تحقيق أهداف التربية الفنيـة لدى طلاب المرحلة الثانوية، وتظهر النتائج أن: أعلى الأهداف من حيث التأثر بدور مواقع التواصل لتصل الاجتمـاعي يتمثل في الهدف الثالث: التذوق الفني عند مستوى مرتفع (موافق) بوزن نسبي (†,97)، يليه الهدف الثاني: الإنتاج الفني عند مستوى مرتفع (موافق) بوزن نسبي

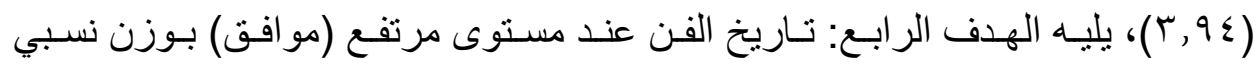
(1), (r, يليه الهدف الأول: الهوية و الانتماء الوطني عند مستوى مرتفع (موافق) بوزن

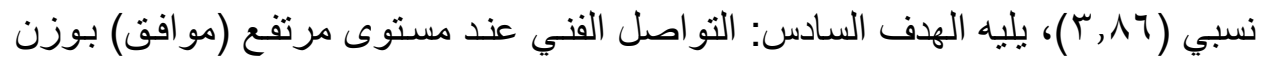
نسبي (r,V0)، يليه الهدف الخامس: النقد الفني عند مستوى مرتفع (مو افق) بوزن نسبي

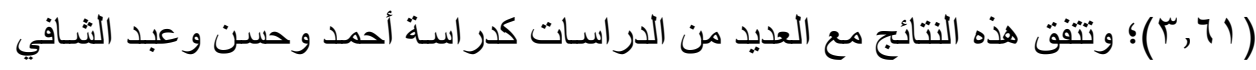
(Y) التي توصلت إلى الدور الإيجابي لمواقع التواصل الاجتماعي ومنها اليوتيوب

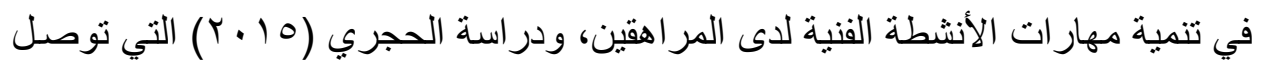
إلى الدور الإيجابي لتوظيف بعض شبكات التو اصل الاجتمـاعي (الانستجر ام ويوتيوب) 
دور مواقع التواصل الاجتماعي في تحقيق أهداف التربية الفنية والاتجاهات نحوها لاى طلاب المرحلة الثانوية

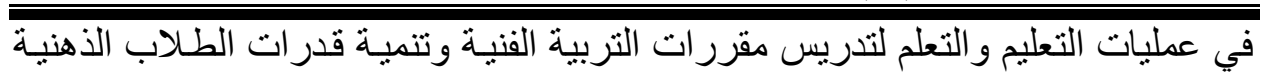

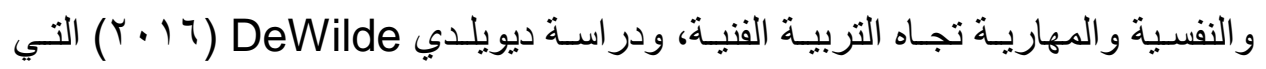
توصـلت إلى أن معلمسي الفنـون يسـتخدمون مواقـع التواصـل الاجتمـاعي كـأداة لقصـولهم الدراسية بينما الأغلبية بستخدم تطبيقات مواقع التو اصل الاجتمـاعي للعثور على الأفكار و الإلهـام في التربيـة الفنيـة، ودر اسـة محمد ( 99 ( ) التي توصـلت إلى فاعليـة استخدام المدخل التكنولوجي في تحقيق بعض أهداف التربية الفنية.

\section{ثانياً: نتائج مقياس الاتجاه نحو التربية الفتية}

تتــاول النتـائج التاليـة عرضنَا مفصـلَا لآراء عينـة البحـث مـن طـلاب المرحلـة

الثانويـة بدولـة الكويت حول محساور المقيـاس الثلاثة، وذلك للإجابـة على سؤال البحث. الثالث، ليتتم الكثـف عن مسـتوى الموافقة على اتجاهـات طـلاب المرحلـة الثانويـة نحـو التربية الفنية في ضـوء دور مو اقع التو اصل الاجتمـاعي من وجهة نظر هم، وفيمـا يلي النتائج بصورة مفصلة.

ينص السؤال الثالث على: ما اتجاهات طلاب الثرات التهلة الثانوية نحو التربية الفنيـة نتائج السؤال الثالث:

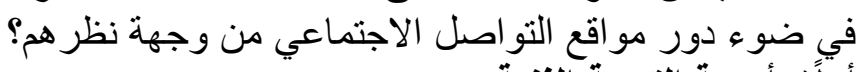

\section{جدول (1) (1) (1)}

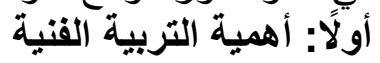

التكرارات والنسب والوزن النسبي والانحراف المعياري ومستوى والموافقة المرتبطة

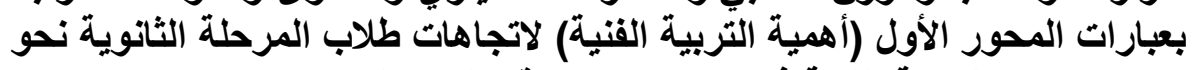

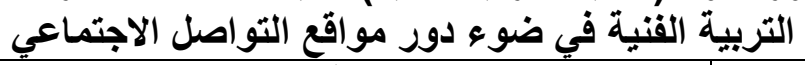

\begin{tabular}{|c|c|c|c|c|c|c|c|c|c|c|c|c|c|c|}
\hline \multirow{3}{*}{ 量高 } & \multirow{3}{*}{$\frac{\overline{1}}{\frac{1}{3}} \frac{\overline{3}}{9}$} & \multirow{3}{*}{$\begin{array}{l}\overline{3} \\
. \overline{3} \\
\overline{7} \\
\end{array}$} & \multicolumn{10}{|c|}{ مسنتوى المو افقةً } & \multirow{3}{*}{ العبارة } & \multirow{3}{*}{ s } \\
\hline & & & \multicolumn{2}{|c|}{ أرفض بشدة } & \multicolumn{2}{|c|}{ أرفض } & \multicolumn{2}{|c|}{ محايد } & \multicolumn{2}{|c|}{ مو افق } & \multicolumn{2}{|c|}{ مو مافق بشدة } & & \\
\hline & & & $\%$ & كs & $\%$ & ك & $\%$ & كs & $\%$ & ك & $\%$ & s & & \\
\hline & & & & & & & & & & & & & يمو اقع الثتو اصل الاجتماعي على أن: & تساء \\
\hline مواف & . 9 १ & 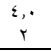 & - & - & $1 \cdot, 1$ & 10 & $I_{T}, \mathrm{r}$ & in & $\begin{array}{c}\varepsilon r \\
r\end{array}$ & $T \varepsilon$ & $r \varepsilon, 0$ & 01 & جميع المر احهل الدراسية. وجود التزبية الفنية في & 1 \\
\hline 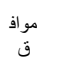 & $1, \cdot \mathrm{V}$ & $\begin{array}{c}r, 7 \\
1\end{array}$ & $r, r$ & $\varepsilon$ & 11,0 & iv & rq, & $\varepsilon r$ & $\stackrel{r .,}{\varepsilon}$ & $\varepsilon_{0}$ & $\mathrm{r}_{\mathrm{q}, \varepsilon}$ & rq & 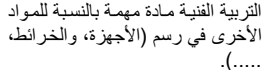 & r \\
\hline مو اف & 1,11 & $\begin{array}{c}r, 4 \\
\vdots \\
\end{array}$ & $r, \varepsilon$ & . & $1 A, r$ & rv & $1 \wedge, 9$ & rA & $\begin{array}{c}r \cdot, \\
\vdots\end{array}$ & $\varepsilon_{0}$ & $r q, 1$ & $\varepsilon r$ & الجامعية. & r \\
\hline مو & . 70 & $\begin{array}{c}\varepsilon, 0 \\
\Lambda\end{array}$ & 1, & r & - & - & $\cdot, \mathrm{v}$ & 1 & ro, & or & $r, \wedge$ & qr & بجمال الطبيعة. الفنية مفيدة في الإحساس & $\varepsilon$ \\
\hline
\end{tabular}

العدد الخامس والاربعون (الجزء الثانى) ا ب r r

(520)

مجلة كلية التربية- جامعة عين شمس 
د/ بثينة عبد الله الملا

\begin{tabular}{|c|c|c|c|c|c|c|c|c|c|c|c|c|c|c|}
\hline \multirow{3}{*}{ 衰高 } & \multirow{3}{*}{$\frac{7}{3}$} & \multirow{3}{*}{$\begin{array}{l}\overline{3} \\
\overline{3} \\
\overline{7} \\
\bar{j}\end{array}$} & \multicolumn{10}{|c|}{ مستوى المو افقّة } & \multirow{3}{*}{ العبارة } & \multirow{3}{*}{ P } \\
\hline & & & \multicolumn{2}{|c|}{ أرفض بشدة } & \multicolumn{2}{|c|}{ 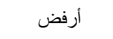 } & \multicolumn{2}{|c|}{ محايد } & \multicolumn{2}{|c|}{ موافق } & \multicolumn{2}{|c|}{ مو افق بشدة } & & \\
\hline & & & $\%$ & ك & $\%$ & ك & $\%$ & ك & $\%$ & كs & $\%$ & ك & & \\
\hline 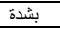 & & & & & & & & & & & & & & \\
\hline مو فاف & $\cdot, 9 \leqslant$ & $\begin{array}{l}\varepsilon_{0} \\
0\end{array}$ & $1, \varepsilon$ & r & $\mathrm{v}, \varepsilon$ & 11 & $1 \cdot, \wedge$ & 17 & $\begin{array}{c}\text { @o, } \\
9\end{array}$ & 71 & $r \varepsilon, 0$ & 01 & ألدقة في العمبة التربية الفنبة في اكتساب & 。 \\
\hline مواف & $\cdot, 90$ & 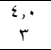 & $1, \varepsilon$ & r & $\lambda, 1$ & ir & $1 \cdot, \wedge$ & 17 & $\stackrel{4}{r}$ & TV & $r \leqslant, 0$ & 01 & 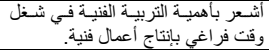 & 7 \\
\hline مواف & $1, .4$ & $\begin{array}{c}r, 9 \\
1\end{array}$ & $r, V$ & $\varepsilon$ & 9,0 & $1 \varepsilon$ & 10,0 & ז & $\begin{array}{c}r \Lambda, \\
\circ\end{array}$ & or & $r r, \Lambda$ & o. & 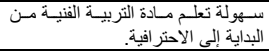 & v \\
\hline مقو & $\cdot, \mathrm{v}$ & $\varepsilon, \varepsilon$ & - & - & $\cdot, v$ & 1 & $1 ., 1$ & 10 & rq, & $0 \leqslant$ & Or,Y & $\mathrm{VA}$ & تخصصية. أري مـادة التربية الفنيـة كمـادة هو ايات & $\wedge$ \\
\hline محايد & 1,19 & $r, r$ & $\wedge, \wedge$ & it & $i r, \Lambda$ & 19 & $\Gamma \wedge, 0$ & or & $\begin{array}{l}11, \\
9\end{array}$ & rA & $r \cdot, 9$ & ri & ألهيتية التربيـة الفنية في ترتيب الأمور & 9 \\
\hline 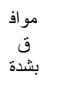 & - & $\begin{array}{l}\varepsilon, Y \\
\varepsilon\end{array}$ & $1, \varepsilon$ & r & $\varepsilon, 1$ & 7 & $\varepsilon, 1$ & 7 & $\ddot{0}$, & vo & $r q, q$ & 09 & 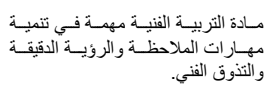 & 1. \\
\hline مو افو & אזו, & $\begin{array}{c}r, 9 \\
1\end{array}$ & \multicolumn{2}{|c|}{ T } & \multicolumn{2}{|c|}{ irt } & \multicolumn{2}{|c|}{ rrt } & \multicolumn{2}{|c|}{000} & \multicolumn{2}{|c|}{$0 \leqslant 7$} & \multicolumn{2}{|l|}{ إجمالي المحور الأول } \\
\hline
\end{tabular}

بالنظر إلى البيانات الإحصائية المفصلة لآراء عينة البحث مـن طـلاب المرحلة الثانويـة حول أهميـة التربيـة الفنيـة كمحور أول لاتجاهـات طلاب المرحلـة الثانويـة نحو التربية الفنية في ضوء دور مواقع التواصل الاجتماعي، يتضح ما يلي: ـ جاء المحور الأول لاتجاهات طلاب المرحلة الثانويـة نحو التربيـة الفنيـة (أهميـة

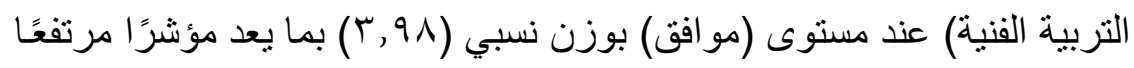
لدور مواقع التو اصل الاجتماعي في تتمية أهمية طلاب المرحلة الثانوية بالتربية الفنبة. - جـاءت ثنلاث مؤشر ات بـالمحور الأول لاتجاهـات طلاب المرحلة الثانويـة نحو التربية الفنية (أهمية التربية الفنيـة) عند مستوى (موافق بشدة) بمـا بعد مؤشراً مرتفعاً جداً لدور مواقع التواصل الاجتماعي، وقد تراوحت أوزانها النسبية بين

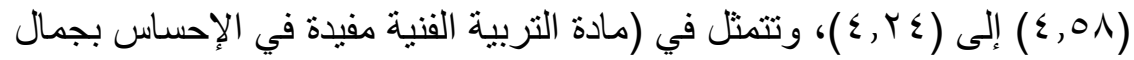
الطبيعة، أري مـادة التربيـة الفنيـة كمـادة هو ايـات تخصصية، مـادة التربيـة القنيـة مهمة في تنمية مهار ات الملاحظة والرؤية الدقيقة و التذوق الفني). 
دور مواقع التواصل الاجتماعي في تحقيق أهداف التربية الفنية والاتجاهات نحوها لاى طلاب المرحلة الثانوية

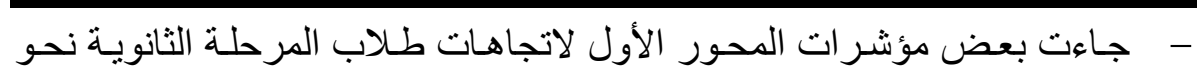

التربية الفنية (أهمية التربية الفنية) عند مستوى (مو افق) بما يعد مؤشراً مرتفعـاً

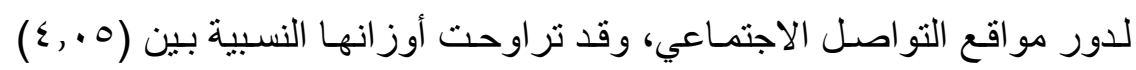

$$
\text { إلى ( ) ( }
$$

- جاء مؤشراً واحد بالمحور الأول لاتجاهات طلاب المرحلة الثانويـة نحو التربيـة الفنية (أهمية التربية الفنية) عند مستوى (محايد) بما يعد مؤشرًا متوسط لدور

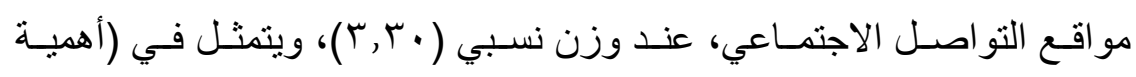
التربية الفنية في ترتيب الأمور الحياتية الخاصة بي).

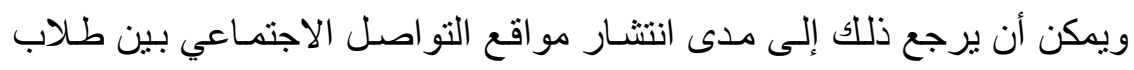
المرحلـة الثانويـة من مختلف الفئات و الثقافـات، ومدى تنو عهـا، ورفع مستوى الأدوات و الامكانيات الموجودة بها، مما ييسر على الطلاب على الإحسـاس بجمـال الطبيعة من لن

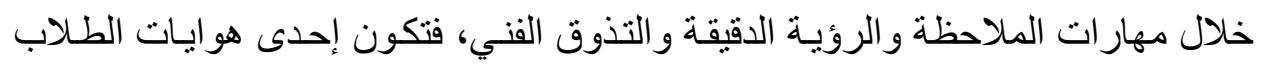
الاتي تسـاعدهم في استتمار وقت الفراغ في تلبيـة احتياجـات المو اد الأخرى من رسم الته الأجهزة و الخر ائط في جميع مر احل التعليم، حتى تتحول من هواية إلى احتر اف فئ.

\section{ثانيًا: تذوق محتوى مادة التربية الفنية}

\section{جدول (1)}

التكرارات والنسب والوزن النسبي والانحراف المعياري ومستوى والتوات والموافقة المرتبطة

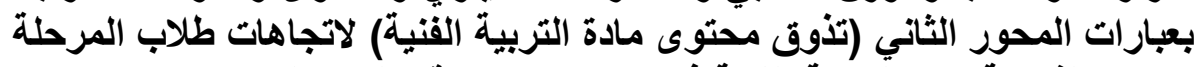

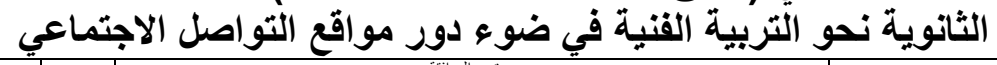

\begin{tabular}{|c|c|c|c|c|c|c|c|c|c|c|c|c|c|c|}
\hline \multirow{3}{*}{ 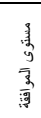 } & \multirow{3}{*}{ 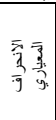 } & \multirow{3}{*}{$\begin{array}{l}\overline{3} \\
\overline{3} \\
\overline{9}\end{array}$} & \multicolumn{10}{|c|}{ مستوى الموا افقة } & \multirow{3}{*}{ 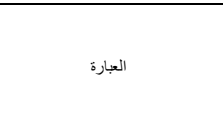 } & \multirow{3}{*}{ P } \\
\hline & & & \multicolumn{2}{|c|}{ أرضض بشدة } & \multicolumn{2}{|c|}{ 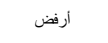 } & \multicolumn{2}{|c|}{ محايد } & \multicolumn{2}{|c|}{ 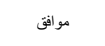 } & \multicolumn{2}{|c|}{ موا مق بشدة } & & \\
\hline & & & $\%$ & ك & $\%$ & $s$ & $\%$ & s & $\%$ & s & $\%$ & ك & & \\
\hline & & & & & & & & & & & & & مواقع التؤواصل الاجتماعي على أن: & تساء \\
\hline 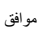 & $\cdot, 9$. & \&, & ।, & r & $\{, v$ & v & 11,0 & iv & $\varepsilon r, r$ & Is & $r q, r$ & ox & 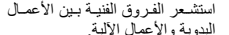 & "1 \\
\hline مبدافق & .90 & $\varepsilon, Y$ צ & ।,£ & r & $\varepsilon, y$ & v & $i r, \Lambda$ & 19 & $r_{\lambda, \varepsilon}$ & $\leqslant r$ & or,,$y$ & $\mathrm{v} \wedge$ & 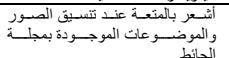 & ir \\
\hline موافق ل موافت & $1, \cdot \varepsilon$ & 8,17 & $0, \wedge$ & $\wedge$ & r,ई & 。 & $\varepsilon, v$ & v & $\varepsilon r, r$ & $\pi$ & $\overline{\varepsilon r, r}$ & $T \leqslant$ & 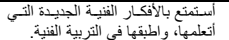 & ir \\
\hline م موافق & $\cdot, 94$ & $\varepsilon, \times 9$ & $\varepsilon, v$ & v & ـ & $r$ & $\xi, v$ & v & $r, 0$ & $0 \leqslant$ & $0 ., v$ & vo & مالجمادة التزبية الفنية تبعث لدى إحساس & Iः \\
\hline مبردافق & $1, \cdot \varepsilon$ & $\varepsilon, Y_{0}$ & $0, \xi$ & A & $r$, & $r$ & $0, \xi$ & $\wedge$ & $r q, 0$ & 0 o & $0 ., v$ & vo & 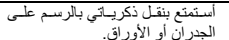 & 10 \\
\hline مبرافت & - זוז & $\varepsilon, \pi$ & - & - & - & - & - & - & $r r, 1$ & $\leqslant 9$ & 70,0 & qv & 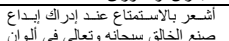 & 17 \\
\hline
\end{tabular}

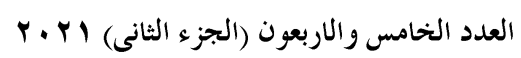

$(522)$

مجلة كلية التربية- جامعة عين شمس 
د/ بثينة عبد الله الملا

\begin{tabular}{|c|c|c|c|c|c|c|c|c|c|c|c|c|c|c|}
\hline \multirow{3}{*}{ 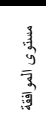 } & \multirow{3}{*}{$\frac{1}{3}$} & \multirow{3}{*}{$\begin{array}{l}\overline{3} \\
\overline{3} \\
\overline{1}\end{array}$} & \multicolumn{10}{|c|}{ مستوى المو القفة } & \multirow{3}{*}{ العبارة } & \multirow{3}{*}{ s } \\
\hline & & & \multicolumn{2}{|c|}{ أرفض بشدة: } & \multicolumn{2}{|c|}{ أرضض | (أرض } & \multicolumn{2}{|c|}{ محائ } & \multicolumn{2}{|c|}{ 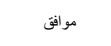 } & \multicolumn{2}{|c|}{ مو افق بشدة } & & \\
\hline & & & $\%$ & $s$ & $\%$ & ك & $\%$ & ك & $\%$ & ك & $\%$ & ك & & \\
\hline & & & & & & & & & & & & & الككون. & \\
\hline 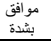 & $\cdot, \mathrm{r}$ & \&,or & $1, \varepsilon$ & $r$ &.,$v$ & 1 & $\varepsilon, v$ & v & $r, 1$ & $\varliminf_{0}$ & $T r, r$ & ar & 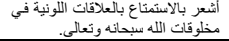 & iv \\
\hline بشدة & - ,9r & $\varepsilon, Y_{A}$ & $r, r$ & $\xi$ & $\cdot, \mathrm{v}$ & 1 & $1 \leqslant, r$ & $r$ & $r, 1$ & ז & $01, \xi$ & $\mathrm{VI}$ & 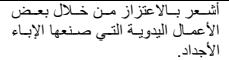 & is \\
\hline موافق & , 9 \& & $r, 9 r$ & - & - & $1 ., 1$ & 10 & $1 ., 1$ & 10 & or,. & v & $r \mathrm{r}, \xi$ & $r q$ & 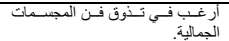 & 19 \\
\hline موافق & 1,17 & $\varepsilon, \cdot r$ & 7,1 & 9 & $0, \leqslant$ & $\wedge$ & $\overline{1 r, \xi}$ & $r$ r. & $r, \xi$ & @o & $\overline{\varepsilon, 7}$ & $\pi$ & 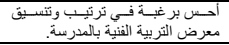 & $r$. \\
\hline 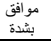 &., 79 & $\varepsilon, r_{0}$ & \multicolumn{2}{|c|}{ \&r } & \multicolumn{2}{|c|}{ ६9 } & \multicolumn{2}{|c|}{$m$} & \multicolumn{2}{|c|}{$0 \leqslant$. } & \multicolumn{2}{|c|}{ rr. } & \multicolumn{2}{|l|}{ إجمالي المحور الثاني } \\
\hline
\end{tabular}

بالنظر إلى البيانات الإحصائية المفصلة لآر اء عينـة البحث من طلاب المرحلة الثانوية حول تذوق محتوى مـادة التربيـة الفنية كمحور ثناني لاتجاهـات طلاب المرحلة الثانوية نحو التربية الفنية في ضوء دور مواقع التواصل الاجتماعي، يتضح ما يلي: - جاء المحور الثاني لاتجاهات طلاب المرحلة الثانويـة نحو التربيـة الفنية (تذوق محتوى مادة التربية الفنية) عند مستوى (مو افق بثدة) بوزن نسبي (ب0, ؟ ) بما يعد مؤشرًا مرتفعًا لدور مو اقع التواصل الاجتماعي في تنمية تذوق محتوى مادة التربية الفنبة لدى طلاب المرحلة الثانوية. - جـاءت معظم مؤشرات المحور الثناني لاتجاهـات طلاب المرحلة الثنانويـة نحو التربية الفنية (تذوق محتوى مادة التربية الفنية) عند مستوى (مو افق بشدة) بمـا

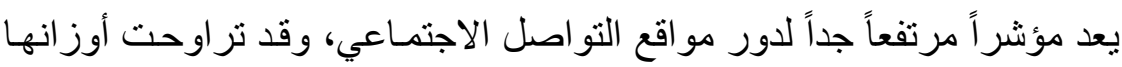

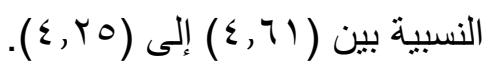

- جاءت ثناث مؤشر ات بـالمحور الأول لاتجاهـات طـلاب المرحلة الثانويـة نحو التربية الفنية (تذوق محتوى مـادة التربية الفنبة) عند مستوى (موافق) بما يعد مؤشرًا مرتفعًا لدور مواقع التواصل الاجتمـاعي، وقد تراوحت أوزانها النسبية

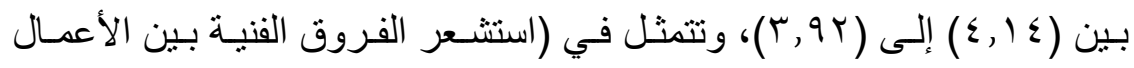
اليدوية والأعمال الآلية، أستمتع بالأفكار الفنية الجديدة التي أتعلمها، واطبقها في التي التربية الفنية، أرغب في تذوق فن المجسمات الجمالية، أحس برغبة في ترنيب وتتسيق معرض التربية الفنية بالمدرسة). 
دور مواقع التواصل الاجتماعي في تحقيق أهداف التربية الفنية والاتجاهات نحوها لاى طلاب المرحلة الثانوية

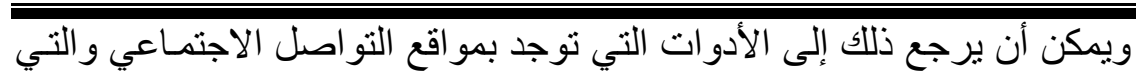
تمكن الطلاب من الرسم بصورة آلية ومقارنتها بالرسوم اليدويـة، بالإضـافة إلى تنسيق لوديق

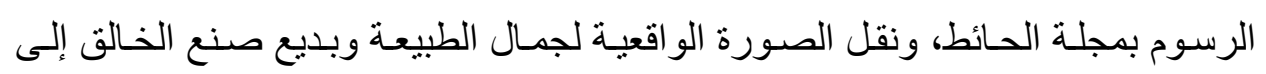
و اقع مرسوم على ورق، و إدر الك العلاقات اللونية في مخلوقات الله سبحانه وتعالى، ممـا يسهم في تذوق الفن بين جمال التصوير الآلي و الرسوم اليدوية.

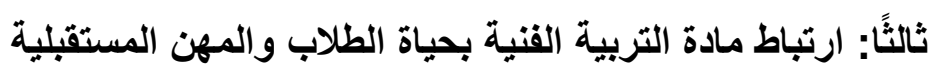

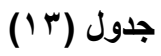

التكرارات والنسب والوزن النسبي والانحراف المعياري ومستوى والمواتواتواتة المرتبطة بعبارات المحور الثالث

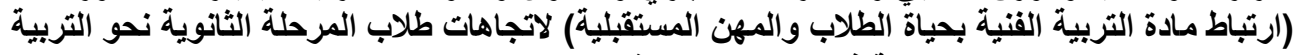

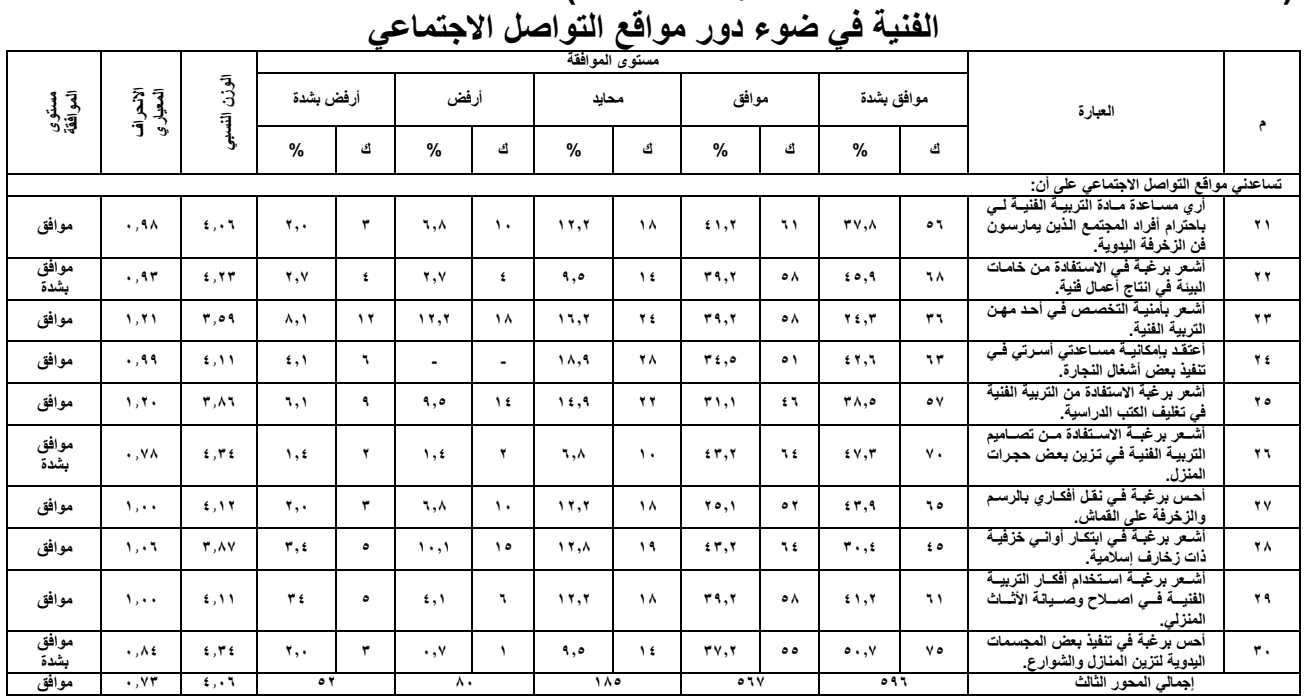

بالنظر إلى البيانات الإحصائية المفصلة لآراء عينـة البحث من طلاب المرحلة

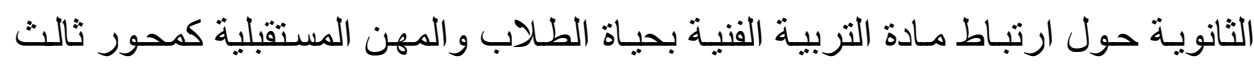
لاتجاهـات طـلاب المرحلـة الثانويـة نحو التربيـة الفنيـة في ضـوه دور مو اقع التواصـل الاجتماعي، يتضح ما يلي:

- جاء المحور الثالث لاتجاهات طلاب المرحلة الثانوية نحو التربية الفنية (ارتباط مادة التربية الفنية بحياة الطلاب و المهن المستقبلية) عند مستوى (موافق) بوزن 
د/ بثينة عبد الله الملا

نسبي (T + , ع) بما يعد مؤشرًا مرتفعًا لدور مواقع التو اصل الاجتماعي في تنمية ارتباط مادة التربية الفنية بحياة الطلاب و المهن المستقبلية. - جاءت ثناث مؤشر ات بـالمحور الثالث لاتجاهـات طلاب المرحلة الثانويـة نحو التربية الفنية (ارتباط مـادة التربيـة الفنيـة بحياة الطلاب و المهن المستقبلية) عند

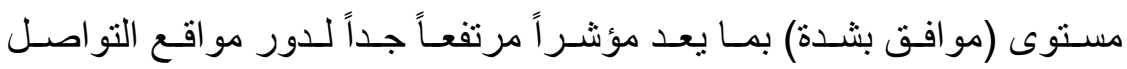

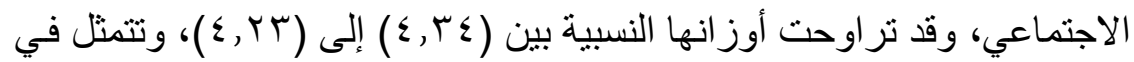
(أنشعر برغبة في الاستفادة من خامات البيئة في انتاج أعمال فنية، أشتعر برغبة

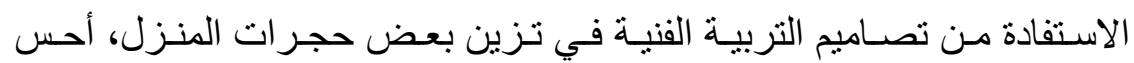
برغبة في تنفيذ بعض المجسمات اليدوية لتزين المنازل و الثوارع). - جاءت معظم مؤشر ات المحور الثالث لاتجاهـات طلاب المرحلة الثانويـة نحو التربية الفنية (ارتباط مـادة التربيـة الفنيـة بحياة الطلاب و المهن المستقبلية) عند مستوى (موافق) بما يعد مؤشرًا مرتفعًا لدور مواقع التواصل الاجتمـاعي، وقد

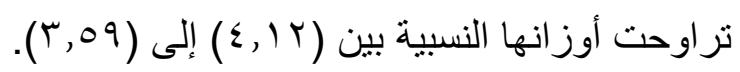

ويمكن أن يرجع ذلك إلى الربط الذي تحدثه مو اقع التواصل الاجتمـاعي بين

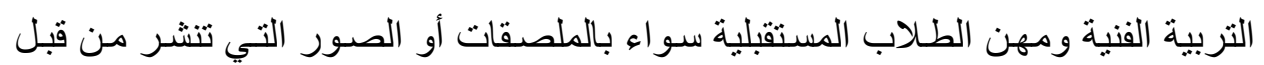
الطلاب او باستير اد أعمال فنية لفنانين و إعادة نشر ها على مواقع التو اصل من تعبير فني وزخرفة اليدوية والرسم على القماش أو النحت على الخشب ممـا يشـعر الطالب برغبة فئة

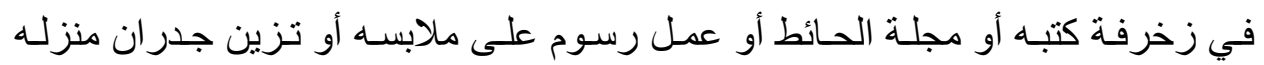
و الثنار ع أو التخصص في أحد مهن التربية الفنية. نتائج مقيـاس اتجـاه طلاب المرحلة الثانويـة نحو التربيـة الفنيـة في ضوع دور مواقع التواصل الاجتماعي 
دور مواقع التواصل الاجتماعي في تحقيق أهداف التربية الفنية والاتجاهات نحوها لاى طلاب المرحلة الثانوية

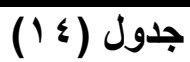

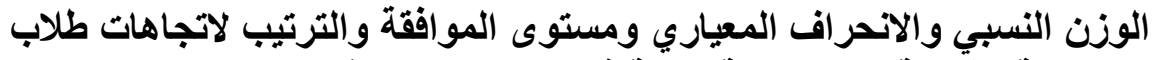

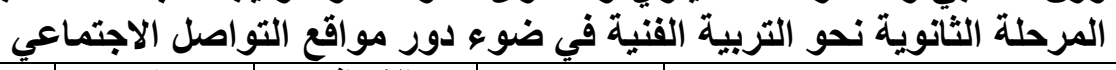

\begin{tabular}{|c|c|c|c|c|}
\hline 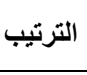 & مستوي & ال المعياري & الوزن النسبي & 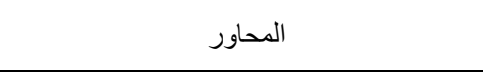 \\
\hline 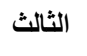 & 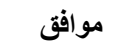 & זיו, & $r, 9 \wedge$ & المحور الأول: أهمية التربية الفنية \\
\hline 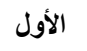 & موافق بشدة & $\cdot, 79$ & $\varepsilon, r_{0}$ & المحور الثاني: تذوق محتوى مادة التربية الفنية \\
\hline \multirow[t]{2}{*}{ الثاني } & 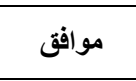 & $\cdot, \mathrm{VT}$ & $\varepsilon,+7$ & المحور الثالث: ارتباط مادة التربية الفنية بحياة \\
\hline & 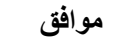 & זיד & $\varepsilon, 1$. & اجمالي مقياس الاتجاه \\
\hline
\end{tabular}

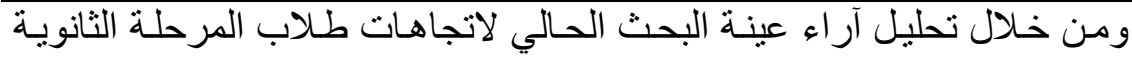

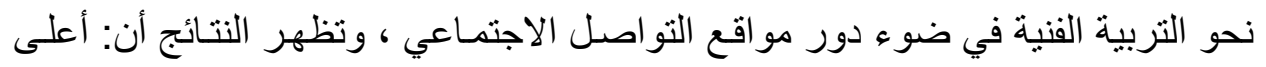

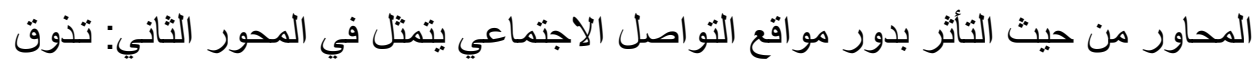

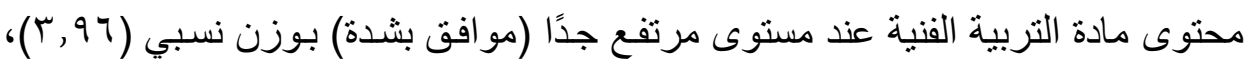
و هذا يتفق مع نفس الدور الذي تؤديه من تحقيق أهداف التربيـة الفنية ويتمثل في الهدف الثالث: التذوق الفني، يليه المحور الثالث: ارتباط مادة التربية الفنية بحياة الطلاب والمهن

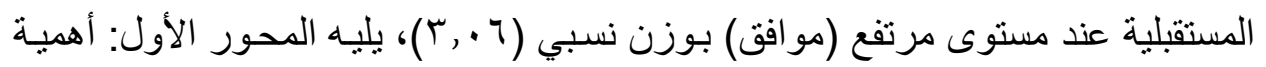
التربية الفنية عند مستوى مرتفع (موافق) بوزن نسبي (ب,9^)؛ وتتفق هذه النتائج مـع العديد من الدر اسات كدر اسـة محمود (9 ( ـ ب) التي توصل إلى فاعلية استخدام المدخل التكنولوجي من خلال الرحلات المعرفية عبر الويب "Web Quests" في تدريس

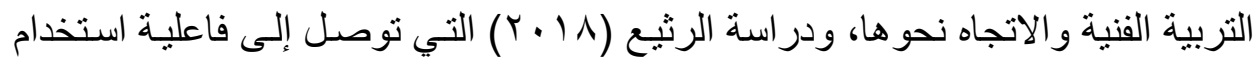
المدخل التكنولوجي و الدر اسي التقليدي من خلال التعلم المدمج في تنمية الاتجاه نحو مـادة

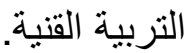


دا بثينة عبد الله الملا

نتائج السؤال الرابع ومناقشتها وتفسير ها: نص السؤال الرابع: ما مدى اختلاف استجابات عينة البحث في اتجاهـاتهم نحو

دور مواقع التو اصـل الاجتمـاعي في تحقيق أهداف التربيـة الفنيـة في ضـوء متغيـرات (النوع، الصف، مواقع التواصل الأكثر استخداماً)؟

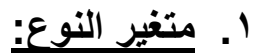

ولمعرفة مدى وجود فروق بين استجابات عينة البحث نحو دور مواقع التواصل الاجتماعي في تحقيق أهداف التربية الفنية تعزي إلى متغير النوع، وللإجابة على السؤال تم حساب قيمة اختبار(ت) للفروق بين متوسطي درجات عينة البحث، وفيما يلي ملخص للنتائج:

\section{جدول (10)}

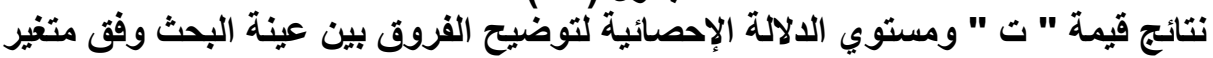

(النوع) على استبانة دور مواقع التواصل الاجتماعي في تحقيق أهداف التربية الفنية

\begin{tabular}{|c|c|c|c|c|c|c|c|c|c|}
\hline الدلالة الاحصائية & ت & الحرجات & فلمروقات & الخعياري & الانحر اف & المتوسط & العدد & النوع & الأداة \\
\hline • & \multirow{2}{*}{$1, Y v V$} & \multirow{2}{*}{$1 \leqslant 4$} & \multirow{2}{*}{., 1} & $\cdot, \cdot v \varepsilon$ & ., orr & $r, v V$ & or & ذكور & \multirow{2}{*}{ استبانة تحقيق } \\
\hline غير دالة إحصائيًا & & & &., .01 &.,$\leqslant १ \wedge$ & $r, \wedge \wedge$ & 94 & إناث & \\
\hline
\end{tabular}

باستقراء بيانات الجدول السابق يتضح أنه لا يوجد فرق دال إحصائًا عند

مستوى (0., •) بين متوسطي استجابات عينة البحث حول دور مواقع التواصل

الاجتماعي في تحقيق أهداف التربية الفنية تعزي إلى متغير النوع؛ حيث بلغت قيمة (ت)

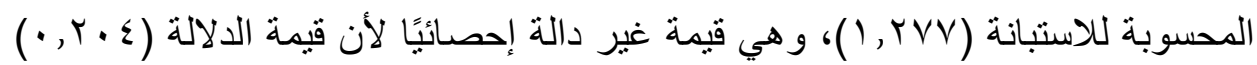
أكبر من مستوى الدلالة (0., •)، مما يشير إلى أنه لا يوجد فرق دال إحصائياً بين الطلاب الذكور والإناث، ويمكن أن يرجع ذلك إلى أن الاقبال على استخدام مواقع إنى التواصل الاجتماعي للنوعين الذكور والاناث دون تميز لتوافر أدوات التواصل و الاتصال بهذه المواقع ودعمها للمستندات والصور والفيديو مما يحفز الطلاب على الطى استخدامها كوسيلة لتحقيق أهداف التربية الفنية. 
ولمعرفة مدى وجود فروق بين عينة البحث حول دور مواقع التواصل الاجتماعي في تحقيق أهداف التربية الفنية تعزي إلى متغير الصف الدراسي، تم استخدام أسلوب تحليل التباين الأحادي وتتضح النتائج من الجدول التالي:

$$
\text { جدول (17) }
$$

المتوسطات والانحرافات المعيارية بين عينة البحث وفق متغير (الصف الدراسي) على الصى

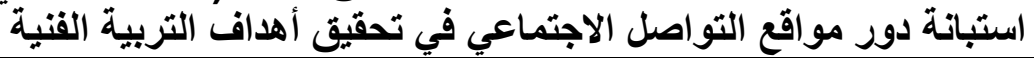

\begin{tabular}{|c|c|c|c|c|c|}
\hline الخطأ المعياري & الانحراف المعياري & المتوسط & 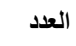 & الصف الدراسي & الاداة \\
\hline., $.0 \mathrm{~V}$ & .,OH & $r, \wedge \circ 0$ & $\wedge q$ & العاثشر & \multirow{4}{*}{ تحقيق الأهداف } \\
\hline.,$\cdot V Y$ & $\cdot, r \leq \leq$ & $r, q 1 r$ & rr & الحادي عثر & \\
\hline., $.9 Y$ &., 001 & $r, \vee \wedge 1$ & $r y$ & الثاني عثر & \\
\hline$\cdot, \cdot \leq Y$ &., $01 Y$ & $\Gamma, \wedge \leq \uparrow$ & $1 \leq 1$ & اجمالي & \\
\hline
\end{tabular}

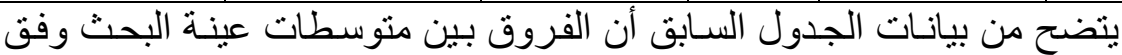

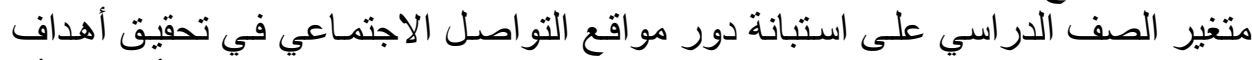

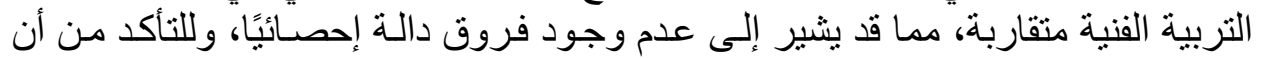

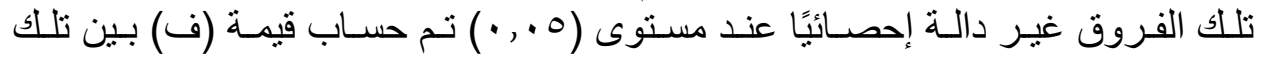

جدول (iv)

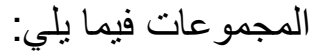

نتائج تحليل التباين لتوضيح الفروق بين عينة البحث وفق متغير (الصف الدراسي) على استبانة دور مواقع التواصل الاجتماعي في تحقيق أهداف التربئية التربية القنية

\begin{tabular}{|c|c|c|c|c|c|c|}
\hline الإحصائية الالية & قيمة (ف) & (التباينات) & الحرية & المربعوات & مصدر التباين & المحاور \\
\hline., 7.7 & \multirow{3}{*}{$\cdot, 0 \cdot r$} & ., & $r$ & . & المجموعات & \multirow{3}{*}{ الأحقيق } \\
\hline \multirow{2}{*}{ غير دالة } & & • & $1 \leqslant 0$ & $r \wedge, r q r$ & المجموعات & \\
\hline & & & $1 \leqslant V$ & $r \wedge, \diamond r \wedge$ & المجموع & \\
\hline
\end{tabular}

باستقراء بيانات الجدول السابق يتضح أنه لا يوجد فرق دال إحصائيًا عند مستوى (0., •) بين متوسطي استجابات عينة البحث حول دور مواقع التواصل الاجتماعي في تحقيق أهداف التربية الفنية تعزي إلى متغير الصف الدراسي؛ حيث بلغت قيمة (ف) المحسوبة للاستبانة (r • 0 )، و هي قيمة غير دالة إحصائياً لأن قيمة الدلالة

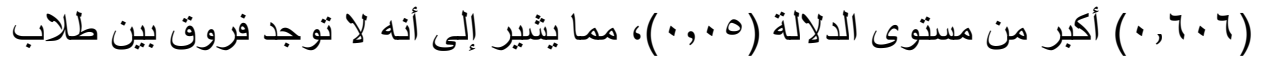


د/ بثينة عبد الله الملا

الصف العاثر و الحادي عشر والثاني عشر، ويمكن أن برجع ذلك إلى أن بداية استخدام

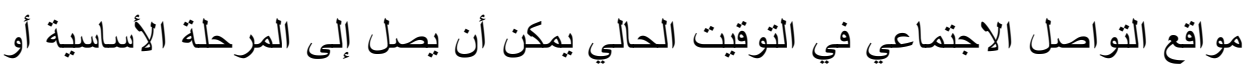

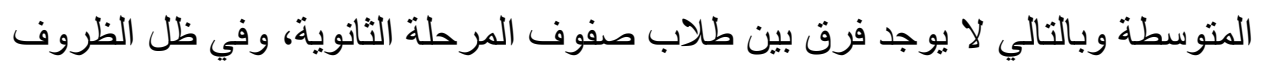

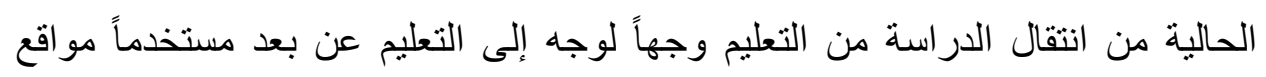
التو اصل الاجتماعي في ذلك.

\section{r. مواقع التواصل الأكثر استخدامًا:}

ولمعرفة مدى وجود فروق بين عينة البحث حول دور مواقع التواصل الاجتماعي في تحقيق أهداف التربية الفنية تعزي إلى متغير مواقع التواصل الأكثر

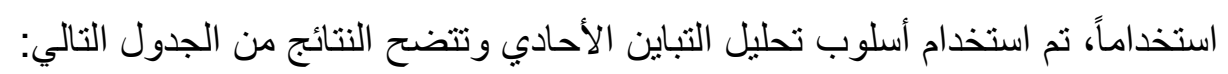

جدول (11)

المتوسطات والانحر افات المعيارية بين عينة البحث وفق متغير (مواقع التواصل الأكثر استخداماً) على التى

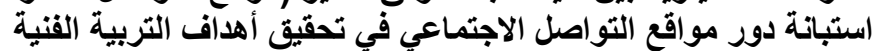

\begin{tabular}{|c|c|c|c|c|c|}
\hline الخطأ المعياري & الاتحراف المعياري & المتوسط & العدد & الأكثر استخداماً التواصل & الاداة \\
\hline$\cdot, 9$. &., $00 \mathrm{~V}$ & 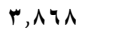 & rA & تويتر & \multirow{4}{*}{ استبانة تحقيق } \\
\hline$\cdot, 1 \cdot \varepsilon$ & ודי, י & $r, \vee \wedge q$ & rv & واتس أب & \\
\hline$\cdot, \cdot \leq 9$ & $\cdot, \leqslant 11$ & $r, \wedge \uparrow r$ & $v r$ & انستجرام & \\
\hline$\cdot, \cdot \leq Y$ &., $01 Y$ & $r, \Lambda \leq T$ & $1 \leqslant 1$ & اجمالي & \\
\hline
\end{tabular}

يتضح من بيانـات الجدول السـابق أن الفروق بين متوسطات عينة البحث وفق

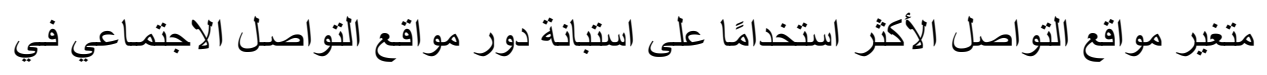
تحقيق أهداف التربية الفنية، مما قد يثير إلى عدم وجود فروق دالة إحصائيًا، وللتأكد من الن الني

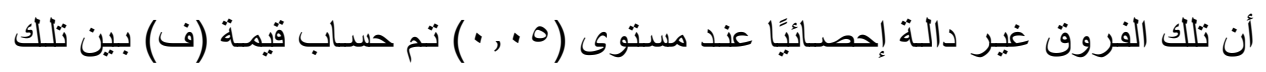

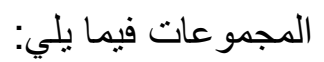


دور مواقع التو اصل الاجتماعي في تحقيق أهاف التربية الفنية والاتجاهات نحوها لدى طلاب المرحلة الثانوية

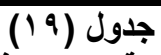

نتائج تحليل التباين لتوضيح الفروق بين عينة البحث وفئ متفير (مواقع التواصل الأكثر استخداماً)

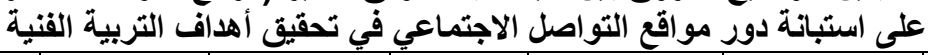

\begin{tabular}{|c|c|c|c|c|c|c|}
\hline الإحصائية & قيمة (ف) & (المربعات & الحرجية & المربعوع & مصدر التباين & الاداة \\
\hline$\cdot, v \leqslant$. & \multirow{3}{*}{$\cdot, r \cdot r$} & $\cdot, \wedge$. & $r$ & $\cdot, 14$ & المجموعات & \multirow{3}{*}{ لأحدقيق } \\
\hline \multirow{2}{*}{ غير دالةً } & & - & $1 \leqslant 0$ & $r \Lambda, r \neg \Lambda$ & 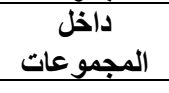 & \\
\hline & & & $1 \leqslant V$ & $\Gamma_{\Lambda, O Y \Lambda}$ & المجموع & \\
\hline
\end{tabular}

باستقراء بيانات الجدول السابق يتضح أنه لا يوجد فرق دال إحصائًاً عند مستوى (0., •) بين منوسطي استجابات عينة البحث حول دور مواقع التواصل الاجتماعي في تحقيق أهداف التربية الفنية تعزي إلى متغير مواقع التواصل الأكثر لترابن

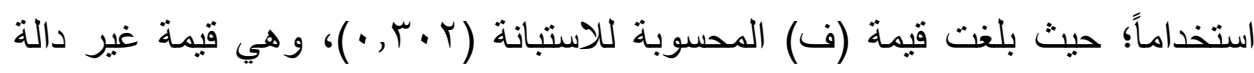

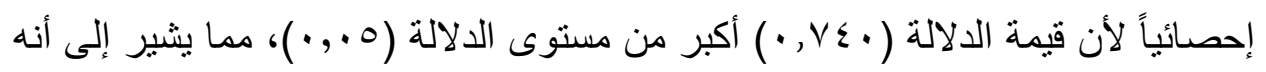
لا توجد فروق بين نوع وسيلة التو اصل الأكثر استخداماً (تويتر ، واتس أب، انستجرام)، ويمكن أن يرجع ذلك إلى أن الثلاثة مواقع تتوافر بهم نفس الأدوات وهي الارسال و الاستقبال والمشاركة للمستندات والصور و الفيديوها وان كان تويتر أقلهم في حجم

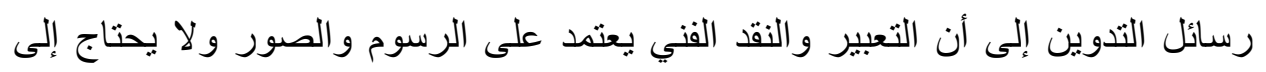
كتابة كلمات كثيرة لتحقيق أهداف التربية الفنية. ومن خـلال تحليل آراء عينـة البحث الحسالي من طلاب المرحلـة الثانويـة حول

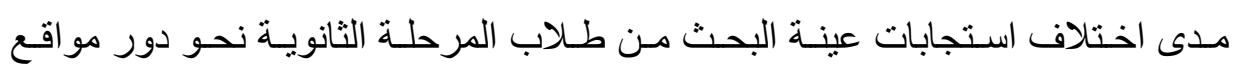

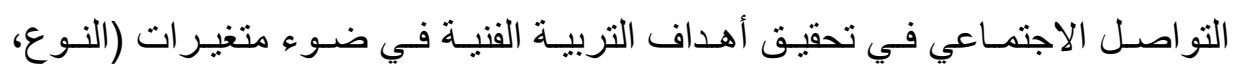
الصف، مواقع التواصـل الأكثر استخداماً)، أتضـح أنـه لا توجد فروق دالـة إحصــائياً

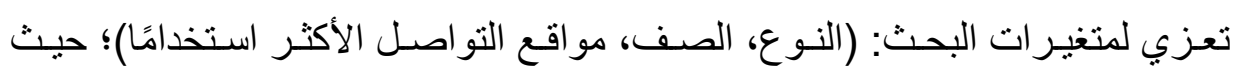

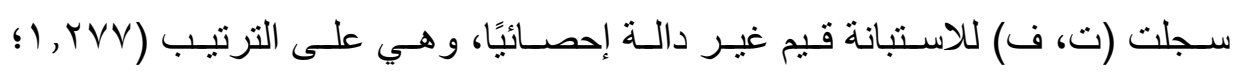
.$(\cdot, r \cdot r \leq \cdot, 0, r$

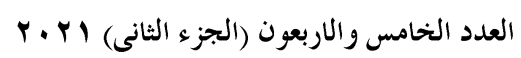

(530)

مجلة كلية التربية- جامعة عين شمس 
د/ بثينة عبد الله الملا

نتائج السؤال الخامس ومناقشتها وتفسير ها:

نص السؤال الخامس: ما مدى اختلاف استجابات عينـة البحث حول اتجاهـاتهم

نحو التربيـة الفنيـة في ضوء دور مواقع التواصل الاجتمـاعي تعزي لمتغيرات (النوع، الصف، مواقع التواصل الأكثر استخداماً)؟

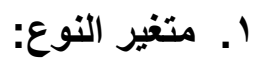

ولمعرفة مدى وجود فروق بين استجابات عينة البحث في اتجاهاتهم نحو التربية

الفنية في ضوء دور مواقع التواصل الاجتماعي تعزي إلى متغير النوع، وللإجابة على السؤال تم حساب قيمة اختبار(ت) للفروق بين متوسطي درجات عينة البحث، وفيما يلي لئي

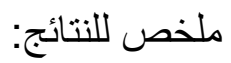

\section{جدول (10)}

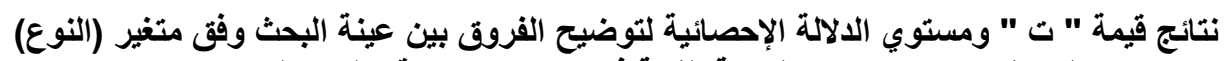

\begin{tabular}{|c|c|c|c|c|c|c|c|c|c|}
\hline الدلالة الاحصائية & ت & درجات & المنوسطات & المعياري & المعياري & المتوسط & |العدد & النوع & الأداة \\
\hline$\cdot, q \cdot v$ & \multirow{2}{*}{$\cdot, 11 V$} & \multirow{2}{*}{$1 \leqslant 4$} & \multirow{2}{*}{$\cdot, \cdot 1 \mathrm{TV}$} & $\cdot, \cdot v \varepsilon$ & .,OrV & $\varepsilon, .9$ & Or & ذكور & \multirow{2}{*}{ مقياس الاتجاه } \\
\hline غير دالة إحصائياً & & & &., .99 & - & $\varepsilon, 1$. & 97 & إناث & \\
\hline
\end{tabular}

باستقراء بيانات الجدول السابق يتضح أنه لا يوجد فرق دال إحصائيًا عند

مستوى (0 • , • ) بين متوسطي استجابات عينة البحث حول اتجاهاتهم نحو التربية الفنية

في ضوء دور مواقع التواصل الاجتماعي تعزي إلى متغير النوع؛ حيث بلغت قيمة (ت) المحسوبة لمقياس الاتجاه (IV I I • )، وهي قيمة غير دالة إحصائياً؛ لأن قيمة الدلالة

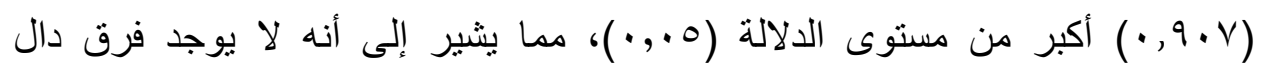
إحصائياً بين الطلاب الذكور والإناث، ويمكن أن يرجع ذلك إلى أن اتجاه النوعين (الذكور والاناث) نحو استخدام مو اقع التواصل الاجتماعي يرجع إلى التحول الدراسي للتعليم من وجهاً لوجه في الفصل الدراسي إلى التعليم عبر شبكة الانترنت مستخدمًا 
دور مواقع التواصل الاجتماعي في تحقيق أهداف التربية الفنية والاتجاهات نحوها لاى طلاب المرحلة الثانوية

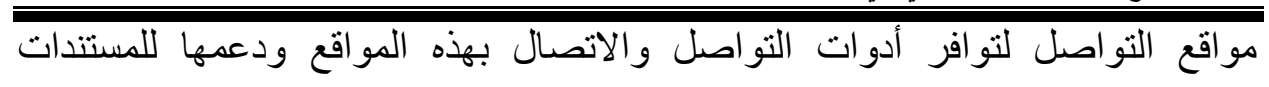
والصور و الفيديو مما يحفز الطلاب على استخدامها بغض النظر عن نوعهم.

\section{r. ب متغير الصف الدراسي:}

ولمعرفة ددى وجود فروق بين عينة البحث حول اتجاهاتهم نحو التربية الفنية

في ضوء دور مواقع التو اصل الاجتماعي تعزي إلى متغير الصف الدراسي، نم استخدام أسلوب تحليل التباين الأحادي وتتضح النتائج من الجدول التالي: جدول (17)

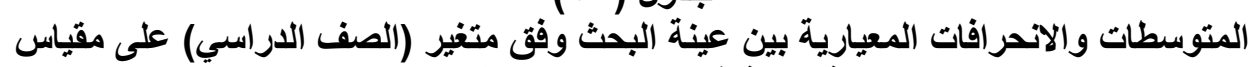

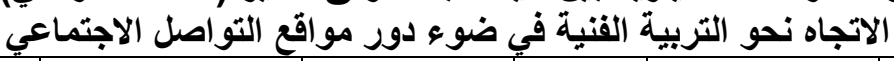

\begin{tabular}{|c|c|c|c|c|c|}
\hline الخطأ المعياري & الانـمراف & المتوسط & العدد & الصف الدراسي & الاداة \\
\hline$\cdot, \cdot v r$ & $\cdot, 7 \wedge \varepsilon$ & $\varepsilon, \cdot V r$ & $\wedge 9$ & العاثر & \multirow{4}{*}{ الاتجاه } \\
\hline., .91 & $\cdot, \leqslant \vee 1$ & $\varepsilon, \mid r \mu$ & $r r$ & الحادي عشر & \\
\hline$\cdot, .9 \leq$ & $\cdot, \Delta \wedge \mu$ & $\varepsilon, 1 p q$ & q & الثاني عشر & \\
\hline., $.0 r$ & $\cdot, 7 r \wedge$ & $\varepsilon, .9 \wedge$ & $1 \leqslant 1$ & اجمالي & \\
\hline
\end{tabular}

يتضح من بيانـات الجدول السـابق أن الفروق بين متوسطات عينـة البحث وفق

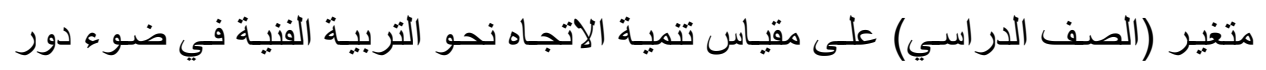
مو اقع التواصل الاجتماعي متقاربة، مما قد يشير إلى عدم وجود فروق دالة إحصـائًا،

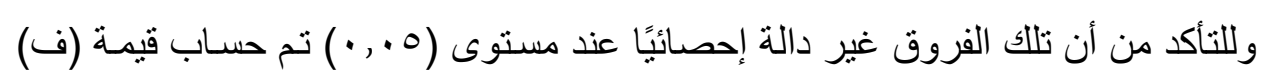
بين تللك المجمو عات فيما يلي: 


$$
\text { جدول (iv) }
$$

نتائج تحليل التباين لتوضيح الفروق بين عينة البحث وفق متغير (الصف الدراسي) على مقياس الاتجاه نحو التربية الفنية في ضوء دور مواقع التواصل الاجتماعي

\begin{tabular}{|c|c|c|c|c|c|c|}
\hline الإحصائية & قيمة (ف) & (التباينات) & الدرجية & مجموع المربعات & مصدر التباين & المحاور \\
\hline 促, & \multirow{3}{*}{$\cdot, 1 \wedge 0$} &.,$\cdot \vee \leqslant$ & $r$ &., $1 \leqslant 1$ & المحميوعات & \multirow{3}{*}{ مقياس } \\
\hline \multirow{2}{*}{ غير دالة } & & \& & $1 \leqslant 0$ & OV, QAY & المجموعات & \\
\hline & & & $1 \leqslant V$ & $\Delta \wedge, 1$ rq & المجموع & \\
\hline
\end{tabular}

باستقراء بيانات الجدول السابق يتضح أنه لا يوجد فرق دال إحصائيًا عند مستوى (0. . • ) بين منوسطي استجابات عينة البحث حول اتجاهاتهم نحو التربية الفنية في ضوء دور مواقع التواصل الاجتماعي تعزي إلى متغير الصف الدراسي؛ حيث بلغت قيمة (ف) المحسوبة لمقياس الاتجاه (10 ( ) •))، وهي قيمة غير دالة إحصائياً؛ لأن قيمة

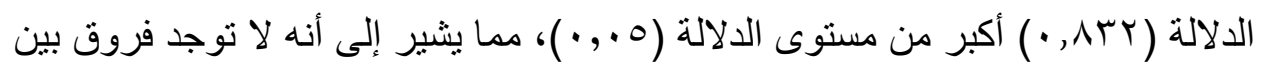
طلاب الصف العاثر والحادي عشر والثاني عشر، ويمكن أن يرجع ذلك إلى أن بداية

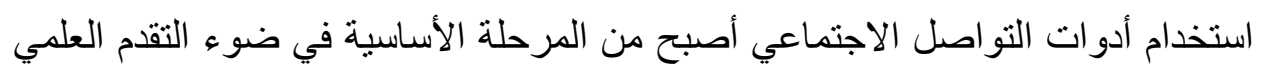
و التكنولوجي وفي ظل الظروف الحالية من انتقال الدراسة من التعليم وجهاً لوجه إلى مئ التعليم عن بعد مستخدماً مو اقع التواصل الاجتماعي في ذلك.

r. مواقع التواصل الأكثر استخدامًا:

ولمعرفة مدى وجود فروق بين عينة البحث حول اتجاهاتهم نحو التربية الفنية في ضوء دور مواقع التواصل الاجتماعي تعزي إلى متغير مواقع التواصل الأكثر استخدامًا، تم استخدام أسلوب تحليل التباين الأحادي وتتضح النتائج من الجدول التالي: 
دور مواقع التواصل الاجتماعي في تحقيق أهداف التربية الفنية والاتجاهات نحوها لدى طلاب المرحلة الثانوية

$$
\text { جدول (11) }
$$

المتوسطات والانحر افات المعيارية بين عينة البحث وفئ متغير (مواقع التواصل الأكثر

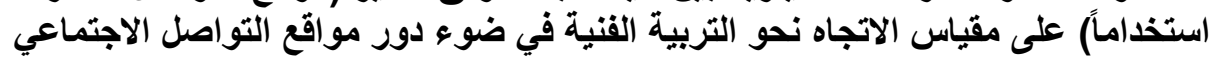

\begin{tabular}{|c|c|c|c|c|c|}
\hline الخطأ المعياري & الانحراف المعياري & المتوسط & العدد & الأكثر استخد التواصل & الاداة \\
\hline$\cdot, ., 14$ & 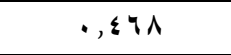 & $\varepsilon, Y \leqslant$ & $r \Lambda$ & تويتر & \multirow{4}{*}{ مقياس الاتجاه } \\
\hline., $1 Y T$ & $\cdot, A .7$ & $r, 9 \vee \wedge$ & $r v$ & واتس أب & \\
\hline $0 ., 79$ & - & $\varepsilon, \cdot \wedge \theta$ & $V_{r}$ & انستجرام & \\
\hline., $.0 Y$ & - & $\varepsilon, .91$ & $1 \leqslant 1$ & اجمالي & \\
\hline
\end{tabular}

يتضح من بيانـات الجدول السـابق أن الفروق بين متوسطات عينـة البحث وفق اهُ

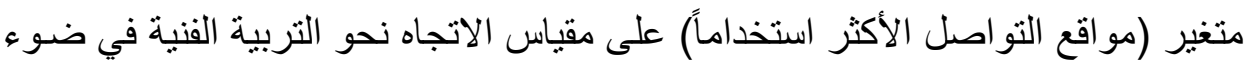

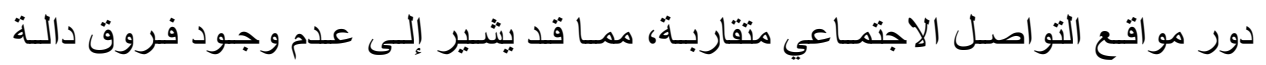

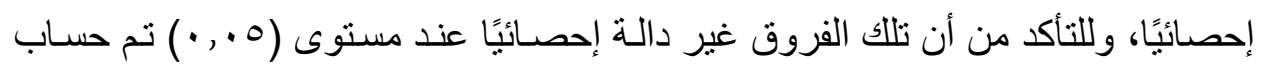
قيمة (ف) بين تلك المجمو عات فيما يلي:

جدول (19) (19)

نتائج تحليل التباين لتوضيح الفروق بين عينة البحثث وفق متئير (مواقع التئ التواصل الأكثر

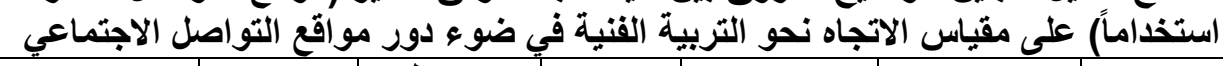

\begin{tabular}{|c|c|c|c|c|c|c|}
\hline الإحصائية & قيمة (ف) & (التباينات) & الحرية & المربعوت & مصدر التباين & الاداة \\
\hline., 191 & \multirow{3}{*}{$1,7 \times 0$} & 19, & r & WוTוT & المجموعات & \multirow{3}{*}{ مقاتجاه } \\
\hline \multirow{2}{*}{ غير دالة } & & • & $1 \leqslant 0$ & $\Delta \checkmark, \wedge, V$ & المجموعات & \\
\hline & & & $1 \leqslant v$ & $0 \wedge, 1 Y q$ & المجموع & \\
\hline
\end{tabular}

باستقراء بيانات الجدول السابق يتضح أنه لا يوجد فرق دال إحصائيا عند

مستوى (0. . • ) بين متوسطي استجابات عينة البحث حول اتجاهاتهم نحو التربية الفنية في ضوء دور مواقع التواصل الاجتماعي تعزي إلى متغير مواقع التواصل الأكثر

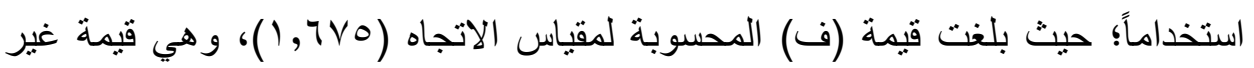
دالة إحصائياً؛ لأن قيمة الدلالة (19 (1, •) أكبر من مستوى الدلالة (0. . . •)، مما بشير إلى أنه لا نوجد فروق دالة احصائيًا بين نوع وسيلة التواصل الأكثر استخدامًا (تويتر ، 
واتس أب، انستجرام)، ويمكن أن يرجع ذلك إلى أن الثلاثة مواقع تتوافر بهم نفس

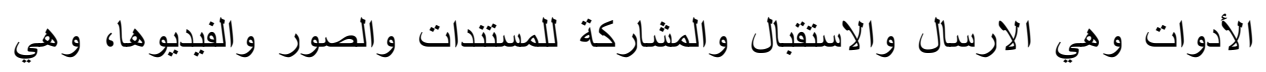
مواقع للاتصال والتواصل في التعليم عن بعد عبر مواقع التو اصل الاجتماعية.

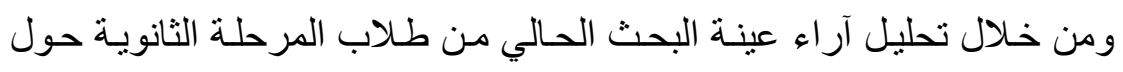

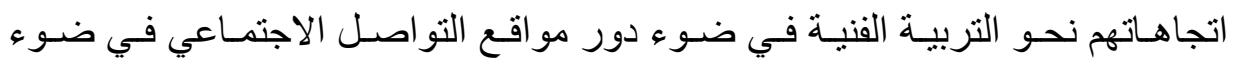
متغيرات (النوع، الصف، مواقع التواصل الأكثر استخداماً)، أتضح أنه لا توجد فروق

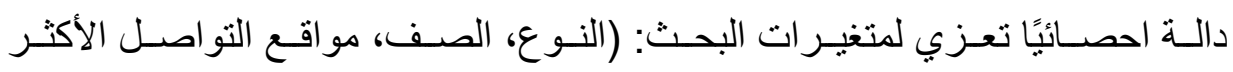
استخداماً)؛ حيث سـلت (ت، ف) للاستبانة ومقيـاس الاتجـاه قيم غير دالـة إحصـائياً،

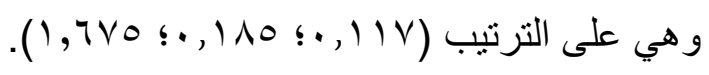

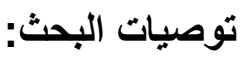

في ضـوء نتائج البحث يمكن اقتر اح مجمو عـة من التوصيات التي يمكن من خلالها تدعيم دور مو اقع التواصل الاجتمـاعي في تحقيق أهداف التربية الفنية وتكوين اتجاهات ايجابية نحوهـا لدى طلاب المرحلة الثانويـة، ومنها توصيات خاصـة بالقائمين

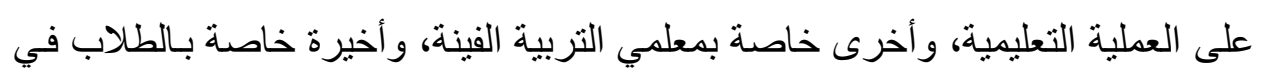

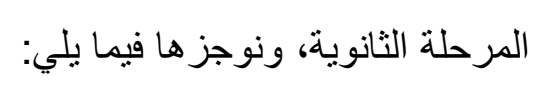

القائمين على العملية التعليمية، ويتطلب منهم الاهتمام بدور مواقيم اقع التو اصل الاجتمـاعي

$$
\text { في تحقيق أهداف التربية الفنية في بعض الجوانب ومنها: }
$$

- - تقنين استخدام مواقع التواصل الاجتماعي كمنصة تعليمية في العملية التعليمية. - - اختيار نوع واحد من مواقع التو اصل الاجتمـاعي لاستخدامه كمنصـة في تعليم وتعلم التربية الفنية.

- وضع ضو ابط للحفاظ على للتعامل على مو اقع التواصل الاجتماعي للحفاظ على الهوية والانتماء الوطني كمنصة تعليمية في تعليم وتعلم التربية الفنية. 
دور مواقع التواصل الاجتماعي في تحقيق أهداف التربية الفنية والاتجاهات نحوها لاى طلاب المرحلة الثانوية

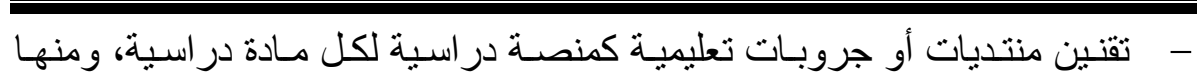

التربية الفنية.

- - وضـع مسؤولين على هذه المنتـيات لإضـافة الطـلاب و المعلمين و المـوجهين عليها للمساهمة في توجيه و إرشاد الطلاب لزيادة الإنتاج الفني للطلاب. - - وضع بعض المشرفين على المنتديات لتسويق الإنتاج الفني للطلاب عبر مواقع التو اصل الاجتماعي.

- - تحديد المجالات الفنية المناسبة لميولي الطلاب في التعبير الفني عبر منصـة مو اقع التواصل الاجتماعي. - - توفير مجموعة من خبر اء الفن لتقنين فسلفة الفن عند الطلاب، ودعمهم في التدريب على مقومات العمل الفني عبر مواقع التواصل الاجتماعي. - - توفير دورات تدريبية للمعلمين و الموجهين للتدريب على كيفية إدارة التعلم عبر مواقع التواصل الاجتماعي لتقنين النقد الفني أثناء تحقيق أهداف التربية الفنية. - - تدريب الطلاب على كيفية التفاعل والالتزام والحضور التزامني عبر مواقع

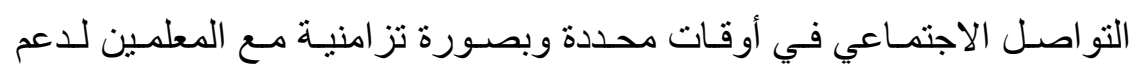
التواصل الفني وتتمية اتجاهاتهم نحو المادة.

- - تعميم استخدام مواقع التواصل الاجنمـاعي في التعليم عن بعد لتحقيق أهداف التربية الفنية على جميع مر احل التعليم. معلمي المرحلة الثانوية، ويتطلب منهم ما يلي:

- - رفع مستوى مهار اتهم الرقمية في استخدام و إدارة مواقع التواصل الاجتمـاعي في تحقيق أهداف التربية الفنية. - - تكوين علاقات طيبة مع طلاب المرحلة الثانوية عبر مواقع التواصل الاجتماعي لتتمية اتجاهاتهم نحو المادة. 
- - تشجيع الطلاب على المشاركة الفنية والتذوق و النقد الفني و التو اصل على مواقع

$$
\text { التواصل الاجتماعي. }
$$

- - تقديم التغذية الراجعة والتعزيز المستمر للطلاب بشكل مباثـر أثنـاء التعلم عبر

$$
\text { مواقع التو اصل الاجتماعي. }
$$

- عقد لقاءات دورية مع الطلاب للتعرف على المشكلات التي تواجهمح أثناء التعلم

$$
\text { عبر مواقع التو اصل الاجتماعي. }
$$

- - بـث الروح الفنية في نفوس الطـلاب ومسـاعدتهم على الثـعور بأهميـة التربيـة الفنية، وتذوق محتو اها.

- ربط حياة الطلاب بمادة التربية الفنية و المهن المستقلية الخاصة بها. طلاب المرحلة الثانوية، ويتطلب منهم ما يلي:

- الالتزام بقو اعد وقو انين مواقع التواصل الاجتماعي لتحقيق أهداف التربية الفنية. - أهمية الالتزام بالقيم الأخلاقية في العمل فني على مواقع التو اصل الاجتماعي. - - التعـاون المثــر و التفاعل الدائم مـع معلم التربيـة الفنية أثنـاء أداء الإنتاج الفنـي على مو اقع التو اصل الاجتماعي. - - التعاون المثمر مع المعلم عبر مواقع التو اصل الاجتمـاعي لدعم وتوجيـه التذوق الفني لديهم لتنمية اتجاهاتهم نحو التربية الفنية. - - الاهتمام بتاريخ الفن وتعدد الثقافات الفنيـة ودعم النقد البنـاء لإتثراء الفكر الفني من خلالها. - - التواصل الفني بينهم وبين زملائهم عبر منتديات مو اقع التواصل الاجتمـاعي لإنشاء المعارض الفنية و الصفحات التشكيلية. - - المشـاركة بالأعمـال الفنيـة التي تربط بين الواقع الحيـتي لديهم و المهـن الفنيـة المستقبلية لهم. 
في ضوء نتائج البحث الحالي يمكن تقديم مجمو عة من المقترحات فيما يلي: - - دور مو اقع التو اصل الاجتماعي في تحقيق أهداف التربية الفنيـة وميولهم نحوهـا للدى طلاب المرحلة المتوسطة. - - دور المنصات الرقمية المستخدمة في التعليم عن بعد في تحقيق أهداف التربيـة و الاتجاهات نحو ها لدى طلاب المرحلة الثانوية. - - دور مواقع التواصـل الاجتمـاعي في التحصيل المهـاري للتربيـة الفنيـة وتتميـة مهار ات التعلم الذاتي لاى طلاب المرحلة الثانوية. - - دور مواقع التواصل الاجتمـاعي في تنميـة التعبير و التحليل و النقد الفنـي لدى طلاب المرحلة الثانوية. - - تقويم معايير الجودة الثناملة لمواقع التواصل الاجتمـاعي المستخدمة في التعليم عن بعد لدى طلاب المرحلة الثانويـة من وجهة نظر معلمي وموجهي التربية الفنية. - - الكفايـات التعليميـة و المهنيـة لطلاب المرحلة الثنانويـة لاستخدام مو اقع التواصل الاجتماعي في تحقيق أهداف التربية الفنية. 


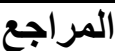

أولًا: المراجع العربية

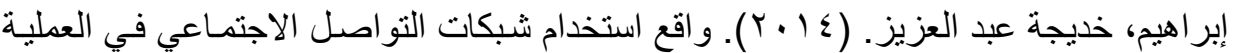

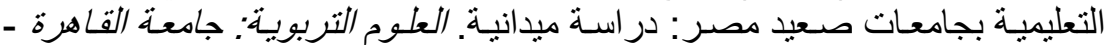

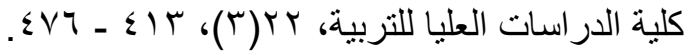

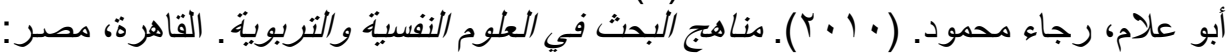

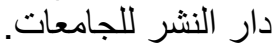

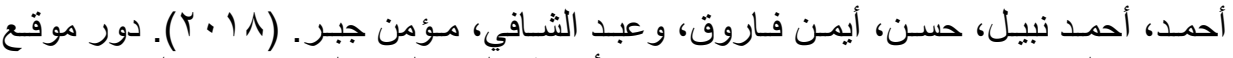

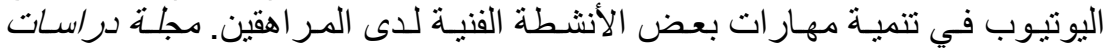

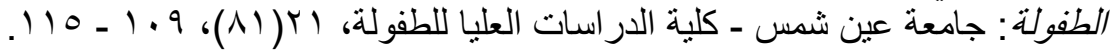

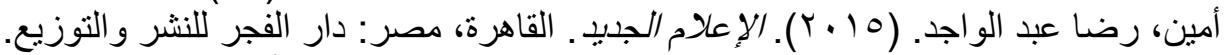

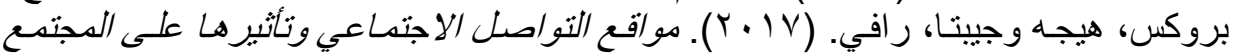

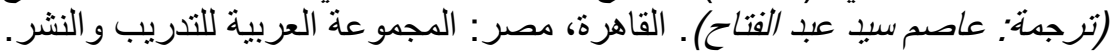

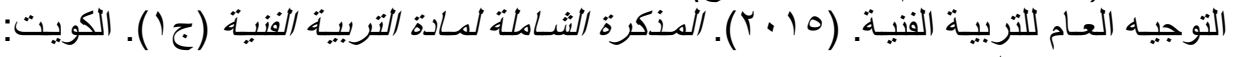

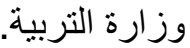

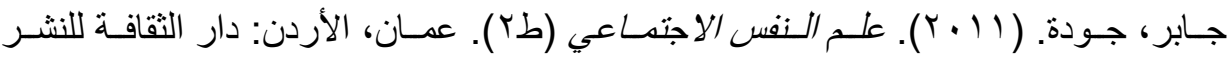

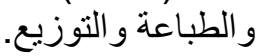

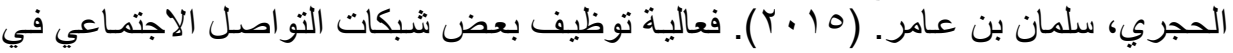

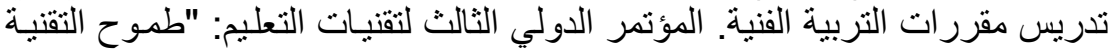

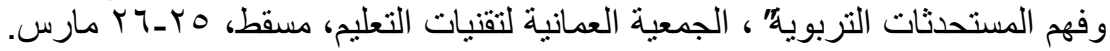

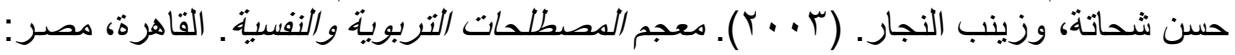
الدار المصرية اللبنانية.

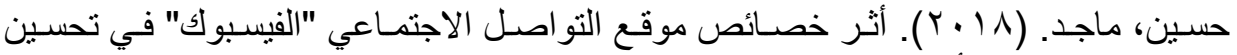

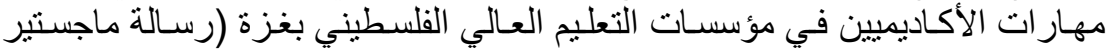

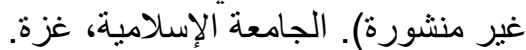

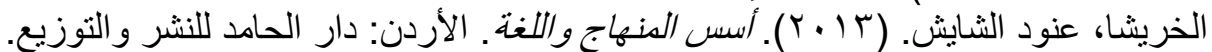

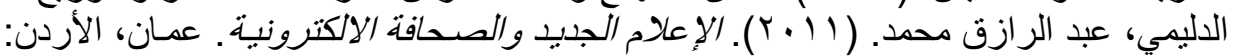

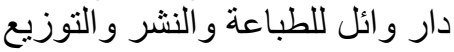

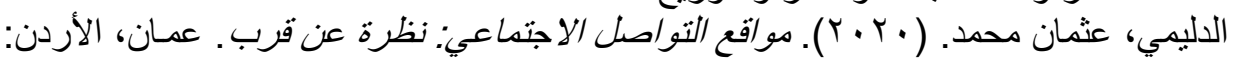

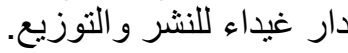

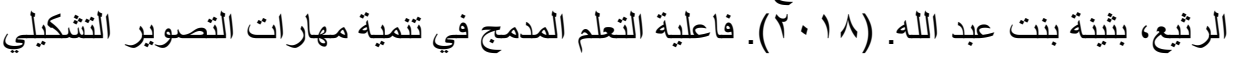

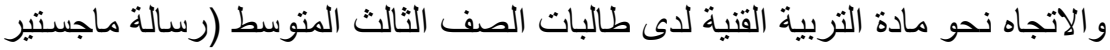

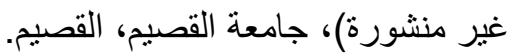

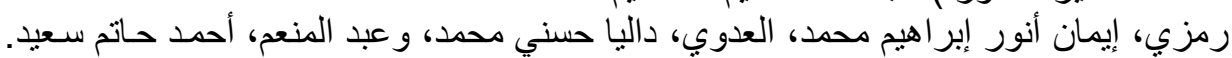

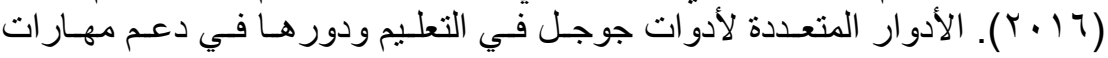


دور مواقع التواصل الاجتماعي في تحقيق أهداف التربية الفنية والاتجاهات نحوها لدى طلاب المرحلة الثانوية

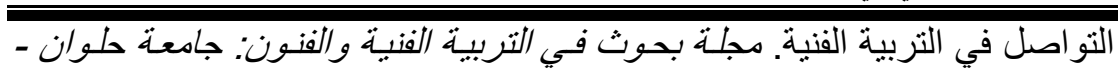

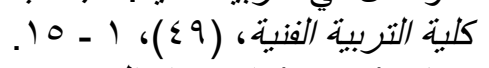

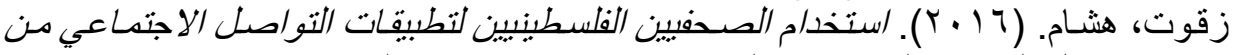

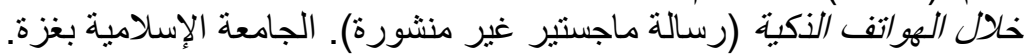

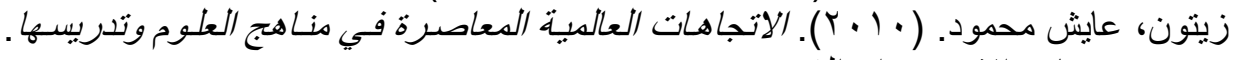

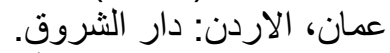

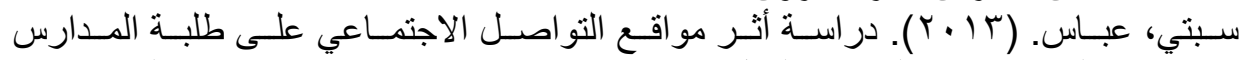

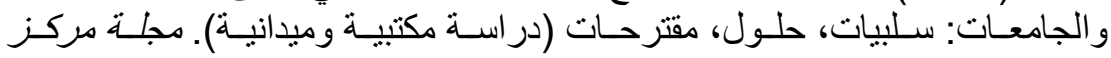

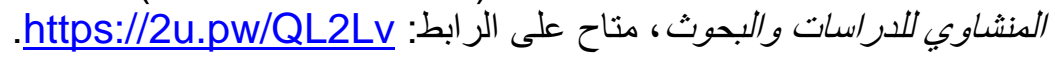

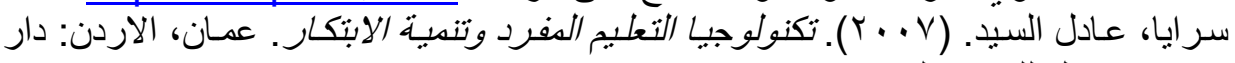

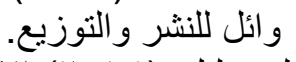

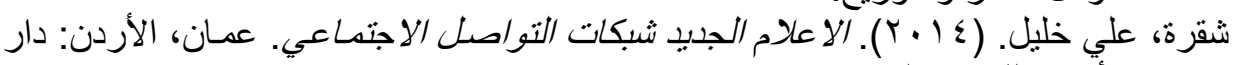
أسامة للنشر و التوزيع.

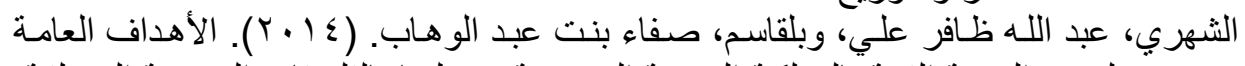

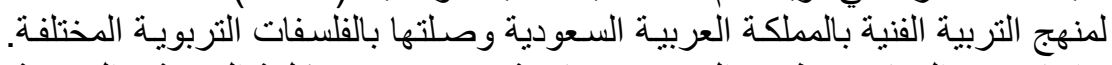

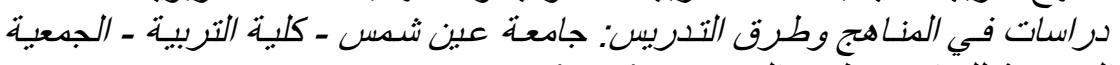

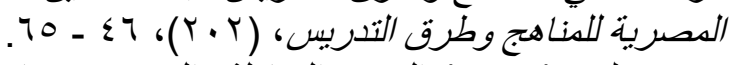

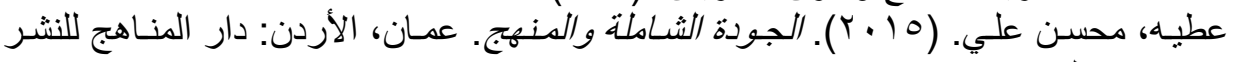
و التوزيع.

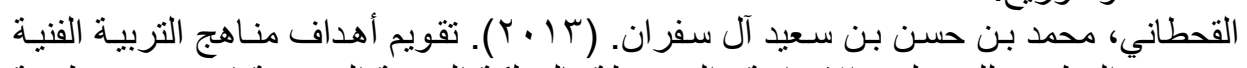

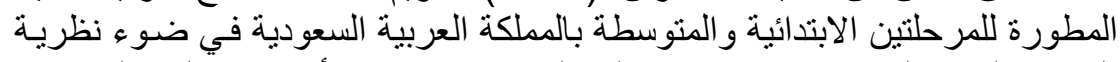

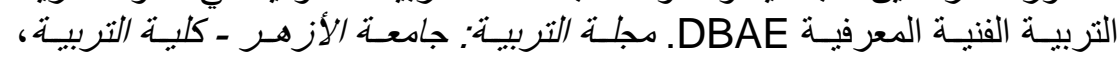
"ا

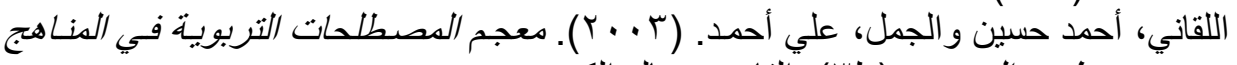

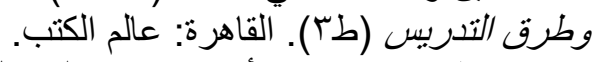

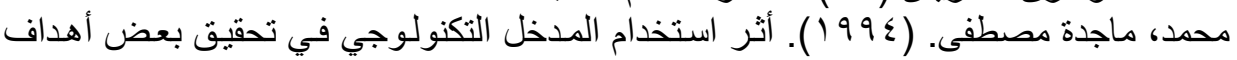

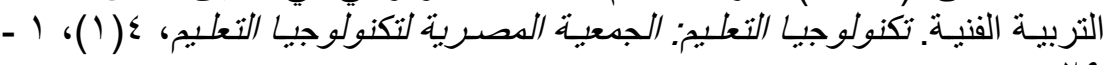
rq

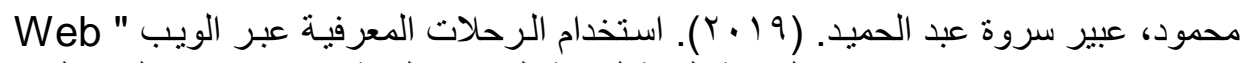
Quests

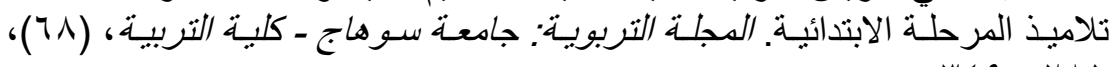

.

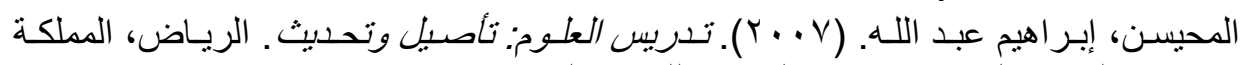

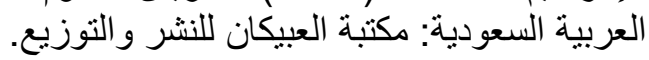

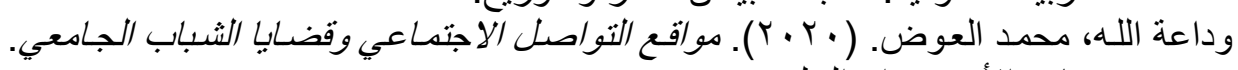
عمان، الأردن: دار الخليج. 


\section{ثانياً: المراجع الاجنبية}

DeWilde, J. (2016). Social Media as A Tool To Share Art Curriculum (Master of Science Dissertation). Illinois State University.

Enriquez, M. (2014) Students' Perception on the Effectiveness of the Use of Edmodo as a Supplementary Tool for Learning. Paper Presented at the DLSU Research Congress 2014: Philippines. De La Salle University, Manila, Philippines. March 6-8, 2014.

Ersöz, Y. \& Şad, S. (2018). Facebook as a Peer-Assessment Platform: A Case Study in Art Teacher Education Context. International Journal of Assessment Tools in Education, 5(4), 740-753.

Hankins, S. (2015). The Effects of Edmodo on Student Achievement in Middle School (PH.D dissertation), St. Thomas University.

Lassila, H. (2010). Humanitarian non-profit organizations marketing is effects on donor behavior in social media (Unpublished Master's thesis). Aalto University.

Laughton, P. (2011). The use of wikis as alternatives to learning content management systems. The Electronic Library، (2) 29, 225-235.

Liou, D. Chih, H. \& Huang, C. (2016). Investigating information sharing behavior: the mediating roles of the desire to share information in virtual communities. Information Systems and e-Business Management, 14(2), 187-216.

Lovin, E. \& lambeth, D. (2015). Effects of information and communication technology on engagement and art production for eighth-grade students. I-managers journal on school educational technology, 10 (3), pp. 13-25.

Schneider, G. (2015). Eleventh edition Electronic Commerce, CMI $\left(11^{\text {th }} \mathrm{Ed}\right)$. USA.

Sharma, K., Joshi, A. \& Sharma, H. (2016). A multi-analytical approach to predict the Facebook usage in higher education. Computers in Human Behavior, 55, 340-353. 